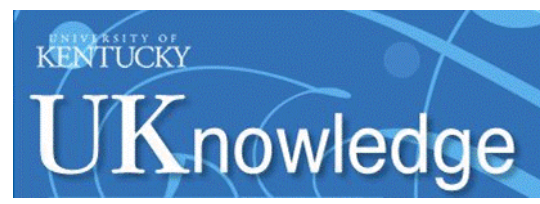

Kentucky Law Journal

2000

\title{
Law in a Shrinking World: The Interaction of Science and Technology with International Law
}

Joseph W. Dellapenna

Villanova University

Follow this and additional works at: https://uknowledge.uky.edu/klj

Part of the International Law Commons, and the Science and Technology Law Commons

Right click to open a feedback form in a new tab to let us know how this document benefits you.

\section{Recommended Citation}

Dellapenna, Joseph W. (2000) "Law in a Shrinking World: The Interaction of Science and Technology with International Law," Kentucky Law Journal: Vol. 88: Iss. 4, Article 3.

Available at: https://uknowledge.uky.edu/klj/vol88/iss4/3

This Article is brought to you for free and open access by the Law Journals at UKnowledge. It has been accepted for inclusion in Kentucky Law Journal by an authorized editor of UKnowledge. For more information, please contact UKnowledge@lsv.uky.edu. 


\title{
ARTICLES
}

\section{Law in a Shrinking World: The Interaction of Science and Technology with International Law}

\author{
BY JOSEPH W DELLAPENNA ${ }^{*}$
}

Law ts bound by its form. ${ }^{1}$

\section{INTRODUCTION}

$t$ least since the rediscovering of Roman law in eleventh-
century Italy, Western legal theory has been suffused with the
notion that law is eternal and unchanging-"right reason" as Coke expressed it. ${ }^{2}$ Ever since Oliver Wendell Holmes taught us that "law

*Professor of Law, Villanova Unıversity.B.B.A. 1965, Unıversity of Michıgan; J.D. 1968, Detroit College of Law; LL.M. 1969 (Public International \& Comparative Law), George Washıngton Unıversity; LL.M. 1974 (Environmental Law), Columbia University. Earlierversıons of this Article were delivered at a joint conference of the American Society of International Law and the Chinese Society of International Law in Beijing and at an Association of American Law Schools Annual Meeting in Washıngton, D.C.

${ }^{1}$ Ronald K.L. Collins \& David M. Skover, Paratexts, 44 STAN. L. REV 509, 509 (1992).

2 EDWARD COKE, FIRST INSTITUTE (16th ed. 1809) (1628). See also EMERICH DE VATTEL, THE LAW OF NATIONS; OR, PRINCIPLES OF THE LAW OF NATURE, APPLIED TO THE CONDUCT AND AFFAIRS OF NATIONS AND SOVEREIGNS (Joseph Chitty ed., 1883) (1763); HUGO GROTIUS, THE RIGHTS OF WAR AND PEACE 16 (A.C. Campbell ed., 1901) (1682); THOMAS HoBbES, A DIALOGUE BETWEEN A PHILOSOPHER AND A STUDENT OF THE COMMON LAWS OF ENGLAND 54-55 (J. Cropsey ed., 1971) (1681). See generally RICHARD TUCK, NATURAL RIGHTS THEORIES: THEIR ORIGIN AND DEVELOPMENT (1979); Harold J. Berman, The Origins of Histoncal Jurnsprudence: Coke, Selden, Hale, 103 YALE L.J. 1651 
is not a brooding omnipresence in the sky,"3 it has been nearly impossible to think of law as expressing logical truths or eternal verities. The life of the law really has been, as Holmes insisted on several occasions, expernence, not logic. ${ }^{4}$ No wonder Holmes concluded that "a page of history is worth a volume of logic." The problem that Holmes' insight leaves us is to relate law to contemporary experience in a world in which social reality changes at electronic speed.

One can hardly pick up a report on current legal developments without finding references to the dramatic challenges posed to law, lawyers, and legal systems by emerging technologies. ${ }^{6}$ These changes include genetic

(1994); Allen Dillard Boyer, "Understanding, Authority, and Will" Sir Edward Coke and the Elizabethan Origıns of Judicıal Revtew, 39 B.C. L. REV 43 (1997); Howard Schweber, The "Science" of Legal Science: The Model of the Natural Sciences in Nineteenth-Century American Legal Education, 17 LAW \& HIST. REV 421 (1999).

${ }^{3}$ Southern Pac. Co. v Jensen, 244 U.S. 205, 222 (1917) (Holmes, J., dissenting).

${ }^{4}$ See Oliver Wendell Holmes, JR., The COMMON LAW 1 (Mark DeWolfe Howe ed., 1963) (1944); Oliver Wendell Holmes, Jr., The Path of the Law, 10 HARV L. REV 457, 469 (1897).

${ }^{5}$ New York Trust Co. v. Eisner, 256 U.S. 345, 349 (1921).

${ }^{6}$ See Jennifer L. Alvey, Coming Soon to a Web Site Near You: Europe's Data Prvacy Protection Policy, 68 U.S.L.W 2334 (Dec. 7, 1999) [hereinafter Coming Soon]; Jennifer L. Alvey \& David Kaut, Congress Mulls Over E-Commerce Measures on Database Protections, Consumer Privacy, 68 U.S.L.W 2475 (Feb. 15, 2000); Charles Bogino, Government Agencies, Private Sector Find Ways to Target Fraud Schemes on Internet, 68 U.S.L.W 2336 (Dec. 7, 1999) [hereinafter Bogino, Fraud Schemes]; Charles Bogino, NCCUSL Electrontc Signature Measure Finds Solid Support in Maryland, Virginıa, Nebraska, 68 U.S.L.W 2486 (Feb. 22, 2000); Barry L. Brickner, Scary Things (Or How to Avold Breaching Ethlcs on the Internet), 78 MICH.B.J. 578 (June 1999); Clinton Signs Measure to Ratse Damages by 50 Percent for Copyright Infringement, 68 U.S.L.W 2360 (Dec. 21, 1999) (reporting the signing of the Digital Theft Deterrence and Copyright Damages Improvement Act); Commerce Panel Approves E-Signature Bill Seen as Overbroad by Administration, States, 68 U.S.L.W 2083 (Aug. 17, 1999); Congress Gets Bill to Continue Ban on New State Taxes on Internet Commerce, N.Y. TIMES, Feb. 4, 2000, at A20; Joyce E. Cutter, Police Fight Against Internet Crime Should Involve Consumers, Industry, 68 U.S.L.W 2415 (Jan. 18, 2000); Distance Education Conference, 30 SyllabUS, Fall 1999; Electronic Signature Bill Fails in House; Democrats Fume that Measure Was Rushed, 68 U.S.L.W 2265 (Nov 9, 1999); FDA Warns Foreign Online Drug Sites that Sales to United States May Be Illegal, 68 U.S.L.W 2473 (Feb. 15, 2000) [heremafter FDA Warns]; FDIC Offers 
engineering and other developments affecting the beginning of human life,

Guidance on Identity Theft Act; FTC Amends Rules to Implements [sic] New Law, 68 U.S.L.W 2265 (Nov. 9, 1999); Mark Felsenthal, Clinton Opposes Internet Access Taxes, Seeks 'Balance' on State Sales Taxes, 68 U.S.L.W 2487 (Feb. 22, 2000); Neil Hare, House Commerce Approves Database Bill; Concerns over Legal Publishing Put on Hold, 68 U.S.L.W 2083 (Aug. 17, 1999); ICANN Accredits WIPO to Provide Cybersquatting Dispute Resolution Services, 68 U.S.L.W 2333 (Dec. 7, 1999) [heremafter ICANN Accredits WIPO]; Lorraine McCarthy, Pennsylvania is First State to Adopt NCCUSL's Uniform E-Signature Law, 68 U.S.L.W 2358 (Dec. 21, 1999); Susan J. McGolrick, Electronic Communication Rauses Issues over Rights of Workers, Unzons, Employers, 68 U.S.L.W. 2488 (Feb. 22, 2000); James E. Morgan, Keeping Company Secrets off the Internet, LITIG. NEWS, Jan. 2000, at 4; NCCUSL Gives Final Approval to Model Laws on Electronic Signatures, Software Licenses, 68 U.S.L.W 2069 (Aug. 10, 1999); $O E C D$ Issues International Guldelines for Consumer Protection in E-Commerce, 68 U.S.L.W 2358 (Dec. 21, 1999) [hereinafter OECD Guldelines]; William G. Paul, E-Lawyering 2000, A.B.A. J., Jan. 2000, at 6; Pyramıd Schemes, High-Tech Scams Sald to Floursh in Fertile Internet Soil, 68 U.S.L.W 2415 (Jan. 18, 2000) [hereınafter Pyramid Schemes]; Hope Viner Samborn, Client on Line 1-and Online, A.B.A. J., Dec. 1999, at 79; Sentencing Guldelines Are Proposed for 'No Electronic Theft Act' Offenses, 68 U.S.L.W. 2407 (Jan. 18, 2000); Lawrence Speer, Online Bankang, Growing Sophistication of Criminals Satd to Pose Ongoing Wornes, 68 U.S.L.W 2471 (Feb. 15, 2000); Ralph A. Taylor, Jr., Lawyers May Use E-Mail for Client Confidence: Reasonable to Expect Prvacy for All Forms of E-Mail, ABA Ethics Committee Says, LITIG. NEws, July 1999, at 3; Margaret Graham Tebo, Filling ' $E$-Carts' with Caution: Business Law Section Helps Online Shoppers Avoud Problems, A.B.A. J., Jan. 2000, at 89; U.S., EUWill Not Sign Data Privacy Deal at Upcoming Summit Meeting, Offictal Says, 68 U.S.L.W. 2339 (Dec. 14, 1999) [hereinafter U.S., EU Will Not Sign]; Brian D. Wassom, A Reasonable Expectation of Privacy: Can Michigan Attorneys Safely Use Unencrypted Internet E-Mail for Confidential Communications?, 78 MiCH. B.J. 590 (June 1999); Witnesses Spar over ADA's Applicability to Internet Web Sites Durng House Hearng, 68 U.S.L.W 2485 (Feb. 22, 2000); see also Proceedings of the CanadaUnited States Law Institute Conference: The Impact of Technological Change in the Canada/U.S. Context, 25 CAN.-U.S. L.J. 1 (1999).

${ }^{7}$ See RENEe R. ANSPACH, DECIDING Who LIVES: FATEFUl ChOICES IN THE INTENSIVE-CARENURSERY (1993);ASSESSING GENETICRISKS:IMPLICATIONSFOR HEALTH AND SOCIAL POLICY (Lor1 B. Andrews et al. eds., 1994); ROBERT BLANK \& JANNA C. MERRICK, HUMAN REPRODUCTION, EMERGING TECHNOLOGIES, AND CONFLICTING RIGHTS (1995); WALTER BODMER \& ROBIN MCKIE, THE BOOK OF MAN: THE HUMAN GENOME PROJECT AND THE QUEST TO DISCOVER OUR GENETIC HERITAGE (1994); JUDITH A. BOSS, THE BIRTH LOTTERY: PRENATAL DIAGNOSIS AND SELECTIVE ABORTION (1993); MARCIA MOBILIA BOUMIL, LAW, ETHICS AND 
REPRODUCTIVE CHOICE (1994); ARTHUR CAPLAN, DuE CONSIDERATION: CONTROVERSY IN THE AGE OF MEDICAL MIRACLES (1997); THE CENTER FOR BIOETHICS AND HUMAN DIGNTTY PRESENTS GENETIC ETHICS: DO THE ENDS JUSTIFY THE GENES? (John F Kilner et al. eds., 1997); CLONING (Paul A. Winters ed., 1998); CLONING HUMAN BEINGS: REPORT AND RECOMMENDATIONS OF THE NATIONAL BIOETHICS ADVISORY COMMISSION (1997); THE CODE OF CODES: SCIENTIFIC AND SOCIAL ISSUES IN THE HUMAN GENOME PROJECT (Daniel J. Kevles \& Leroy Hood eds., 1992); COMPELLED COMPASSION: GOVERNMENT INTERVENTION IN THE TREATMENT OF CRITICALLY ILl NEWBORNS (Arthur L. Caplan et al. eds., 1992); CONTEMPORARY ISSUES IN BIOETHICS (Tom L. Beauchamp \& LeRoy Walters eds., 2d ed. 1982) (1978); ROBERT COOK-DEEGAN, THE GENE WARS: SCIENCE, POLITICS, AND THE HUMAN GENOME (1994); LYNDA Beck Fenwick, Private Choices, Public Consequences: Reproductive TECHNOLOGY AND THE NEW ETHICS OF CONCEPTION, PREGNANCY, AND FAMILY (1998); GERM-LINE INTERVENTION AND OUR RESPONSIBILITIES TO FUTURE GENERATIONS (Emmanuel Agius et al. eds., 1998); RUTH HUBBARD \& ELIJAH WALD, EXPLODING THE GENE MYTH: HOW GENETIC INFORMATION IS PRODUCED AND MANIPUlated By SCIENTISTS, Physicians, EMPloYeRs, INSURANCE COMPANIES, EDUCATORS, AND LAW ENFORCERS (1993); HUMAN CLONING (James M. Humber \& RobertF. Almeder eds., 1998); THE HUMAN GENOME PROJECT AND THE FUTURE OF HEALTH CARE(Thomas H. Murray et al. eds., 1996); JUSTICE AND THE HUMAN GENOMEPROJECT(Timothy F. Murphy \& Marc A. Lappé eds., 1994); JEROME KAGAN, THREE SEDUCTIVE IDEAS (1998); LEON R. KASS \& JAMES Q. WILSON, THE ETHICS OF HUMAN CLONING (1998); ANDREW KIMBRELL, THE HUMAN BODY SHOP• THE ENGINEERING AND MARKETING OF LIFE (1993); PHILIP KITCHER, THE LIVES TO COME: THE GENETIC REVOLUTION AND HuMAN POSSIBILITIES(1996); GINA KOLATA, CLONE: THEROADTO DOLLY, ANDTHEPATH AHEAD (1998); R.C. LEWONTIN, BIOLOGY AS IDEOLOGY: THE DOCTRINE OF DNA (1992); JEFF LYON \& PETER GORNER, ALTERED FATES: GENE THERAPY AND THE RETOOLING OF HUMAN LIFE (1995); J.K. MASON, MEDICO-LEGAL ASPECTS OF REPRODUCTION AND PARENTHOOD (1990); GLENN MCGEE, THE PERFECT BABY: APRAGMATICAPPROACHTO GENETICS (1997);DERELMORGAN, SURROGACY AND THE MORAL ECONOMY (2000); GREGORY E. PENCE, WHO'S AFRAID OF HUMAN ClonING? (1998); DIEDERIKA PRETORIUS, SURROGATE MOTHERHOOD: A WORLDWIDE VIEW OF THE ISSUES (1994); SCOTT B. RAE, THE ETHICS OF COMMERCIAL SURROGATE MOTHERHOOD (1994); HELENA RAGONE, SURROGATE MOTHERHOOD: CONCEPTION IN THE HEART (1994); REPRODUCTION, ETHICS, AND THE LAW: FEMINIST PERSPECTIVES (Joan C. Callahan ed., 1995); REPRODUCTION, TECHNOLOGY AND RIGHTS (James M. Humber \& Robert F Almeder eds., 1996); JOHN A. ROBERTSON, CHILDREN OF CHOICE: FREEDOM AND THE NEW REPRODUCTIVE TECHNOLOGIES(1994); MARTINEALIANA ROTHBLATT, UNZIPPED GENES: TAKING CHARGE OF BABY-MAKING IN THE NEW MILLENNIUM (AMERICA 
similar dramatic developments relating to the end of human life, ${ }^{8}$ and even

IN TRANSITION-RADICAL PERSPECTIVES) (1997); LeE M. SILVER, REMAKING EDEN: CLONING AND BEYOND IN A BRAVE NEW WORLD (1997); CARSON STRONG, ETHICS INREPRODUCTIVEANDPERINATAL MEDICINE: ANEWFRAMEWORK(1997); JONATHAN WEINER, TIME, LOVE, MEMORY: A GREAT BIOLOGIST AND HIS QUEST FOR THE ORIGINS OF BEHAVIOR (1999); WOMEN AND PRENATAL TESTING: FACING THE CHALLENGES OF GENETIC TECHNOLOGY (Karen H. Rothenberg \& Elizabeth J. Thomson eds., 1994); RobertF. Blomquist, Cloning Endangered Animal Species?, 32 VAL. U. L. REV 383 (1998); Cloning Symposium, 38 JURIMETRICS 1 (1997); Bernard Fredland \& Valene Epps, The Changing Families and the U.S. Immigration Laws: The Impact of Medical Reproductive Technology on the Immigration and Nationality Act's Definition of the Family, 11 GEO. IMMIGR. L.J. 429 (1997); Gilbert S. Merritt, From the Scopes Tral to the Human Genome Project: Where is Biology Taking the Law?, 67 U. CIN. L. REV 365 (1999); Mary Z.Pelias \& MargaretM. DeAngelis, The New Genetic Technologres: New Options, New Hope, and New Challenges, 45 LOY. L. REV 287 (1999); Patricia (Winnie) Roche et al., The Genetic Prvvacy Act: A Proposal for National Legislation, 37 JURIMETRICS 1 (1996); Symposium, Respecting Genetic Prvvacy, 40 JURIMETRICS 1 (1999); Lara Beth Winn, Spectal Labeling Requirements for Genetically Engineered Food: How Sound Are the Analytical Frameworks Used by FDA and Food Producers?, 54 FOOD \& DRUG L.J. 667 (1999); Susan O'Hara, Comment, The Use of Genetic Testing in the Health Insurance Industry: The Creation of a "Biologic Underclass," 22 Sw. U. L. REV 1211 (1993).

${ }^{8}$ See ROBERT L. BARRY, BREAKING THE THREAD OF LIFE: ON RATIONAL SUICIDE(1994);BASICQUESTIONS ON SUICIDE ANDEUTHANASIA. ARE THEY EVER RIGHT? (Gary P Stewart \& John Fredenc Kilner eds., 1998); MARGARET PABST BATTIN, THE LEAST WORST DEATH: ESSAYS IN BIOETHICS ON THE END OF LIFE (1994);DANW.BROCK, LIFE AND DEATH:PHILOSOPHICALESSAYS INBIOMEDICAL ETHICS (1993); GEORGE M. BURNELL, FINAL CHOICES: TO LIVE OR TO DIE IN AN Age of MEdical TeChNology (1993); Donald W COX \& RaLPH MERo, HeMlock's CuP· THE STRUGGle FOR DEATH WITH DIGNITY (1993); DAVID CUNDIFF, EUTHANASIA IS NOTTHE ANSWER:A HOSPICE PHYSICIAN'S VIEW (1992); DEATH, DYING AND THE LAW (Sheila A.M. McLean ed., 1996); EZEKIEL J. EMANUEL, THE ENDS OF HUMAN LIFE: MEDICAL ETHICS IN A LIBERAL POLITY (1994); EUTHANASIA AND OTHER MEDICAL DECISIONS CONCERNING THE END OF LIFE (P.J. Van Der Maas et al. eds., 1992); EUTHANASIA, CLINICAL PRACTICE AND THE LAW (Luke Gormally ed., 1994); EUTHANASIA EXAMINED: ETHICAL, CliniCAL, AND Legal PERSPECTIVES (John Keown ed., 1995); EUTHANASIA. OPPOSING VIEWPOINTS (Carol Wekesser ed., 1995); EUTHANASIA. THE GOOD OF THEPATIENT, THE GOODOF SOCIETY (Robert I.Misbin ed., 1992); GEREB.FULTON \& EILEEN K. METRESS, PERSPECTIVES ON DEATH AND DYING (1995); HENRY R. GLICK, THE RIGHT TO DIE: POLICY INNOVATION AND ITS CONSEQUENCES (1992); CARLOS F GOMEZ,REGULATING DEATH: THECASEOFTHENETHERLANDS (1991); 
HeRbert Hendin, SEDUCED by DEATH: Doctors, PATIENTS, AND THE DUTCH CURE (1997); JAMES M. HOEFLER, DEATHRIGHT: CULTURE, MEDICINE, POLITICS, AND THE RIGHT TO DiE (1994); HOW SHALl WE DiE?: HELPING CHRISTIANS DEBATEASSISTED SUICIDE(Sally B. Geis \&Donald E. Messers eds., 1997); DEREK HUMPHRY,FINAL EXIT: THEPRACTICALITIES OF SELF-DELIVERANCEANDASSISTED SUICIDE FOR THE DYING (1991); BRIAN P JOHNSTON, DEATH AS A SALESMAN: WHAT'S WRONG WITH ASSISTED SUICIDE (1997); F.M. KAMM, MORALITY, MORTALITY: DEATH, AND WHOM TO SAVE FROM IT (1993); KILLING AND LETTING DIE(Bonnie Steinbocked., 1980); NANCY M.P.KING, MAKING SENSEOF ADVANCE DIRECTIVES (1996); EDWARDJ. LARSON \& DARREL W. AMUNDSEN, ADIFFERENT DEATH: EUTHANASIA AND THE CHRISTIAN TRADITION (1998); WILLIAM F MAY, Testing THE MEdical Covenant: ACtive Euthanasia AND HEALTH CaRE REFORM (1996); ALAN MEISEL, THE RIGHT TO DIE (2d ed. 1995); MERCY OR MURDER?: EUTHANASIA, MORALITY AND PUBLIC POLICY (Kenneth R. Overberg ed., 1993); G. STEVENNEELEY, THECONSTITUTIONALRIGHTTOSUICIDE: ALEGAL AND PHILOSOPHICAL EXAMINATION (1994); NEW YORK STATE TASK FORCE ON LIFE AND THE LAW, WHENDEATHIS SOUGHT: ASSISTED SUICIDE AND EUTHANASIA IN THE MEDICAL CONTEXT (1994); SHERWIN B. NulaND, HOW WE DIE: REFLECTIONS ON LIFE'S FINAL CHAPTER (1993); MARGARET OTLOWSKI, VOLUNTARY EUTHANASIA AND THE COMMON LAW (1997); PHYSICIAN-ASSISTED DEATH (James M. Humber etal. eds., 1994); PHYSICIAN-ASSISTED SUICIDE(Robert F WeIr ed., 1997); WESLEY J. SMITH, FORCED EXIT: THE SLIPPERY SLOPE FROM ASSISTED SUICIDE TO LEGALIZEDMURDER(1997); PATRICIA A.TALONE, FEEDING THE DYING: RELIGION AND END-OF-LIFE DECISIONS (1996); MARILYN WEBB, THE GOODDEATH: THENEW AMERICAN SEARCH TO RESHAPE THE END OF LIFE (1997); Allen J. Bennett, When Is Medical Treatment "Futile"?, 9 ISSUES L. \& MED. 35 (1993); J.R. Curtis et al., Use of the Medical Futility Rationale in Do-Not-AttemptResuscitation Orders, 273 JAMA 124 (1995); Steven Goldberg, The Changing Face of Death: Computers, Consciousness, and Nancy Cruzan, 43 STAN. L. REV 659 (1991); Amır Halevy \& Baruch Brody, Bratn Death: Reconciling Definitions, Criterna, and Tests, 119 ANNALS INTERNAL MED. 519 (1993); James S. Reitman, The Dilemma of "Medical Futility"-A "Wisdom Model" for Decisionmaking, 12 IssUES L. \& MED. 231 (1996); George P Smith, II, Utility and the Principle of Medical Futility: Safeguarding Autonomy and the Prohibition against Cruel and Unusual Punishment, 12 J. CONTEMP HEALTH L. \& POL'Y 1 (1995); Marc D. Stern, "And You Shall Choose Life"-Futility and the Religious Duty to Preserve Life, 25 SETON HALL L. REV. 997 (1995); Robert M. Taylor \& John D. Lantos, The Politics of Medical Futility, 11 IssuEs L. \& MED. 3 (1995); Joan Teno et al., Prognosis-Based Futility Guidelines: Does Anyone Win?, 42 J. AM. GERIATRICS SOC'Y 1202 (1994); StuartJ. Youngner, Defining Death: A Superficial and Fragile Consensus, 49 ARCHIVES NEUROLOGY 570 (1992); Samantha Weyrauch, Acceptance of Whole-Brain Death Criterna for Determination of Death: $A$ Comparative Analysis of the United States and Japan, 17 UCLA PAC. BASIN L.J. 
the development of new life forms. ${ }^{9}$ Among the more pressing challenges to the legal system are the emergence of new information technologies and the resulting commercial applications. ${ }^{10}$ Countries such as China are attempting to use "e-commerce" and other forms of digital activity to leapfrog ahead in their economic development. ${ }^{11}$ The Chinese Ministry of Foreign Trade and Economic Cooperation has undertaken to require that the bidding on export commodities, the issuance of import and export quotas and licenses, and approval of all fore1gn trade and investment activities shall all be conducted on-line beginning January $1,2000 .{ }^{12}$ Some observers have even begun to speak about "e-lawyernng."13

The impacts of these developments are highly vaned. At the same time that electronic communication enables us to reach across the globe to nitiate and maintain relationships at a level never before possible, these same technologies distract us from face-to-face interaction just down the block or within our own homes..$^{14}$ We find much the same paradox at the

91 (1999).

${ }^{9}$ See Dan L. Burk, Patenting Transgenic Human Embryos: A Nonuse Cost Perspective, 30 Hous. L. REV 1597 (1993).

${ }^{10}$ See Peter H. Salus, The Net: A Brief History of Ongins, 38 JURIMETRICS 671 (1998). For the significance of this development, see, for example, JAMES BOYLE, SHAMANS, SOFTWARE, AND SPLEENS: LAW AND THE CONSTRUCTION OF THE INFORMATION SOCIETY (1996); WENDY M. GROSSMAN, NET. WARS (1997); M. ETHANKATSH,LAW INA DIGITAL WORLD 218-19 (1995) [heremafter KATSH, LAW IN A DIGITAL WORLD]; KEVIN KELLY, OUT OF CONTROL (1994); ITHIEL DE SOLA POOL, TECHNOLOGIES OF FREEDOM (1983); GENE I. ROCHLIN, TRAPPED IN THE NET: THE UNANTICIPATED CONSEQUENCES OF COMPUTERIZATION (1997); SHOSHANA ZUBOFF, IN THE AGE OF THE SMART MACHINE: THE FUTURE OF WORK AND POWER (1988); David S. Ruder, Effective International Superviston of Global Securities Markets, 14 HASTINGS INT'L \& COMP L. REV 317 (1991); Mitsuo Sato, Emerging Issues Associated with Twenty-Four Hour World Securities Trading, 14 HASTINGS INT'L \& COMP L. REV 333 (1991); Symposium, Current Issues in Electronic Data Interchange: Defining International Electrontc Commerce, 13 J.INT'LL. \& BUS. 1 (1992); Recommendation of the OECD Council Concerning Gutdelines for Consumer Protection in the Context of Electronic Commerce (visitedMay 16,2000), <http://www.oecd.org/news_and_events/release /guidelinesconsumer.pdfs

"See First On-Line Hope School, BEIING REV., Nov. 29, 1999, at30; Greeting

an E-Business Era, BEIJING REV., Dec. 6, 1999, at 12.

${ }^{12}$ See Greeting an E-Business Era, supra note 11, at 13.

${ }^{13}$ Paul, supra note 6.

${ }^{14}$ See Robert Kraut et al., Internet Paradox: A Soctal Technology That Reduces Social Involvement and Psychological Well-Being?, 53 AM. PSYCHOLOGIST 1017 
international level. The processes of technological change are feeding the consolidation of nation-states into regional entities with increasingly significant collective authority; however, this is coupled with the disintegration of nation-states-sometimes the samenation-states-along ethnic, religious, and other lines. ${ }^{15}$

Lawyers, Jurists, and scholars have begun to give a good deal of attention to the impact of such developments on particular aspects of national legal systems. On the other hand, they have given relatively little attention to the impact of these developments on the law in general, ${ }^{16}$ or on international law in particular. We do not have to rely entirely on speculation, however, to conclude that the impact is likely to be profound. Consider, for example, the expenence with admiralty law

For several thousand years, people who went to sea found themselves entirely on their own once they passed over the horizon after leaving their home port. Without long-distance communications faster than the vessel itself, there was simply no way they could contact home for advice or sustenance. This reality caused not only epic adventures such as Homer's Odyssey, but also more mundane trips in which sailors were away from home for weeks, months, or even years. ${ }^{17}$ In the course of such travels and travails, mariners often found themselves in distant lands in desperate need for provisions, rescue from peril, reparrs for their ship, medical care for

(1998); John Markoff, $A$ Newer, Lonelier Crowd Emerges in Internet Study, N.Y. TIMES, Feb. 16, 2000, at A1. See generally HOWARD RHEINGOLD, THE VIRTUAL COMMUNTYY: HOMESTEADING ON THE ELECTRONIC FRONTIER (1994); SHERRY TURKLE, LIFE ON THE SCREEN: IDENTTTY IN THE AGE OF THE INTERNET (1995).

${ }^{15}$ See BENJAMINR. BARBER, JIHADVS.MCWORLD (1996); Lynton K. Caldwell, The Geopolitics of Environmental Policy: Transnational Modification of National Sovereignty, 59 REVISTA JURIDICA U.P.R. 693 (1990); Vaclav Havel, Beyond the Nation State, 9 RESPONSIVE COMMUNITY 26 (1999); Symposium, Rethinking Nationalism and Sovereignty, 45 J. INT'L AFF 307 (1992).

${ }^{16}$ See M. ETHAN KaTSH, The ElECTRONIC MEDIA AND THE TranSFormation OF LAW (1989) [heremafter KATSH, THE ELECTRONIC MEDIA]; Lawrence Lessig, The Law of the Horse: What Cyberlaw Might Teach, 113 HARV L. REV 501 (1999); Peter W Martin, The Internet: "Full and Unfettered Access" to Law-Some Implications, 26 N. KY. L. REV 181 (1999); Pamela Samuelson, The Quest for Enabling Metaphors for Law and Lawyerng in the Information Age, 94 MicH. L. REV 2029 (1996); Eugene Volokh, Technology and the Future of Law, 47 STAN.L. REV 1375 (1995); see also ROBERT H. ANDERSONET AL., UNIVERSAL ACCESS TO E-MAIL. FEASIBILITY AND SOCIETAL IMPLICATIONS (1995).

${ }^{17}$ See Richard HENRY DaNA, JR., TWo YEARS Before tHE MAST: A PERSONAL NARRATIVE (1840); HERMAN MELVILLE, MOBY DiCK (1851). 
themselves, and other necessanes if the voyage was to be continued or completed. Maritime law developed an entirely distinct set of rules governing these needs built around the reality that the ship and her crew were on their own. The ship itself was personified, and therefore capable of suing and being sued. ${ }^{18}$ When away from their home port ships were able to borrow money or buy supplies or services on the credit of the ship without reference to the owners' consent or acquiescence. ${ }^{19}$ Ships were responsible for the maintenance and cure of their crew for the duration of the voyage and beyond. ${ }^{20}$ The master was authonzed to sacrifice part of the cargo or of the vessel itself to save the rest, with the owners of the saved portions sharng the losses with the owners of what was sacnficed. ${ }^{21} \mathrm{~A}$

${ }^{18}$ See Tucker v. Alexandroff, 183 U.S. 424, 438 (1902).

A ship is born when she is launched, and lives so long as her identity is preserved. In the baptism of launching she receives her name, and from the moment her keel touches the water she is transformed, and becomes a subject of admiralty jurisdiction. She acquires a personality of her own; becomes competent to contract, and is individually liable for her obligations, upon which she may sue in the name of her owner, and be sued in her own name. Her owner's agents may not be her agents, and her agents may not be her owner's agents. She is capable, too, of committing a tort, and is responsible in damages therefor.

Id. See generally GRANT GILMORE \& CHARLES L. BLACK, JR., THE LAW OF ADMIRALTY 589-94 (2d ed. 1975); CHRISTOPHERJ.S.HILL,MARITIMELAW95-103 (1981); THOMAS J. SCHOENBAUM, ADMIRALTY AND MARITIME LAW 33-38 (2d ed. 1994); Paul Macaruus Hebert, The Oring and Nature of Maritime Liens, 4 TUL. L. REV 381 (1930); Alex T. Howard, Jr., Personification of the Vessel: Fact or Fiction?, 21 J. MAR. L. \& COM. 319 (1990).

${ }^{19}$ See The Lottawanna, 88 U.S. (21 Wall.) 558 (1874); The General Smith, 17 U.S. (4 Wheat.) 438 (1819). See generally GILMORE \& BLACK, supra note 18, at 586-817; SCHOENBAUM, supra note 18 , at 94-179, 421-62, 675-757

${ }^{20}$ See Harden v Gordon, 11 F Cas. 480 (C.C.D. Me. 1823) (No. 6047); see also Vaughan v. Atkınson, 369 U.S. 527 (1962); Warren v. United States, 340 U.S. 523 (1951); Farrell v. United States, 336 U.S. 511 (1949); GILMORE \& BLACK, supra note 18, at 281-324; HILL, supra note 18, at 327-329; GUSTAVUS H. ROBINSON, HANDBOOK OF ADMIRALTY LAW IN THE UNITED STATES 55-92, $162-$ 233, 357-708 (1939); SCHOENBAUM, supra note 18, at 289-311.

${ }^{21}$ See Ralli v. Troop, 157 U.S. 386 (1895); Star of Hope, 76 U.S. (9 Wall.) 203 (1869); E.J. Dupont de Nemours \& Co. v. Vance, 60 U.S. (19 How.) 162 (1856); Barnard v. Adams, 51 U.S. (10 How.) 270 (1850); Vlassopoulos v. British \& Foreıgn Marine Ins. Co., I K.B. 187 (1929); see also THEDIGEST OF JUSTINIAN bk. 14, tit. 2, frag. 1 (Unıv. Penn. Press 1985) (533 C.E.); GILMORE \& BLACK, supra note 18, at 244-71, ROBINSON, supra note 20, at 764-92; SCHOENBAUM, supra note 
stranger who undertook the rescue of a ship or cargo in peril was entitled to a salvage award to compensate for the labor and nsk. ${ }^{22}$

These rules of admiralty law had no counterpart in the law applicable to land-based transactions or events. Each unique rule resulted from the ship being on its own on the high seas. With the advent of the telegraph, this independence began to change. There followed in succession regularly scheduled cargo and passenger lines, "wureless telegraphy" (radio), shup-toshore telephones, telex, telefacsimile, e-mail, and the Internet. Each of these innovations undercut the traditionally self-reliant nature of maritime voyages. Now a master can contact the owners of the vessel or the managing agents of the owners before, incurring an unscheduled major debt or before arranging the discharge of significant obligations. With the advent of rail and then air travel, the home office can send someone out to the vessel to determine many of the questions that the ships' masters formerly had to decide completely on their own. ${ }^{23}$ Such 1 s the inertia of the law, however, that most of the unique doctrines of maritime law have continued to hold sway, with only occasional departures by precedent or statute to correspond to the new realities. ${ }^{24}$ But these changes have begun,

18 , at $811-60$.

${ }^{22}$ See Merritt \& Chapman Derrick \& Wrecknng Co. v. United States, 274 U.S. 611 (1927); The Elfrida, 172 U.S. 186 (1898); The Blackwall, 77 U.S. (10 Wall.) 1 (1869); Semco Salvage \& Manne Pte. Ltd. v. Lancer Navigation Co., 1 Lloyd's Rep. 323 (1997) (H.L.). See generally GILMORE \& BLACK, supra note 18, at 53285; HILL, supra note 18, at 184-222; ROBINSON, supra note 20, at 709-63; SCHOENBAUM, supra note 18 , at 782-810.

${ }^{23}$ See May v. Hamburg-Amerikanische Packetfahrt Aktiengesellschaft, 290 U.S. 333 (1933) (noting that the head office sent a "marine superintendent" to determine whether to undertake immediate repairs or to continue a voyage without repairs).

${ }^{24}$ See Longshore and Harbor Workers' Compensation Act, 33 U.S.C. §§ 901950 (1994) (creating a workers' compensation system in response to the industralization of the loading and unloading of ships); Oil Pollution Liability and Compensation Act of 1990, 33 U.S.C. $\$ \S 2701-2761$ (1994) (revising the law relating to oil spills and other marne pollution by oil); Abandoned Shipwreck Act of 1987, 43 U.S.C. $\$ \S 2101-2106$ (1994) (establishing title in the state or federal government to all abandoned shipwrecks embedded in the continental shelfor other submerged lands of the United States as a response to the new technologies for locating long-lost ships); Admuralty and Maritime Jurisdiction Extension Act of 1948,46 U.S.C. $\$ 740$ (1994) (extending admuralty jurisdiction to injuries on land caused by a vessel); Death on the High Seas Act, 46 U.S.C. $\$ \S 761-767$ (1994) (extending admuralty jurisdiction to deaths on the high seas whether aboard ship or as a result of aenal navigation); Shıp Mortgage Act, 46 U.S.C. $\$ \S 31321-31330$ 
and are likely to continue. Admiralty is one of clearest examples of how changes in technology lead, slowly and fitfully perhaps, but inexorably, to changes in law

One other feature of maritime law is worth mentioning. Historically, maritime law was in a sense a subset of international law While one must be wary of anachronistically projecting modern concepts of sovereignty back into the past, the rules of admuralty were understood, at least since the fall of Rome, to depend on the customs of the sea and not on the authority of particular rulers. ${ }^{25}$ The nse of nation-states did lead to the "nationaliz-

(1994) (largely substituting "preferred ship mortgages" for bottomry bonds); Exxon Corp. v. Central GulfLines, Inc., 500 U.S. 603 (1991) (considerably expanding the right of agents for the owners to claim maritime liens against a ship); Executive Jet Aviation, Inc. v. Cleveland, 409 U.S. 249 (1972) (adding the requirement of a "maritime nexus" to the former pure locality test for admiralty jurisdiction over torts); Archawskı v Hanıoti, 350 U.S. 532 (1956) (recognizing a right to sue for restitution in admuralty); May, 290 U.S. at 333 (reinterpreting the owner's liability for the unseaworthiness of a vessel given the owner's reassertion of control after damage to the ship); Monica Textile Corp. v. S.S. Tana, 952 F.2d 636 (2d Cir. 1991) (holding that the contaners on a contaner ship are not "packages" under the Carnage of Goods by Sea Act's limitation of liability per package provision); Peninsular \& Onental Steam Navigation Co. v. Overseas Oil Carriers, 553 F.2d 830 (2d Cir. 1977) (recognizıng a nght to quantum meruit compensation in lieu of "live salvage"); Admiralty Symposium, 43 ST. LouIs U. L.J. 1337 (1999); Dav1d J. Bederman, Uniformity, Delegation and the Dormant Admiralty Clause, 28 J.MAR. L. \& COM. 1 (1997); William R. Casto, Additional Light on the Origins of Federal Admiralty Jurnsdiction, 31 J. MAR. L. \& COM. 143 (2000); William R. Casto, The Ongins of Federal Admiralty Jursdiction in an Age of Privateers, Smugglers, and Pirates, 37 AM. J. LEGAL Hist. 117 (1993); Jonathan M. Gutoff, Orginal Understanding and the Prvate Law Orngins of the Federal Admuralty Junsdiction: A Reply to Professor Casto, 30 J. MAR. L. \& CoM. 361 (1999); David W Robertson, Summertime Sailing and the U.S. Supreme Court: The Need for a National Admiralty Court, 29 J. MAR. L. \& COM. 275 (1998); Ernest A. Young, Preemption at Sea, 67 GEO. WASH. L. REV 273 (1999); see also George Rutherglen, The Contemporary Justification for Maritime Arrest and Attachment, 30 WM. \& MARY L. REV 541 (1989). The most extreme proposal for assimilating admiralty law to ordinary law in the United States is the recently emerged argument that the substance of admiralty law should become a matter for the states instead of the federal government as it traditionally has been.

${ }^{25}$ See WALTER AshbuRNer, THE RHOdian SEA LAW (1909); GILMORE \& BLACK, supra note 18, at 3-11, ROBINSON, supra note 20, at 1-6; Charles Sumnier Lobingier, The Maritime Law of Rome, 47 JURID. REV 1 (1935); Gordon W Paulsen, An Histoncal Overview of the Development of Uniformity in International Maritime Law, 57 TUL. L. REV 1065 (1983); Timothy J. Runyan, The Rolls of 
ing" of admiralty law, namely its reduction to the status of simply a specialized part of the law of each nation-state. ${ }^{26}$ Notwithstanding this nationalization, maritime law has remained much more internationally uniform than most other areas of law and the dominance of the field by international standards has continued to grow in the twentieth century as the world has become functionally smaller through the use of modern technology ${ }^{27}$ The question then arises: Is the growing reintegration of maritime law part of a much broader social process caused by exploding technologies that tie the world more tightly together? Are the sort of changes in the substance and style of maritime law still unique to that field, or are they harbingers of changes already beginning across the broad range of international (and national) law and practice? It is the thesis of this Article that modern technology, particularly modern information technology, is bringing about just such broad-ranging change in the substantive law, in how law is practiced, and how law is understood.

\section{A FEW WORDS ABOUT WORDS}

It is commonplace to note that the world has been getting smaller. At the same time, in terms of the volume of information available, the world

Oleron and the Admiralty Court in Fourteenth Century England, 19 AM. J. LEGAL HrST. 95 (1975).

${ }^{26}$ See DAVID W ROBERTSON, ADMIRALTY AND FEDERALISM: HISTORY AND ANALYSISOF PROBLEMS OF FEDERAL-STATERELATIONS IN THEMARITIMELAW OF THE UNITED STATES (1970); ROBINSON, supra note 20, at 7-13; John D. Kimball, Miles: “This Much and No More ，"25 J. MAR. L. \& COM. 319 (1994).

${ }^{27}$ See U.N. Convention on the Carriage of Goods by Sea (Hamburg Rules), Mar. 30, 1978, 17 I.L.M. 608 (entered into force Nov 1, 1992); Visby Amendments, Feb. 23, 1968, 6 BENEDICT ON ADMIRALTY doc. no. 1-2 (entered into force June 23, 1977) (The United States is not a party to either of these agreements, although its own Carrage of Goods by Sea Act, 46 U.S.C. $§ \S 1300$ 1315 (1994), enacted in 1936, closely follows the provisions of the Hague Rules that preceded the Hamburg Rules and Visby Amendments.). See generally Jenny Clift, Electronic Commerce: The UNCITRAL Model Law and Electronic Equivalents to Traditional Bills of Lading, 27 INT'L BUS. LAW 311 (1999); Benjamin W Yancey, The Carnage of Goods: Hague, COGSA, Visby and Hamburg, 57 TUL. L. REV 1238 (1983). See also International Convention on Salvage, Apr. 28, 1989, 20 J. MAR. L. \& COM. 589 (1989) (entered into force July 14, 1996); Convention on Limitation of Lrability for Maritime Claums, Nov 19, 1976, 16 I.L.M. 606 (entered into force Dec. 1, 1986) (the United States is not a party to this convention); Convention on the International Regulations for Preventing Collisions at Sea, Oct. 20, 1972, 28 U.S.T. 3459 (entered into force July 15, 1977); York-Antwerp Rules, 6 BENEDICT ON ADMIRALTY doc. no. 4-6 (informal agreement regarding general average adjustments). 
has grown explosively in recent decades. These changes are functions of science and technology Yet how such sweeping advances, pervasively influencing everything in our world, have affected international law has seldom been considered. I introduce this question with a few words about what I mean by the terms "international law," "science," and "technology"

International law is usually described as the law governing relations between nations, ${ }^{28}$ although the concept today includes certain aspects of the relations of individuals and collective entities across international boundanes. ${ }^{29}$ One could expend considerable effort in refining this definition, considering the role of formal norms, the need for sanctions, and the nature of relevant legal processes. I will consider some of these aspects at points later in the Article, ${ }^{30}$ but in this preliminary inquiry I am discussing international law in farly general terms that do not require much refinement. The term "international law" is herein used expansively to describe the role of law to facilitate or constrain actions by nations, corporations, individuals, and other entities when those actions transcend national borders.

Even focusing solely on the law governing relations between nations, we find that international law has undergone profound changes in its content and structure in the last seventy-five years. The relatively homogenous community that created classical international law (essentially the European states and a few other nations that shared European culture) has expanded into an increasingly heterogeneous community of nations reflecting highly varied legal traditions and disparate 1 deologies. ${ }^{31}$ The

${ }^{28}$ See IAN BROWNLIE, PRINCIPLES OF PUBLIC INTERNATIONAL LAW 58-60 (4th ed. 1990); ANTHONY CARTY, THE DECAY OF INTERNATIONAL LAW?: A REAPPRAISAL OF THE LIMITS OF LEGAL IMAGINATION IN INTERNATIONAL AFFAIRS 2,95-96 (1986); MARK W. JANIS, ANINTRODUCTIONTOINTERNATIONALLAW 2-3, 182-83 (3d ed. 1999).

${ }^{29}$ See BROWNLIE, supra note 28 , at 33, 37; INGRIDDETTER DE LUPIS, THE CONCEPT OF INTERNATIONAL LAW 23 (1987); Lung-chu Chen, Protection of Persons (Natural and Jurzdical), 14 YALE J. INT'L L. 542 (1989); M.W Janis, Individuals as Subjects of International Law, 17 CORNELL INT'L L.J. 61 (1984).

${ }^{30}$ See infra Part III.

${ }^{31}$ See Chen Tiquang, The People's Republic of Chına and Public International Law, 8 DALHOUSIE L.J. 3 (1984); Gennady M. Danilenko, The Changing Structure of the International Community: Constitutional Implications, 32 HARV. INT'L L.J. 353 (1991); Maunce Flory, Adapting International Law to the Development of the Thurd World, 26 J. AFR. L. 12 (1982); John N. Hazard, Socialism and International Public Law, 23 COLUM.J. TRANSNAT'LL. 251 (1985); Thomas W. Hoya, Marxısm 
clearest example of this change is the evolution of the United Nations from a "club" of fifty-six members, the majority of which could be described as "Western" and nearly all of which applied legal systems denved from Europe, to a forum of 188 nations representing all cultural traditions, including many nations which have returned to their indigenous legal roots in preference to European legal systems imposed by former colonial regimes. ${ }^{32}$

Although these changes are not all a direct result of scientific or technological change, one does not have to look very far for evidence of direct shifts in the law caused by scientific or technological change. Even on a field apparently so removed from science and technology as international law might appear, changes are occurring. First, one must sort out what one means by the concepts of science and technology For the purposes of this Article, I use an ordinary definition of science and technology a logically organized body of knowledge that attempts to achreve practical purposes through replicable processes. ${ }^{33}$ By this definition, science is abstract knowledge that, when combined with proper tools, becomes the technology that changes how we do things and ultimately how we live. A tool might exist for a considerable time before its applicability to a particular problem is realized, or a problem and its solution might be known theoretically for some time before the necessary tools are developed to allow for its resolution. Only when the tools and

and International Private Law, 23 COLUM. J. TRANSNAT'L L. 265 (1985); Ewell E. Murphy, Jr., The Diminishing World of Western Law, 16 TEX. INT'L L.J. 1 (1981); No-hyoung Park, The Third World as an International Legal System, 7 B.C. THIRD WORLD L.J. 37 (1987); Jeremy Thomas, International Law in Asia: An Initial Review, 13 DALHOUSIE L.J. 683 (1990); Wang Tieya, The Third World and International Law, in SELECTED ARTICLES FROM THE CHINESE YEARBOOK OF INTERNATIONAL LAW 6 (1983) [hereinafter SELECTED ARTICLES]; Surakiart Sathiratha1, Comment, An Understanding of the Relationship Between International Legal Discourse and Third World Countries, 25 HARV.INT'LL.J.395 (1984).

${ }^{32}$ See generally Konrad Ginther, Re-Defining International Law from the Point of View of Decolonisation and Development and African Regionalism, $26 \mathrm{~J}$. AFR. L. 49 (1982); John Ntambirwek1, The Developing Countres in the Evolution of an International Environmental Law, 14 HASTINGS INT'L \& COMP L. REV 905 (1991).

${ }^{33}$ See EMmanuel G. Mesthene, TeChnological Change: Its IMPaCt ON MAN AND SOCIETY 25 (1970); Joseph W Dellapenna, The History of Abortion: Technology, Morality, and Law, 40 U. PITT. L. REV 359, 362 (1979). 
necessary knowledge coexist in an organized way can we say that a particular technology has come into being. ${ }^{34}$

Unlike some popular definitions of technology, the highly general definition I propose does not limit the concept to machines, although it does posit mechanical rationality as the ideal model of both science and technology ${ }^{35}$ Such a definition has long been recognized as posing difficulties in ssolating scientific and technological processes from other forms of human activity ${ }^{36}$ This definition is neither final nor perfect, but it does provide us with an adequate concept for the purposes of this preliminary inquiry.

The suggestion that changes in science and technology will impact the socially constructed scheme of ideas known as law, or as international law, seems to smack of materialistic (specifically, technological) determinism; but it does not. Tracing the history of ideas and why they nse and fall has always been illusıve-one lawyer, William Quinn, aptly noted that "[t]racing the gradual evolution of an idea over time is like trying to lasso smoke."37 One thing, however, is certain: The prevalent ideas of the time are not simply a result of the technology that appears at a given moment. In fact, sometimes demand for a technology - a demand that might itself be driven by the prevalent ideas of the time-might drive the development of the technology ${ }^{38} \mathrm{Just}$ as there is no guarantee that the emergence of a new technology will cause most people to adopt the intellectual response that appears most natural to me, neither can anyone guarantee that demand for a new technology will be met successfully

There are those who insist that changes in the prevailing ideas of the time (the "intellectual climate") are simply the result of changing fashions in ideas. They also imagine that a "history of ideas" can ignore all but the (1934).

${ }^{34}$ See, e.g., LEWISMUMFORD, TECHNICS ANDCIVILIZATION4-6, 107-09, 139-42

${ }^{35}$ See JACQUES ELLUL, THE TECHNOLOGICAL SOCIETY 3-7, 79 (John Wilkenson trans., 1964); MUMFORD, supra note 34, at 3-12, 18-22, 31-51, 182-85, 321-33, 364-68; MAX WEBER, ECONOMY AND SOCIETY: AN OUTLINE OF INTERPRETIVE SOCIETY 65 (Guenther Roth \& Claus Wittich eds., 1978).

${ }^{36}$ See, e.g., CARL MITCHAM \& ROBERT MACKEY, JACQUES ELLUL AND THE TECHNOLOGICAL SOCIETY 102, 110-17 (1971).

${ }^{37}$ William W Quinn, Jr., Federal Acknowledgment of Amercan Indian Tribes: The Historical Development of a Legal Concept, 34 AM. J. LEGAL HIST. 331,331 (1990).

${ }^{38}$ See Steve Bickerstaff, Shackles on the Giant: How the Federal Government Created Microsoft, Personal Computers, and the Internet, 78 TEX. L. REV 1 (1999). 
changing verbal forms within a language. ${ }^{39}$ This argument is based upon a presently fashionable set of ideas know as "postmodernism." tion, the interpretive relative in the "postmodern family," many academic fields today, including law ${ }^{42}$ All knowledge, deconstruction theorists claim, is merely a social construction between the writer and (preeminently) the reader, with no possible reference to any objective, external reality ${ }^{43} \mathrm{But}$ this theory also dethrones the reader, for the reader's meaning can no more be fixed than can the author's. Logical consistency

${ }^{39}$ See MiChEL FouCAULT, ARCHAEOLOGY OF KNOWLEDGE (1972).

${ }^{40}$ See FREDERIC JAMESON, POSTMODERNISM, OR, THE CULTURAL LOGIC OF LATE CAPITALISM (1991); ChrISTOPHER LASCH, THE TRUE AND ONLY HEAVEN: PROGRESS ANDITS CRTTICS (1991); JEAN-FRANÇOIS LYOTARD, THE POST-MODERN CONDITION: A REPORT ON KNOWLEDGE (Geoff Bennington \& Brian Massum1 trans., 1984); WALTER J. ONG, INTERFACES OF THE WORD: STUDIES IN THE EVOLUTION OF CONSCIOUSNESS AND CULTURE (1977) [heremafter ONG, INTERFACES OF THE WORD]; Roberto M. Unger, Social Theory Its Situation and Its Task: A Critical Introduction (1987).

${ }^{41}$ See Allan C. Hutchunson, Identity Crisis: The Politics of Interpretation, 26 NEW ENG. L. REV 1173 (1992).

${ }^{42}$ See DeCONSTRUCTION AND THE PossibILITY OF JUSTICE (Drucilla Cornell et al. eds., 1992); David Jabban, Critical Legal Studies: A Revolution in Legal Thought, in REVOLUTIONS IN LAW AND LEGAL THOUGHT 153 (Zenon Bankowskı ed., 1991); Jacques Dernda, Force of Law: The "Mystical Foundation of Authority," 11 CARDOZO L. REV 919 (Mary Quaintance trans., 1990); Andreas Hamfelt, Formalizing Multiple Interpretation of Legal Knowledge, 3 ARTIFICIAL INTELLIGENCE \& L. 221 (1995); Leslye M. Huff, Deconstructing Sodomy, 5 AM. U. J. GENDER \& L. 553 (1997); Julie Novkov, Note, A Deconstruction of (Motherhood and a Reconstruction of Parenthood, 19 N.Y.U. REV L. \& SoC. CHANGE 155 (1991).

${ }^{43}$ See ANDREW BOYd, LIFE'S LITTLEDECONSTRUCTIONBOOK. SELF-HELPFOR THE POST-HIP (1998); HARRY M. COLLINS \& TREVOR PINCH, THE GOLEM: WHAT EVERYONE SHOULD KNOW ABOUT SCIENCE (1994); JACQUES DERRIDA, OF GRAMMATOLOGY (Gayatrı C. Spivak trans., 1977); TERRY EAGLETON, THE ILLUSIONSOF POSTMODERNISM(1996); FOUCAULT,ARCHAEOLOGY, supra note 39; LASCH, supra note 40; LYOTARD, supra note 40; PAULINE M. ROSENAU, POSTMODERNISM AND THE SOCIAL SCIENCES: INSIGHTS, INROADS, AND INSTRUSIONS (1992); UNGER, supra note 40; STEPHEN K. WHITE, POLITICAL THEORY AND POSTMODERNISM (1991); Dennis W. Arrow, Pomobabble: Postmodern Newspeak and Constitutional "Meaning" for the Uninitiated, 96 MiCH. L. REV 461 (1997); William Bywater, The Paranoia of Postmodernism, 14 PHIL. \& LIT. 79 (1990); Francis J. Mootz III, The Paranotd Style in Contemporary Legal Scholarship, 31 HOUS. L. REV 873 (1994). 
demands that there are no "subjects" to do the reading and writing. As law professor Allan Hutchinson observed, "[r]eading ends not in a final affixing of meanung, but in a temporary respite from a lasting undecidability "\$4

Hutchinson was not afraid of following this line of reasoning to its logical end. Thus, he wrote, " $[\mathrm{m}]$ eaning is not transmitted through language by independent subjects, possessed of pre-linguistic thought, but the communicating subjects are themselves constituted in and through that discourse itself." 45 Such skepticism about the possibility of truth was caught by Hutchinson's conclusion that "meaning is always to be argued for and never to be argued from." ${ }^{46}$ No wonder Jorge Lu1s Borges concluded that "[t]here is no intellectual exercise which is not, in the final analysis, useless. ${ }^{37}$ Regis Debray has observed that this particular vision is rooted in a mass media generally for whom "the objective world-the thing there is something to speak of - is what the other media are saying. $\mathrm{Be}$ it hell or heaven, from now on we are going to have to live in this haunted hall where mirrors reflect mirrors and shadows chase shadows." ${ }^{348}$ One need only recall the Marshall McLuhan scene from Woody Allen's movie Annie Hall, ${ }^{49}$ however, to see the absurdity of any such concept of solely textual meaning.

Such skeptics conclude that the only truth is there is no truth, overlooking the contradiction inherent in such a view Postmodernist skepticism

${ }^{44}$ Hutchinson, supra note 41 , at 1186.

${ }^{45} \mathrm{Id}$. at 1185 .

${ }^{46} \mathrm{Id}$. at 1188 .

${ }^{47}$ JORGE LUIS BORGES, Pierre Menard, Author of the Quixote, in LABYRINTHS; SELECTED STORIES AND OTHER WRTINGS 36, 43 (Donald A. Yates \& James E. Irby eds., 1964).

${ }^{48}$ REGIS DEBRAY, TEACHERS, WRITERS, CELEBRITIES: The INTELlECTUALS OF MODERN FRANCE 118 (David Macey trans., 1985). For a delightful skewering of the foibles of deconstruction theory in literary criticism, see Bernard Knox, Author, N.Y. REV BOOKS, Nov 16, 1995, at 16. For a feminust criticism of "postmodernism," see PAULINE JOHNSON, FEMINISM AS RADICAL HUMANISM (1994).

${ }^{49}$ ANNIE HALL (United Artists 1977). In this scene, Alvy (Woody Allen) and Annie (Diane Keeton) are waiting in line to buy tickets for a movie and they overhear a man, apparently a professor, bonng his date with a long discussion of Marshall McLuhan's theories on media. When Alvy challenges the professor's theories, the professor defends himself by informing Alvy that he teaches communications at Columbia University. Alvy steps out of line and returns almost instantly, with the real Marshall McLuhan who promptly demolishes the astounded professor's theores. Alvy turns to the camera and comments, "Boy, if only life were like this. "Id. 
renders any possibility of generalization impossible - even generalizations that would destabilize the very social order that the postmodernists are intent on destabilizing. The impossibility of generalizing makes each example wholly particular, from which no lessons can be gleaned. ${ }^{50}$ For example, just because not every woman is either Catharine MacKinnon or Phyllis Schafly, does not mean that we cannot say anything meaningful about women in general. ${ }^{51}$ Nor can someone who chooses to continue living simply jump out a seventh-story window because she has decided that height is a social construction..$^{52}$ As David Hume noted some two centuries ago, humans simply are not capable of such comprehensive doubt as deconstruction expresses and as jumping out a window would require-despite posturng to the contrary ${ }^{53}$

In fact, much the same holds true for texts. A contrary conclusion could only lead to the premise that texts have no meaning at all apart from what a reader chooses to impose on them. ${ }^{54}$ Yet we all convey meaning through language, and through texts. Just because we do not communicate perfectly, does not mean that all communication fails. ${ }^{55}$ Do we really find such expressions as "keep off the grass" or "drop dead" confusing? ${ }^{56}$ If it were otherwise, why would we bother putting anything on paper beyond the single word "TEXT" and allow the reader to put into it anything the reader likes, from the Bible to Shakespeare, from Henry James, James Joyce, or Alice Walker—or Jacqueline Susan. ${ }^{57}$ (How we would magine

${ }^{50}$ See Susan Bordo, Feminism, Postmodernism, and Gender-Scepticism, in FEMINISM/POSTMODERNISM 131, 151 (Linda Nicholson ed., 1989); Judith Butler, Gender Trouble, Feminist Theory, and Psychoanalytic Discourse, in FEMINISM/ POSTMODERNISM, supra, at 324, 327; Edward L. Rubin, The New Legal Process, the Synthests of Discourse, and the Microanalysis of Institutions, 109 HARV L. REV 1393, 1401 (1996).

SI I am indebted to Allan Hutchinson, a committed postmodernist, for this observation. See Hutchinson, supra note 41, at 1197

52 See James Allan, A Doubter's Guzde to Law and Natural Right, 28 VICTORIA U. WELLINGTON L. REV 243, 246 (1998).

${ }^{53}$ See DAVID HUME, A TREATISE OF HUMAN NATURE bk. 1 (1739).

${ }^{54}$ See Roland BARTHES, IMAGE-MuSiC-TEXT 142 (Stephen Heath trans., 1978).

${ }^{55}$ See Denis J. Brion, Performing the Constitution, 49 WASH. \& LEE L. REV 293, 310 (1992).

${ }^{56}$ See Gerald Graff, "Keep Off the Grass," "Drop Dead, " and Other Indeterminacies: A Response to Sanford Levinson, 60 TEX. L. REV 405 (1982).

${ }^{57}$ See Don Herzog, As Many As Six Impossible Things Before Breakfast, 75 CAL. L. REV 609, 629 (1987). 
these authors if all they had produced were that one single word is another question.)

The belief that all knowledge is socially constructed, or even that law 1s simply a social construction that is ultimately arbitrary, does not explain why one idea generally comes to be seen as "better" than another, or why "new" theories succeed in displacing earlier theories or why they do so at a particular time. In many contexts, theories that today have become cornerstones of our notions of reality (for example, the atomic theory of matter), have been around for decades or centunes. Nevertheless, they were onginally seen as marginalized or irrelevant, until the theory displaced the previously dominant theory ${ }^{58} \mathrm{My}$ resolution of the tension between the role of 1deas and of material conditions draws on the early work of Thomas Kuhn, a leading, albeit controversial, historian of science. ${ }^{59}$

Many scholars read Kuhn as arguing that scientific models are arbitrary because any particular scientific model (in Kuhn's snob word, a "paradigm") neither resolves all questions about the relevant experimental data addressed, nor can claim to be, in any ultimate sense, true. ${ }^{60}$ Those readers would have us conclude that, objectively, one scientific paradigm is as good as another. Kuhn himself seems to have supported this notion in some of his later writings. ${ }^{11}$ This reading of Kuhn supports the notion that

${ }^{58}$ See generally Thomas S. Kuhn, The Structure of Sclentific Revolutions, in INTERNATIONAL ENCYCLOPEDIA OF UNIFIED SCIENCE (Otto Neurath ed., $2 \mathrm{~d}$ ed. 1970) (1962).

${ }^{59}$ See $\imath$ d., see also THOMAS S. KUHN, THE ESSENTIAL TENSION: SELECTED STUDIES IN SCIENTIFIC TRADITION AND CHANGE 270-92 (1977) [hereinafter KUHN, ESSENTIAL TENSION]. For a simplistic but extended attempt to apply Kuhn's analysis to legal change, see Edward J. Conry \& Caryn L. Beck-Dudley, MetaJurusprudence: A Paradigm for Legal Studies, 33 AM. Bus. L.J. 691 (1996).

${ }^{60}$ See Paul Feyerabend, Consolations for the Spectalist, in CRITICISM AND THE GROWTH OF KNOWLEDGE 197, 214-15 (Imre Lakatos \& Alan Musgrave eds., 1970); SHEILA JASANOFF, THE FIFTH BRANCH: SCIENCE ADVISERS AS POLICYMAKERS 12-14 (1990); G. EDWARD WHITE, INTERVENTION AND DETACHMENT: ESSAYS IN LEGAL HISTORY AND JURISPRUDENCE 23-27, 35-36 (1994); D. Marvin Jones, The Death of the Employer Image, Text, and Title VII, 45 VAND. L. REV 349, 359-66 (1992); Duncan Kennedy, The Structure of Blackstone's Commentartes, 28 BUFF L .REV 205, 213-17 (1980); Jeanne L. Schroeder, Subject: Object, 47 U.MIAMIL.REV 1, 20 n.44, 23-24, 26 n.65, 77-79, 91-93 (1992); Peter H. Schuck, Multi-Culturalism Redux: Sclence, Law, and Politics, 11 YALE L. \& POL'Y REV 1, 15-18, 37-38 (1993).

${ }^{61}$ See Thomas S. Kuhn, Reflections on My Critics, in CRITICISM AND THE GROWTH OF KNOWLEDGE, supra note 60, at 231, 260-65. 
changes in society and changes in science, are purely functions of intellectual fashion rather than a response to anything outside of capricious minds embracing new ideas.

Read in this way, Kuhn deserves the harsh criticism sometimes directed toward his work, particularly by scientists and other philosophers or histonans of science. ${ }^{62}$ However, Kuhn does not have to be read in this fashion. Following some aspects of Kuhn's thinking shows that the material conditions of the time shape intellectual fashions at least as much as intellectual fashions shape material conditions. ${ }^{63}$ As Peter Berger pounted out, once a tool has been invented its needs tend to dominate those who use it:

Once produced, the tool has a being of its own that cannot be readily changed by those who employ it. Indeed the tool may even force the logic of its being upon its users, sometimes in a way that may not be particularly agreeable to them. For instance a plow, though obviously a human product, may compel its users to arrange their agncultural activity, and perhaps also other parts of ther lives, in a way that conforms to its own logic, and they may have been neither intended nor foreseen by those who onginally devised it. The same objectivity characternzes the non-material elements of culture as well. Man [sic] invents a language and then finds that both his speaking and his thinking are dominated by its grammar. ${ }^{64}$

Matenal conditions do not affect social and individual attitudes in a simple, deterministic way The materal conditions of life pose certain core problems to those living at the time just as particular experimental data

${ }^{62}$ See Imre Lakatos, Falsification and the Methodology of Scientific Research Programmes, in CRITICISM AND THE GROWTH OF KNOWLEDGE, supra note 60, at 91, 177-80; Thomas Nagel, The Sleep of Reason-Fashionable Nonsense: Postmodern Philosophers' Abuse of Sclence, THE NEW REP., Oct. 12, 1998, at 32, 35-36; Karl Popper, Normal Science and Its Dangers, in CRITICISM AND THE GROWTH OF KNOWLEDGE, supra note 60, at 51.

${ }^{63}$ See KUHN, EsSENTIAL TENSION, supra note 59, at 261. For examples of historians who have drawn similar conclusions, see JARED MASON DIAMOND, GUNS, GERMS, AND STEEL. THE FATES OF HUMAN SOCIETIES (1997); LINDA GORDON, WOMAN'S BODY, WOMAN'S RIGHT: BIRTH CONTROL IN AMERICA 18082, 189-91 (1977); Daniel T. Rodgers, Republicanism: The Career of a Concept, 79 J. AM. HIST. 11, 20-30 (1992).

${ }^{64}$ Peter L. Berger, The SaCred Canopy• Elements of a Sociological THEORY OF RELIGION 9 (1967). 
pose certain core problems to scientists working with the data. Intellectual paradigms will be constructed to address core problems and succeed in gaining adherents if the paradigm appears to resolve the core problems, even while leaving unresolved (or perhaps exacerbating) problems that are seen as on the periphery ${ }^{65}$ The new intellectual paradigm shapes further thought and brings about at least some changes in future material conditions. In a sort of interactive loop the changed material conditions - whatever the source of those changes-alters the core problems of the society and thus leads to the nse of new intellectual paradigms. ${ }^{66}$ Law professor David Luban has suggested an example that perhaps sets the distinction in clearer perspective:

Causal explanations are standpoint-and-purpose-relative. A surge of electricity through a wire will not cause it to ignite unless oxygen is present, so in one sense the presence of oxygen has just as much a clam as the surge of electricity to be the cause of the wre's 1gniting. The electricity, like the oxygen and other factors such as the wire's conductivity, are contributing conditions of the wire 1gniting. Ordinarily, however, we would say that it was the electricity, not the oxygen, that caused the wire to 1gnite: if, in answer to the question "What made the wire burn up?," someone replied "The arr did it," we would treat the reply as a wisecrack. All contributing conditions are created equal, but for practical explanatory purposes we must mevitably distingush background conditions (such as the presence of oxygen) from foreground conditions, such as the surge of electricity. The ones in which we are interested move to the foreground, and precisely these we dignify by calling them causes of events. ${ }^{67}$

Luban appears to consider the choice of foreground and background factors to be a matter of mere preference rather than a result of a particular fit

${ }^{65}$ See WHITE, supra note 60, at 41-43; Feyerabend, supra note 60, at 220; Lakatos, supra note 62, at 116-18; Schroeder, supra note 60.

${ }^{66} \mathrm{See}$ J. HERBIE DIFONZO, BENEATH THE FAULT LINE: THE PopUlaR AND LEGAL CULTURE OF DIVORCE IN TWENTIETH-CENTURY AMERICA 1-12 (1997); $c f$. RAYMOND G. DEVRIES, MAKING MIDWIVES LEGAL. CHILDBIRTH, MEDICINE, AND THE LAW 9-16 (2d ed. 1996) (argung that law and medicine form an interactive system in which each affects the other).

${ }^{67}$ David Luban, Getting the Word, 91 MICH. L. REV 1247, 1259 (1993) (emphasis in onginal). Luban denves this example from two sources: H.L.A.HART \& TONY HONORÉ, CAUSATION IN THE LAW 34-35 (2d ed. 1985) and J.L. Mackie, Causes and Conditions, 2 AM.PHIL.Q. 245 (1965); see also JOEL FEINBERG, HARM TO OTHERS 177 (1984). 
between an aspect of the "contributing conditions" and the event that leads most people to ascribe that aspect as the cause. He fails to note that oxygen is seen as a background condition precisely because it is always present, while electricity is seen as the "cause" because it is a new vanable, the introduction of which precipitates the fire. While claims about the causation of any complex human action will remain controversial, to insist that only socially constructed attitudes count is arbitrary and shortsighted.

Changes in science and technology have transformative power because the prevalent ideas in science and technology today are central to the matenal conditions in which they anse. Prevailing ideas do not change simply because someone has a catchy way of expressing a new idea which is somehow imposed on all society through legal institutions. Even postmodernism can be understood as an effort to reflect in the social sciences and the humanities (including law) the dramatic intellectual changes wrought by the theory of relativity and the Heisenberg uncertainty principle. ${ }^{68}$ These theories, themselves scientific, are rooted in the problems

${ }^{68}$ See Laurence H. Tribe, The Curvature of Constitutional Space: What Lawyers Can Learn from Modern Physics, 103 HARV L. REV 1, 14-15, 31 (1989); R. George Wright, Should the Law Reflect the World? - Lessons for Legal Theory from Quantum Mechanics, 18 FLA. ST. U. L. REV 855 (1991). See generally JOHN M. CONLEY \& WILLIAM M. O'BARR, RULES VERSUS RELATIONSHIPS: THE ETHNOGRAPHY OF LEGAL DISCOURSE (1990); ALLAN C. HUTCHINSON, DWELLING ON THE THRESHOLD: CRITICAL ESSAYS ON MODERN LEGAL THOUGHT (1988); INTERPRETING LAW AND LITERATURE: A HERMENEUTIC READER (Sanford Levinson \& Steven Mailloux eds., 1988); MARK KELMAN, A GUIDE TO CRITICAL LEGAL STUDIES (1987); DUNCAN KENNEDY, LEGAL EDUCATION AND THE REPRODUCTION OF HIERARCHY: A POLEMIC AGAINST THE SYSTEM (1983); THE POLITICS OF LAW· A PROGRESSIVE CRITIQUE (David Kairys ed., 1982); JAMES B. WHITE, JUSTICE AS TRANSLATION: ANESSAY IN CULTURAL AND LEGAL CRITICISM (1990) [hereinafter WHITE, JUSTICE AS TRANSLATION]; JAMES B. WHITE, WHEN WORDS LOSE THEIR MEANING: CONSTITUTIONS AND RECONSTITUTIONS OF LANGUAGE, CHARACTER AND COMMUNITY (1984); J.M. Balkın, Deconstructive Practice and Legal Theory, 96 YALE L.J. 743 (1987); Jeffrey M. Blum, Critical Legal Studies and the Rule of Law, 38 BUFF. L. REV. 59 (1990); Robert M. Cover, Forword: Nomos and Narrative, 97 HARV L. REV 4 (1983); Robert W Gordon, Unfreezing Legal Reality: Critical Approaches to Law, 15 FLA. ST.U.L.REV 195 (1987); Alan Hunt, The Big Fear Law Confronts Postmodernism, 35 MCGILLL.J. 507 (1990); Steven D. Smith, Law Without Mind, 88 MICH. L. REV 104 (1989); Philip Soper, Legal Theory and the Claim of Authority, 18 PHIL. \& PUB. AFF. 209 (1989); Ruchard Weisberg, Coming of Age Some More: 'Law and Literature' Beyond the Cradle, 13 Nova L. REV 107 (1988); Robın L. West, Adjudication is Not Interpretation: Some Reservations About the Law-As-Literature Movement, 54 TENN. L. REV. 203 (1987); Robin L. West, Jurzsprudence and Gender, 55 U. CHI. 
confronted when the available technologies turned up new core problems that old science simply no longer adequately addressed.

Law is easier to conceive as simply a social construction than many other intellectual fields. Yet for law as well, the maternal conditions pose core problems that legal systems must resolve, and constrain how those problems can be resolved. ${ }^{69} \mathrm{~A}$ legal solution, in order to be stable, must to a considerable extent reflect the sense of the community-a sense that in turn is responding to the material conditions of the time and place. Even revisionist legal historian Robert Gordon who, while arguing that we should leave space for alternative voices from the past, has recognized that law represents a particular vision of social reality, a vision that was not imposed on the dissenters. The past, Gordon wrote, represents

not on a single developmental path but on multiple trajectories of possibility, the path actually chosen being chosen not because it had to be but because the people pushing for alternatives were weaker and lost out in their struggle or because both winners and losers shared a common consciousness that set the agenda for all of them, highlighting some possibilities and suppressing some others completely ${ }^{70}$

Turning back to international legal processes, we find the idea that science and technology has had a profound impact on international law has seldom been recognized or even considered. One will find little direct acknowledgement of such effects in the source matenals of international law ${ }^{71}$ International law, in fact, has had rather little to say about science or technology except for a few treaties regulating the use of technologies, ${ }^{72}$

L. REV 1 (1988) [heremafter West, Jurnsprudence and Gender].

${ }^{69}$ Recall the brief history of admuralty and maritime law in the introduction to this Article, supra notes 17-27

${ }^{70}$ Robert W Gordon, Critical Legal Histornes, 36 STAN. L. REV 57, 112 (1984).

${ }^{11}$ But see John K. Gamble, International Law and the Information Age, 17 MiCH.J. INT'LL. 747 (1996); Manfred Lachs, Views From the Bench: Thoughts on Science, Technology and World Law, 86 AM. J. INT'L L. 673 (1992).

${ }^{72}$ See Convention on International Liability for Damage Caused by Space Objects, Mar. 29, 1972, 24 U.S.T. 2389 [heremafter Space Objects Convention]; Agreement Relating to the International Telecommunications Satellite Organization, Aug. 20, 1971,23 U.S.T. 3813 [hereinafter Intelsat Agreement]; SeaBed Arms Control Treaty, Feb. 11, 1971, 23 U.S.T. 701 [hereinafter Sea-Bed Treaty]; Treaty on the Non-Proliferation of Nuclear Weapons, July 1, 1968, 21 
guarantees of freedom of scientific research in the high seas, ${ }^{73}$ on Antarctica, ${ }^{74}$ and in outer space, ${ }^{75}$ and efforts to secure protection for intellectual property ${ }^{76}$ Science and technology have changed the ends pursued by international law, the means available to international law for pursuing those ends, and the nature and structure of international law itself. We shall have to consider each of these changes if we are to begin to understand how science and technology are impacting upon international legal processes.

\section{ALTERING ENDS AND MEANS}

I begin to examine the impact of science and technology on international law by summanzing the ways in which developments have created an undeniable need for international collaboration where formerly each nation might have felt itself autonomous. As a result of changes, states, international organizations, multinational corporations, and individuals have all recognized new purposes and goals in their legal interactions on the international plain. In short, they have had to learn to cope with new ends for international legal processes. Following our brief look at the changed ends of international law, I provide a brief summary of the ways in which science and technology have developed new means for creating, implementing, and enforcing both older international norms and newer norms.

U.S.T. 483 [hereinafter Non-Proliferation Treaty]; Treaty Banning Nuclear Weapon Tests in the Atmosphere, in Outer Space and under Water, Aug. 5, 1963, 14 U.S.T. 1313 [hereinafter Partial Test Ban Treaty]; Statute of the International Atomic Energy Agency, Oct. 26, 1956, 8 U.S.T. 1093 [heremafter IAEA Statute]; Chicago Convention on International Civil Aviation, Dec. 7, 1944, 61 Stat. 1180 [hereinafter ICAO Convention].

${ }^{73}$ See United Nations Convention on the Law of the Sea, Dec. 10, 1982, arts. 87(1)(f), 143, 238-65, 21 I.L.M. 1261.

${ }^{74}$ See Antarctic Treaty, Dec. 1, 1959, arts. I, II, 12 U.S.T. 794.

${ }^{75}$ See Treaty on Principles Governing the Activities of States in the Exploration and Use of Outer Space, Including the Moon and Other Celestial Bodies, Jan. 27, 1967, arts. I, IX, 18 U.S.T. 2410 [hereinafter Outer Space Treaty].

${ }^{76}$ See Universal Copynght Convention, July 24, 1971, 25 U.S.T. 1341 [hereinafter The Berne Convention]; Patent Cooperation Treaty, June 19, 1970, 28 U.S.T.7645. See generally Symposum, Fundamentals of International Copyright: The Impact of Berne, 8 CARDOZO ARTS \& ENT. L.J. 1 (1989). 


\section{A. Ends Alteration}

Examples abound of problems created by science and technology that cannot be addressed adequately within the confines of a single country where formerly there was no need for international cooperation. For example, concern to prevent the increasingly horrible reality of war using modern technology began before anyone ever dreamed of nuclear fission or fusion, ${ }^{77}$ yet, these developments dramatically changed the nature of the problems confronting the international community Since 1945, the international community has had to struggle with controlling the development,${ }^{78}$ proliferation, ${ }^{79}$ and use of nuclear or thermonuclear weapons, ${ }^{80}$ as

${ }^{77}$ See Treaty Providing for the Renuncration of War as an Instrument of National Policy, Aug. 27, 1928, 46 Stat. 2343 [hereinafter Kellogg-Brand Pact]; Convention (IV) Respecting the Laws and Customs of War on Land, Oct. 18, 1907, 36 Stat. 2277

${ }^{78}$ See Partial Test Ban Treaty, supra note 72; Nuclear Tests (Austl. v. Fr.), 1973 I.C.J. 99 (Interm Protection Order of June 22), 1974 I.C.J. 253 (Judgment of Dec. 20); Shumoda v. Japanese Government, 8 JAP ANN. INT'L L. 212 (Tokyo Dist. Ct. 1964); George D. Haimbaugh, Ir., Protecting the Seas from Nuclear Pollution, 33 S.C. L. REV 197 (1981); Myres S. McDougal \& Norbert A. Schle1, The Hydrogen Bomb Tests in Perspective: Lawful Measures for Security, 64 YALE L.J. 648 (1955).

${ }^{79}$ See Non-Proliferation Treaty, supra note 72; Treaty on the Limitation of Anti-Ballistic Missile Systems, May 26, 1972, U.S.-U.S.S.R., 23 U.S.T. 3435 [herennafter ABM Treaty]; Jack H. McCall, Jr., "The Inexorable Advance of Technology"' Amencan and International Efforts to Curb Missile Proliferation, 32 JURIMETRICS 387 (1992); John N. O'Brien, International Auspices for the Storage of Spent Nuclear Fuel as a Nonproliferation Measure, 21 NAT. RESOURCES J. 857 (1981).

${ }^{80}$ See Agreement on Measures to Reduce the Risk of Nuclear War Outbreak, Sept. 30, 1971, U.S.-U.S.S.R., 22 U.S.T. 1590; Sea-Bed Treaty, supra note 72; Declaration on the Prohibition of the Use of Nuclear and Thermo-Nuclear Weapons, G.A. Res. 1653, U.N. GAOR, 16th Sess., Supp. No. 17, at 4, U.N. Doc. A/5100 (1962); RICHARD A. FALK ET AL., NUCLEAR WEAPONS AND INTERNATIONALLAW (1981); ELLIOTT L. MEYROWITZ, PROHIBITION OFNUCLEAR WEAPONS:THERELEVANCEOFINTERNATIONAL LAW (1990); JULIUS STONE, LEGAL CONTROLS OF INTERNATIONAL CONFLICT: A TREATISE ON THE DYNAMICS OF DISPUTES-AND WAR-LAW 324-48 (1954); Louis RenéBeres, Confronting Nuclear Terrorism, 14 HASTINGS INT'L \& COMP L. REV 129 (1990). 
well as with the development and utilization of peaceful uses of atomic energy $^{81}$ and the safe disposal of nuclear wastes. ${ }^{82}$

Almost as dramatic as nuclear problems are the emerging problems of managing activities in outer space. ${ }^{83}$ Less emotive, but more immedi-

${ }^{81}$ See IAEA Statute, supra note 72; PAUL C. SZASZ, THE LAW AND PRACTICE OF THE INTERNATIONAL ATOMIC ENERGY AGENCY (1970); Ann Voorhees Billingsley, Private Party Protection Against Transnational Radiation Pollution Through Compulsory Arbitration: A Proposal, 14 CASE W RES. J. INT'L L. 339 (1982); Burrus M. Carnahan, Protecting Nuclear Facilities from Military Attack: Prospects after the Gulf War, 86 AM. J. INT'L L. 524 (1992); Michael S. Straubel, Space Borne Nuclear Power Sources-The Status of Their Regulation, 20 VAL.U. L. REV 187 (1986); Judith A. Perritano, Note, International Liability for Nuclear Pollution, 11 SUFFOLK TRANSNAT'L L. REV 75 (1987); William J. Broad, Quest for Fusion Power Is Going International, N.Y TIMES, July 28, 1992, at C2.

${ }^{82}$ Consider some states practice of placıng nuclear waste facilities close to an international border in order that any resulting water pollution will flow across the border, thereby removing one basis for objections to the placement within the upper basin state. See Joaquim Evaristo da Silva, Transboundary Water Resources Conflicts in the Iberian Peninsula 1, 4-6 (1987) (unpublished monograph, on file with author). The European Parliament has adopted a non-binding resolution to prohibit the placing of such facilities within 100 kilometers of any international border. Id. at 5. See generally Daniel P Finn, Ocean Disposal of Radioactive Wastes: The Obligation of International Cooperation to Protect the-Marne Environment, 21 VA. J. INT'L L. 621 (1981); Günther Handl, Managing Nuclear Wastes: The International Connection, 21 NAT. RESOURCES J. 267 (1981); George C. Kasoulides, State Responsibility and Assessment of Liability for Damage Resulting from Dumping Operations, 26 SANDIEGo L. REV 497 (1989); Robert A. Kaplan, Comment, Into the Abyss: International Regulation of Subseabed Nuclear Waste Disposal, 139 U. PA. L. REV 769 (1991); David G. Spak, Comment, The Need for a Ban on All Radioactive Waste Disposal in the Ocean, 7 NW. J. INT'LL. \& BUS. 803 (1986).

${ }^{83}$ See Agreement Concerning Cooperation in the Exploration and Use of Outer Space for Peaceful Purposes, Apr. 15, 1987, U.S.-U.S.S.R., T.I.A.S. No. 11433; Outer Space Treaty, supra note 75; BROWNLIE, supra note 28, at 267-71; CARLQ. CHRISTOL, THE MODERN INTERNATIONAL LAW OF OUTER SPACE (1982); J.E.S. FAWCETT, OUTER SPACE:NEW CHALLENGES TOLAW ANDPOLICY (1985); ANDREW J. YOUNG, LAW AND POLICY IN THE SPACE STATIONS' ERA (1989); Rene Côté, La mutation du régime jurtdique des espaces en droit international public et le rôle des intrants technologzques, 27 CAN. Y.B. INT'L L. 113 (1989); Stephen Gorove, Legal and Policy Issues of the Aerospace Plane, 16 J. SPACE L. 147 (1988); Roy Carleton Howell, International Telecommunications and the Law: The Creation of Pan African Satellites, 31 How. L.J. 575 (1988); Edward G. Lee \& D.W Sproule, Liability for Damage Caused by Space Debrzs: The Cosmos 954 Claim, 26 CAN. 
ately affecting people's lives, has been the highly effective regime for the cooperative management of activities in the atmosphere. ${ }^{84}$ Recent attention has turned to providing security for digital systems in the face of hostile actions by foreign states or even major criminal activities. ${ }^{85}$

Similarly likely to affect people's lives, but with even less public notice, is the increasing globalization of markets and enterprises made possible by modern communication technologies. Indeed, the regulation of communication technologies has become an arena of international contention. ${ }^{86}$ Even something as simple as determining the names to be

Y.B. INT'L L. 273 (1988); Steven A. Levy, INTELSAT. Technology, Politics and the Transformation of a Regime, 29 INT'L ORG. 655 (1975); Ni Zhengyu, On Definition and Delimitation of Outer Space, in SELECTEDARTICLES, supra note 31, at 106; David Enrico Reibel, Environmental Regulation of Space Activity: The Case of Orbital Debrzs, 10 STAN. ENVTL. L.J. 97 (1991); Martin A. Rothblatt, New Regulatory Ideas and Concepts in Space Telecommunications, 20 J. SPACE L. 27 (1992); Paula K. Speck, Comment, Competition in International Satellite Telecommunications: Alternative Avenues, 20 TEX. INT'L L.J. 517 (1985); Alan Michael Solana, Note, The International Telecommunication Union and the Third World's Quest for Equitable Access to the Orbit/Spectrum Resource, 4 B.C. THIRD WORLD L.J. 183 (1984); Ole Varmer, Note, The Thurd World's Search for Equitable Access to the Geostationary Satellite Orbit, 11 ILSA J. INT'L L. 175 (1987).

${ }^{84}$ See ICAO Convention, supra note 72; see also Convention for the Suppression of Unlawful Acts Against the Safety of Civil Aviation, Sept. 23, 1971, 24 U.S.T. 565 (entered into force Jan. 26, 1973); Convention for the Suppression of Unlawful Seizure of Aircraft, Dec. 16, 1970, 22 U.S.T. 1641 (entered into force Oct. 14, 1971); Tokyo Convention on Offences and Certain Other Acts Committed on Board Aurcraft, Sept. 14, 1963, 20 U.S.T. 2941 (entered into force Dec. 4, 1969). See generally Jeswald W Salacuse, The Little Prince and the Businessman: Conflicts and Tensions in Public International Alr Law, 45 J. AIR L. \& COM. 807 (1980); Edith Brown We1ss, International Responses to Weather Modification, 29 INT'LORG. 805 (1975); Elizabeth Cuadra, Note, Air Defense Identification Zones: Creeping Jurnsdiction in the Airspace, 18 VA. J. INT'L L. 485 (1978).

${ }^{85}$ See Kent Alexander \& Scott Charney, Computer Crime, 45 EMORY L.J. 931 (1996); Nicolas Laos, Information Warfare and Low Intensity Operations, 4 PERCEPTIONS No. 2, at 174 (June-Aug. 1999); Edward M. Wise, Crimınal Law: Sex, Crime, and Cyberspace, 43 WAYNEL. REV 137 (1996); Howard L. Steele, Jr., Comment, The Web that Binds Us All: The Future Legal Environment of the Internet, 19 HOUS. J. INT'L L. 495 (1997).

${ }^{86}$ See Bernstein v. United States Dep't of State, 922 F Supp. 1426 (N.D. Cal. 1996) (vording regulations requiring a license to export encryption codes as a prior restraint of speech); Draft Convention on Freedom of Information, U.N. GAOR, 
26th Sess., Agenda Item 51 Annexes (No. 51) 1, U.N. Doc. A/8340 (1971); Resolution on Information Facilities in Under-Developed Regions of the World, G.A. Res. 633, U.N. GAOR, 7th Sess., Supp. No. 20, at 24, U.N. Doc. A/2361 (1952); Uniform Computer Information Transactions Act, available at <http://www.law.upenn.edu/bll/ulc/fnact99/1990s/ucita.htm> (visited Mar. 28, 2000). See generally Int'l Chamber of Comm., Draft Uniform Rules of Conduct for Interchange of Trade Data by Teletransmission (UNCID), 3 COMPUTERL. \&PRAC. 105 (1987); ALAN SCHWARTZ \& SIMSON GARFINKEL, STOPPING SPAM (1998); Jonathan D. Aronson, Trade in Telecommunications Services, 19 GA. J. INT'L \& COMP L. 411 (1989); Jens Evensen, Aspects of International Law Relating to Modern Radio Communications, 115 RECUEIL DES COURS 471 (1965); Mark B. Feldman, Commercial Speech, Transborder Data Flows and the Right to Communicate under International Law, 17 INT'L LAW 87 (1983); A. Michael Froomkın, Flood Control on the Information Ocean: Living with Anonymity, Digital Cash, and Distributed Databases, 15 J. L. \& COM. 395 (1996); Robert M. Gellman, Can Privacy Be Regulated Effectively on a National Level? Thoughts on the Possible Need for International Prvacy Rules, 41 VILL. L. REV 129 (1996); David J. Goldstone, The Public Forum Doctrine in the Age of the Information Superhighway (Where Are the Public Forums on the Information Superhighway?), 46 HASTINGS L.J. 335 (1995); Martin E. Halstuk, Bits, Bytes, and the Right to Know: How the Electronic Freedom of Information Act Holds the Key to Public Access to a Wealth of Useful Government Databases, 15 SANTA CLARA COMPUTER \& HIGH TECH. L.J. 73 (1999); Christian A. Herter, Jr., The Electromagnetic Spectrum: A Critical Natural Resource, 25 NAT.RESOURCES J. 651 (1985); Howell, supra note 83; M. Ethan Katsh, Rights, Camera, Action: Cyberspatial Settings and the First Amendment, 104 YALE L.J. 1681 (1995) [hereinafter Katsh, Rights, Camera, Action]; Y.M. Kolossov, Prospects for the International Treaty on Telecommunications, 27 CAL. W L. REV 173 (1990); Karl P Sauvant, Transborder Data Flows and the Developing Countres, 37 INT'LORG. 359 (1983); David E. Sorkın, Unsolicited Commercial E-Mail and the Telephone Consumer Protection Act of 1991, 45 BUFF L. REV 1001 (1997); Symposium, Data Protection Law and the European Union's Directive: The Challenge for the United States, 80 IowAL.REV 431 (1995); R. Hayes Johnson, Jr., Case Note, Defamation in Cyberspace: A Court Takes a Wrong Turn on the Information Superhighway in Stratton Oakmont, Inc. v Prodigy Services, 49 ARK. L. REV 589 (1996); Dena R. Klopfenstein, Comment, Deciphering the Encryption Debate: A Constitutional Analysts of Current Regulations and a Prediction for the Future, 48 EMORY L.J. 765 (1999); Anthony Paul Miller, Teleinformatics, Transborder Data Flows and the Emerging Struggle for Information: An Introduction to the Arrval of the New Information Age, 20 ColuM. J.L. \& SoC. PROBS. 89 (1986); Ryan Alan Murr, Comment, Prvacy and Encryption in Cyberspace: First Amendment Challenges to ITAR, EAR and Thetr Successors, 34 SANDIEGO L. REV 1401 (1997); Matthew C. Siderits, Comment, Defamation in Cyberspace: Reconciling Cubby, Inc. v. 
used on the Internet has become a complex and troubling 1ssue. ${ }^{87}$ One of the more important such events, if only because states have hardly begun to address collective regulation, is the impending globalization of major financial markets, ${ }^{88}$ along with the emergence of international electronic commerce..$^{89}$

Compuserve, Inc. and Stratton Oakmont v. Prodigy Services Co., 79 MARQ. L. REV 1065 (1996); Solana, supra note 83; Speck, supra note 83; Varmer, supra note 83.

${ }^{87}$ See Dan L. Burk, Trademarks Along the Infobahn: A First Look at the Emerging Law of Cybermarks, 1 RICH. J.L. \& TECH. 1 (1995) <http://www.unch. edu/ solt/vlil/burk.html>;DanL. Burk, TrademarkDoctrnes for Global Electronic Commerce, 49 S. CAR. L. REV 695 (1998); Clark W. Lackert, International Efforts Against Trademark Counterfeiting, 1988 COLUM. BUS. L. REV 161, Jeffrey M. Samuels \& Linda B. Samuels, The Changing Landscape of International Trademark Law, 27 GEO. WASH. J. INT'L L. \& ECON. 433 (1993); Adnan Wolff, Comment, Pursuing Domain Name Pirates Into Uncharted Waters: Internet Domain Names That Conflict With Corporate Trademarks, 34 SAN DIEGO L. REV 1463 (1997); FTC StaffWants Net Registrars to Suspend Domains Having 'Clearly False' Contact Info, 68 U.S.L.W 2266 (Nov. 9, 1999); ICANN Accredits WIPO, supra note 6.

${ }^{88}$ See Thomas P VARTANIAN ET AL., 21st CENTURY MONEY, BANKING \& COMMERCE (1998); Charles W. Mooney, Jr., Beyond Negotiability: A New Model for Transfer and Pledge of Interest in Securities Controlled by Intermediarnes, 12 CARDOZO L. REV 305 (1990); David G. Oedel, Private Interbank Discipline, 16 HARV. J. L. \& PUB. POL'Y 327 (1993); Ruder, supra note 10; Sato, supra note 10; Lewis D. Solomon \& Louise Corso, The Impact of Technology on the Trading of Securities: The Emerging Global Market and the Implications for Regulation, 24 J.MARSHALLL.REV.299 (1991); Jane Kaufman Winn, Courzers Without Luggage: Negotiable Instruments and Digital Signatures, 49 S.C.L.REV 739 (1998); Bryan S. Schultz, Comment, Electronic Money, Internet Commerce, and the Right to Financial Privacy: A Call for New Federal Guldelines, 67 U. CIN. L. REV 779 (1999); Speer, supra note 6.

${ }^{89}$ See Draft Uniform Rules on Electronic Signatures, United Nations Commission on International Trade Law, 33d Sess., UN Doc. A/CN.9/WG.IV/WP.76 (May 25, 1998); Law on Electronic Transactions (Italy) (visited Mar. 30, 2000), <http://www.aipa.it/english[4/law[3/law5997.asp> (delegating Act, English translation); Presidential Decree No. 513 (visited Mar. 29, 2000) <http://www.aupa. it/english[4/law[3/pdecree51397.asp> (regulations, English translation); UNIF ELECTRONIC TRANSACTIONS ACT (1999) (visited Apr. 4, 2000), <http://www.law. upenn.edu/bll/ulc/fnact99/1990s/ueta99.pdf>; see generally EDWARDA.CAVAZOS \& GAVINO MORIN, CYBERSPACE AND THE LAW· YOUR RIGHTS AND DUTIES IN THE ON-IINE WORLD (1994); JOHN DICKIE, INTERNET AND ELECTRONIC COMMERCE 
LAW IN THE EUROPEAN UNION (1999); ALANM. GAHTAN ET AL., INTERNET LAW• A PRACTICAL GUIDE FOR LEGAL AND BUSINESS PROFESSIONALS (1998); DAVID JOHNSTON ET AL., CYBERLAW - WHAT YOU NEED TO KNOW ABOUT DOING BUSINESS ONLINE (2000); C. BradfordBiddle, Legislating Market Winners: Digital Signature Laws and the Electronic Commerce Marketplace, 34 SANDIEGOL. REV 1225 (1997); Leah Brannon, Regulating Drug Promotion on the Internet, 54 FOOD \& DRUG L.J. 599 (1999); Mark E. Budnitz, Prvacy Protection for Consumer Transactions in Electronic Commerce: Why Self-Regulation Is Inadequate, 49 S.C. L. REV 847 (1998); Walter A. Effross, The Legal Architecture of Virtual Stores: World Wide Web Sites and the Uniform Commercial Code, 34 SANDIEGO L. REV 1263 (1997); John P Freeman, A Business Lawyer Looks at the Internet, 49 S.C. L. REV 903 (1998); Jack L. Goldsmith, What Internet Gambling Legislation Teaches About Internet Regulation, 32 INT'LLAW 1115 (1998); John K. Halvey, The Virtual Marketplace, 45 EMORY L.J. 959 (1996); Larry Irving, Safeguarding Consumers' Interests in Cyberspace, 1996 U. CHI. LEGALF 1, Gregory E. Maggs, Internet Solutions to Consumer Protection Problems, 49 S.C. L. REV 887 (1998); Diana J.P McKenzie, Commercial Transactions on the Global Information Infrastructure: Commerce on the Net: Surfing Through Cyberspace Without Getting Wet, 14 J. MARSHALL J. COMPUTER \& INFO. L. 247 (1996); Thomas G. Melling, Washington's Electronic Authentication Act: Eliminating Legal Uncertainties Through Default Rules, 34 SAN DIEGO L. REV 1247 (1997); Christopher Millard \& Robert Carolina, Commerctal Transactions on the Global Information Infrastructure: A European Perspective, 14 J. MARSHALL J. COMPUTER \& INFO. L. 269 (1996); Morgan, supra note 6; Raymond T. Nimmer, Commercial Transactions on the Global Information Infrastructure: Electronic Contracting: Legal Issues, 14 J. MARSHALL J. COMPUTER \& INFO. L. 211 (1996); Paul, supra note 6; Henry H. Perritt, Jr. \& Margaret G. Stewart, False Alarm?, 51 FED. COMM. L.J. 811 (1999); R.J. Robertson, Jr., Electronic Commerce on the Internet and the Statute of Frauds, 49 S.C.L.REV 787 (1998); Howard B. Stravitz, Personal Jurndiction in Cyberspace: Something More is Required on the Electronic Stream of Commerce, 49 S.C.L.REV. 925 (1998); Symposium, Current Issues in Electronic Data Interchange: Defining International Electronic Commerce, supra note 10; Tebo, supra note 6; Catherine M. Downey, Comment, The High Price of a Cashless Society: Exchanging Privacy Rights for Digital Cash?, 14 J. MARSHALL J. COMPUTER \& INFO. L. 303 (1996); Christopher B. Woods, Comment, Commercial Law: Determining Repugnancy in an Electronic Age: Excluded Transactions Under Electrontc Writing and Signature Legislation, 52 OKLA. L. REV 411 (1999); Alvey \& Kaut, supra note 6; Bogino, Fraud Schemes, supra note 6; Coming Soon, supra note 6; Cutter, supra note 6; FDA Warns, supra note 6; Felsenthal, supra note 6; ICANN Accredits WIPO, supra note 6; McCarthy, supra note 6; McGolnck, supra note 6;OECD Gutdelines, supra note 6; Pyramid Schemes, supra note 6; U.S., EU Will Not Sign, supra note 6; U.S. Wary 
Resource management is in many respects the most pervasive area in which advancing technology creates new challenges for international law The development of the technology enabling the first meaningful exploration of Antarctica led immediately to a treaty regulating activities on the frozen continent, ${ }^{90}$ and the approach of technologies for exploiting Antarctica's natural resources has prompted a new treaty postponing, and perhaps preventing, the exploitation of those resources. ${ }^{91}$ Another early manifestation of the effects of new technologies for the exploitation of natural resources and the concentration of that technology in particular nations was the adoption by the United Nations General Assembly of the Resolution on Permanent Sovereignty over Natural Resources. ${ }^{22}$

The ongoing profound changes in the law of the sea provide particularly dramatic examples of such effects of science and technology Development of technology for the exploitation of offshore oil led directly to the emergence of an entirely new body of law relating to the continental shelf..$^{93}$ Modern fishing technology fostered the creation of a new concept

But Optimistic as EU States Craft Own E-Signature Laws Based on EC Directive, 68 U.S.L.W 2389 (Jan. 11, 2000).

${ }^{90}$ See Antarctic Treaty, supra note 74. See generally F.M.AUBURN, ANTARCTIC LAW ANDPOLITICS(1982); J. Peter A. Bernhardt, Sovereıgnty in Antarctica, 5 CAL. W INT'L L.J. 297 (1975).

${ }^{91}$ See Protocol on Environmental Protection to the Antarctic Treaty, Oct. 4, 1991, S. Treaty Doc. No. 102-22 (1992); Convention on the Regulation of Antarctic Mineral Resource Activities, Nov. 25, 1988, 27 I.L.M. 868; Convention on the Conservation of Antarctic Marine Living Resources, May 20, 1980, 33 U.S.T. 3476. See generally THE ANTARCTIC TREATY SYSTEM IN WORLD POLITICS (Arnfinn Jorgensen-Dahl \& Willy Ostreng eds., 1991); RUDIGER WOLFRUM, THE CONVENTION ON THE REGULATION OF ANTARCTIC MINERAL RESOURCE ACTIVITIES: AN ATTEMPT TO BREAKNEW GROUND (1.991); Symposıum, Antarctic Conservation, 4 GEO. INT'L ENVTL. L. REV 1 (1992).

${ }^{92}$ Resolution on Permanent Soveretgnty over Natural Resources, G.A. Res. 1803, U.N. GAOR, 17th Sess., Supp. No. 17, at 15 (1962), 2 I.L.M. 223 (1963). See generally Wang Xuan, Permanent Soveretgnty of States over Natural Resources, in SELECTED ARTICLES, supra note 31, at 125.

${ }^{93} \mathrm{See}$ North Sea Continental Shelf(F.R.G. v. Den., F.R.G. v. Neth.), 1969 I.C.J. 3 (Feb. 20); Convention on the Continental Shelf, Apr. 29, 1958, 15 U.S.T. 471, Arbitration between Petroleum Development (Trucial Coast) \& The Sheikh of Abu Dhab1, 1 INT'L \& COMP L.Q. 247 (1952); Proclamation No. 2667, 10 Fed. Reg. 12,303 (1945) (Proclamation of the Policy of the United States with Respect to the Natural Resources of the Subsoil and Sea Bed of the Continental Shelf) (the Truman Proclamation); see also BROWNLIE, supra note 28, at 214-32. See generally MYRES S.MCDOUGAL\& WILLIAM T.BURKE, THEPUBLIC ORDER OFTHE 
in the law of the sea known as the exclusive economic zone. ${ }^{94}$ The developing technology of exploiting mineral nodules and other resources prompted the articulation of the deep seabed as the "common heritage" of mankind $d^{95}$ and the still incomplete efforts to create an international management regime for that "common heritage of all mankind."96 While we have only recently, and tenuously, begun the effective international management of whales and related species,$^{97}$ the international community has begun to consider how effectively to coordinate the management of anadromous fish resources. ${ }^{98}$ These regimes, like the notion of straight baselines, owe as much to thenew technologies for the exercise of effective land-based authority over water areas, including for determining where a

OCEANS: A CONTEMPORARY INTERNATIONAL LAW OF THE SEA 630-729 (1962); 1 D.P O'CONNELL, THEINTERNATIONAL LAWOF THE SEA 467-509 (1.A. Shearer ed., 1982).

${ }^{94}$ See Fishenes Junsdiction (U.K. v. Ice.), 1974 I.C.J. 3 (July 25); DAvid ATTARD, THE EXCLUSIVE ECONOMIC ZONE IN INTERNATIONAL LAW (reprinted 1991); BROWNLIE, supra note 28, at 206-13, 224-25, 262-65; BARBARA KWIATKOWSKA, THE 200 MILE EXCLUSIVE ECONOMIC ZONE IN THE NEW LAW OF THE SEA (2000); SHIGERU ODA, INTERNATIONAL CONTROL OF SEA RESOURCES 4167 (rev. ed. 1989); Ann L. Hollick, The Ongins of 200-Mile Offshore Zones, 71 AM. J. INT'L L. 494 (1977); Shigeru Oda, Fisherres under the United Nations Convention on the Law of the Sea, 77 AM. J. INT'LL. 739 (1983); Peter H. Pearse, From Open Access to Private Property: Recent Innovations in Fishing Rights as Instruments of Fisheries Policy, 23 OCEAN DEV \& INT'LL. 71 (1992); Francisco Orrego Vicuña, La zone économıque exclustve: régime et nature jurdique dans le droit international, 199 RECUEIL DES COURS 9 (1986).

${ }^{95}$ See Declaration of Principles Governing the Sea-Bed and the Ocean Floor, and the Subsoil Thereof, beyond the Limits of National Jurndiction, Dec. 17, 1970, 10 I.L.M. 220.

${ }^{96}$ See United Nations Convention on the Law of the Sea, supra note 73; BROWNLIE, supra note 28, at 252-57; 1 O'CONNELL, supra note 93, at 449-57; Philippe Kirsch \& Douglas Fraser, The Law of the Sea Preparatory Commussion after Six Years: Review and Prospects, 26 CAN. Y.B.INT'LL. 119 (1988); Bernard H. Oxman, The High Seas and the International Seabed Area, $10 \mathrm{MrCH}$. J. INT'L L. 526 (1989).

${ }^{97}$ See International Convention for the Regulation of Whaling, Dec. 2, 1946, 62 Stat. 1716; MCDOUGAL \& BURKE, supra note 93, at 948-52; Patricia Birnie, The Role of Developing Countries in Nudging the International Whaling Commission from Regulating Whaling to Encouraging Nonconsumptive Uses of Whales, 12 ECOLOGY L.Q. 937 (1985); Anthony D'Amato \& SudhurK. Chopra, Whales: Their Emerging Right to Life, 85 AM. J. INT'L L. 21 (1991).

${ }^{98}$ See MCDOUGAL \& BURKE, supra note 93, at 952-55. 
vessel is located, as they do to the new technologies for exploiting resources located in the seas. ${ }^{99}$ This is exemplified by the broadening of the territorial sea from three to twelve miles. ${ }^{100}$ On the other hand, no comparable international regime has emerged for offshore deep water ports. ${ }^{101}$

The changing law of the sea is but one instance of the difficult problems involved in developing effective international regimes for the exploitation of shared or transboundary resources. ${ }^{102}$ For example, transboundary management of freshwater resources was histoncally limited to facilitating navigation. ${ }^{103}$ The development of technologies permitting the construction of major hydropower facilities and large-scale diversions

${ }^{99}$ See Fishernes Case (U.K. v. Nor.), 1951 I.C.J. 116 (Dec. 18); BROWNLIE, supra note 28 , at 181-87, 190-94; 3 J.H.W VERZIJ, INTERNATIONAL LAW IN HISTORICAL PERSPECTIVE 60-65 (1970); Lew1s M. Alexander, Baseline Delimitations and Maritime Boundartes, 23 VA.J. INT'LL. 503 (1983); Joseph W Dellapenna, The Philippınes Territornal Water Claim in International Law, 5 J.L. \& ECON. DEV 45 (1970).

${ }^{100}$ See BROWNLIE, supra note 28, at 187-89; MCDOUGAL \&BURKE, supra note 93, at 446-564.

${ }^{101}$ See H. Gary Knight, International Legal Aspects of Deep Draft Harbor Facilities, 4 J. MAR. L. \& COM. 367 (1973).

${ }^{102}$ See GLOBAL RESOURCES AND INTERNATIONAL CONFLICT: ENVIRONMENTAL FACTORS IN STRATEGIC POLICY AND ACTION (Arthur H. Westing ed., 1986); ROBERT MANDEL, CONFLICT OVER THE WORLD'S RESOURCES: BACKGROUND, TRENDS, CASE STUDIES, AND CONSIDERATIONS FOR THE FUTURE (1988); Rıchard B. Bilder, International Law and Natural Resources Policies, 20 NAT. RESOURCES J. 451 (1980); Stefano Burch,, Shared Natural Resources in the European Economıc Community Legislation, 25 NAT. RESOURCES J. 639 (1985); Ralph C. d'Arge \& Allen J. Kneese, State Liability for International Environmental Degradation: AnEconomic Perspective, 20 NAT.RESOURCES J.427 (1980); L.F.E. Goldie, Equity and the International Management of Transboundary Resources, 25 NAT. RESOURCES J. 665 (1985).

${ }^{103}$ See Convention and Statute on the Regime of Navigable Waterways of International Concern, Apr. 20, 1921, 7 L.N.TS 35 (entered into force Oct. 31, 1922); Venezuelan Preferential Case (Germany, Gr. Brit., Italy v Venez.) Hague Ct. Rep. (Scott) 55 (Perm. Ct. Arb. 1904); RICHARD R. BAXTER, THE LAW OF INTERNATIONAL WATERWAYS WITH PARTICULAR REGARD TO INTEROCEANIC CANALS (1964); BROWNLIE, supra note 28, at 273-74; GEORGES KAECKENBEECK, INTERNATIONAL RIVERS: A MONOGRAPH BASED ON DIPLOMATIC DOCUMENTS (1919); Ludwik A. Teclaff, Fiat or Custom: The Checkered Development of International Water Law, 31 NAT. RESOURCES J. 45, 46-59 (1991) [hereinafter Teclaff, Fiat or Custom]. 
of water for irngation and industral uses has created occasional international arbitrations over transboundary water resources, ${ }^{104}$ as well as bilateral or regional agreements on managing such resources. ${ }^{105}$ Together, these changes have created a body of customary unternational law which could be binding even on nations that have not formally accepted that law ${ }^{106}$ The General Assembly of the UN recently approved the Convention on the Law of Non-Navigational Uses of International Watercourses. ${ }^{107}$

${ }^{104}$ See Lake Lanoux (Fr. v. Spain) (Arb. Tribunal Nov 16, 1957), in 53 AM. J. INT'LL. 156 (1959); Case of the Territonal Junsdiction of the Int'l Comm'n of the Oder River, [1929] P.C.I.J., ser. A, No. 23 at 27

${ }^{105}$ See Act Regarding Navigation and Economic Co-operation between the States of the Niger Basin, Oct. 26, 1963, 587 U.N.T.S. 9 [hereinafter Niamey Treaty]; Indus Waters Treaty, Sept. 19, 1960, India-Pak., 419 U.N.T.S. 126, reproduced in 55 AM. J. INT'L L. 797 (1961); Treaty Relating to the Utilization of the Waters of the Colorado and Tijuana Rivers, and the Rio Grande, Feb. 3, 1944, U.S.-Mex., 59 Stat. 1219; General Convention Relating to the Development of Hydraulic Power Affecting More Than One State, Dec. 9, 1923, 36 L.N.T.S. 76; see also HERBERT A. SMITH, THE ECONOMIC USES OF INTERNATIONAL RIVERS, Appendix 1 (1931); Tiyanjana Maluwa, Legal Aspects of the Niger River under the Niamey Treaties, 28 NAT. RESOURCES J. 671 (1988); C.O. Okıdi, The State and the Management of International Drainage Basins in Afrnca, 28 NAT. RESOURCES J. 645 (1988); Symposium, U.S.-Canada Transboundary Resource Issues, 26 NAT. RESOURCES J. 201 (1986); Albert Utton, The Transfer of Water from an International Border Regzon: A Tale of Six Cities and the All Amencan Canal, 16 N.C. J. INT'L L. \& COM. REG. 477 (1991).

${ }^{106}$ See The Helsink Rules, in INTERNATIONAL LAW ASS'N, REPORT OF THE FIFTY-SECOND CONFERENCE, Helsink1, 1966, at 484 (1967) (rules on the uses of the waters of international rivers); BROWNLIE, supra note 28, at 271-76; LUIS VEIGA DA CUNHA ET AL., MANAGEMENT AND LAW FOR WATER RESOURCES 21124, 241-43 (1977); Teclaff, Fiat or Custom, supra note 103, at 59-73; Albert E. Utton, International Waters, in 5 WATERS AND WATER RIGHTS 3 (Robert E. Beck ed., 1991); see also Gretta Goldenman, Adapting to Climate Change: $A$ Study of International Rivers and Their Legal Arrangements, 17 ECOLOGYL.Q.741 (1990); Ernest T. Smerdon, Impact of Global Change on Water Resources, 9 ARIZ. J. INT'L \& COMP. L. 155 (1992); Ludwik A. Teclaff, The River Basin Concept and Global Climate Change, 8 PACE ENVTL. L. REV. 355 (1991) [hereinafter Teclaff, Global Climate Change]. But see F.J. BERBER, RIVERS IN INTERNATIONAL LAW 128-29 (1959). For similar problems and solutions regarding transboundary oil and natural gas deposits, see Alberto Szekély et al., Transboundary Hydrocarbon Resources: The Puerto Vallarta Draft Treaty, 31 NAT. RESOURCES J. 609 (1991).

${ }^{107}$ UN Convention on the Law of Non-Navigational Uses of International Watercourses, U.N. GAOR, 6th Comm., 2d Sess., U.N. Doc. No. A/51/869, arts. 2(c), (4) (1997); see also Malgosia Fitzmaurice, Convention on the Law of Non- 
Even with the customary law and a UN Convention, however, no truly contentious situation regarding internationally shared freshwaters can be resolved except through a complex negotiated agreement. ${ }^{108}$ In contrast with the considerable work done on surface water, the international community has barely begun to recognize the need to coordinate the management of transboundary aquifers. ${ }^{109}$

Moreover, the growing conflicts over the transfer of advanced technology to developing nations are related to the emergence of resource exploitation problems. ${ }^{110}$ As technological advances in some countries have widened the economic gap between those countries and less developed

Navigational Uses of International Watercourses, 10 LEIDEN J. INT'L L. 501 (1997); Stephen C. McCaffrey \& Mpazı Sinjela, The 1997 United Nations Convention on International Watercourses, 92 AM. J. INT'L L. 97 (1998); Attila Tanz1, The UN Convention on International Watercourses as a Framework for the Avordance and Settlement of Waterlaw Disputes, 11 LEIDEN J. INT'LL. 442 (1998).

${ }^{108}$ See Joseph W Dellapenna, Treaties as Instruments for Managing Internationally-Shared Water Resources: Restricted Sovereignty vs. Community of Property, 26 CASE W. RES. J. INT'LL. 27 (1994); Joseph W Dellapenna, Water in the Jordan Valley: The Potential and Limits of Law, 5 PALESTINE Y.B. INT'LL. 15 (1989) [hereinafter Dellapenna, Jordan Valley].

${ }^{109}$ See INTERNATIONAL LAW ASSOCIATION: REPORT OF THE SIXTY-SECOND CONFERENCE 21, 231-85 (1986); Ann Berkley Rodgers \& Albert E. Utton, The Ixtapa Draft Agreement Relating to the Use of Transboundary Groundwaters, in TRANSBOUNDARY RESOURCES LAW 151 (Albert E. Utton \& Ludwik A. Teclaff eds., 1987); LUDWIK A. TECLAFF \& ALBERT E. UTTON, INTERNATIONAL GROUNDWATER LAW (1981); Julio Barberis, The Development of International Law of Transboundary Groundwater, 31 NAT. RESOURCES J. 167 (1991); J. Roman Calleros, The Impact on Mexico of the Lining of the All-American Canal, 31 NAT. RESOURCES J. 829 (1991); Douglas Hayes, The All-Amercan Canal Lining Project: $A$ Catalyst for Rational and Comprehensive Groundwater Management on the United States-Mexico Border, 31 NAT. RESOURCES J. 803 (1991); Robert D. Hayton \& Albert E. Utton, Transboundary Groundwaters: The Bellagio Draft Treaty, 29 NAT. RESOURCES J. 663 (1989); see also Ray Jay Davis, Atmosphertc Water Resources Development and International Law, 31 NAT. RESOURCES J. 11 (1991).

${ }^{110}$ See KRISHNa R. DronamRaJu, Biological aND Social ISSUES IN BIOTECHNOLOGY SHARING (1998); Nicholas A. Ashford \& Christine Ayers, Policy Issues for Consideration in Transferring Technology to Developing Countrues, 12 ECOLOGY L.Q. 871 (1985); Pierre V.F Bos \& Marco M. Slotboom, The EC Technology Transfer Regulation-A Practitioner's Perspective, 32 INT'L LAW. 1 (1998); Stevan M. Pepa, Note, International Trade and Emerging Genetic Regulatory Regtmes, 29 LAW \& POL'Y IN INT'L BUS. 415 (1998). 
countries, the international community has introduced special provisions into the General Agreement on Tariffs and Trade to promote economic development. ${ }^{111}$ At the same time, it has been necessary, but far from easy, to develop international regulatory regimes for multinational corporations. ${ }^{112}$ The converse of this has been the need to perfect national and international protection for intellectual property ${ }^{113}$

111 See also Convention Establishing the Multilateral Investment Guaranty Agency, Oct. 11, 1985, 24 I.L.M. 1598; Charter of Economic Rights and Duties of States, G.A. Res. 3281, 29 U.N. GAOR, Supp. No. 31, at 50, U.N. Doc. A/9946 (1975); Declaration on the Establishment of a NewInternational Economic Order, G.A. Res. 3201, U.N. GAOR, 6th Sess., Supp. No. 1, at 3, U.N. Doc. A/9559 (1974); Protocol Amending the General Agreement on Tariffs and Trade to Introduce a Part IV on Trade and Development, Feb. 8, 1965, 17 U.S.T. 1977. See generally William E. Holder, International Economic Relations, 14 YALE J. INT'L L. 565 (1989); Yao Meızhen, Legal Protection of International Investment, in SELECTED ARTICLES, supra note 31, at 147

${ }^{112}$ See 1985 Report of Work on the Formulation of the United Nations Code of Conduct on Transnational Corporations, U.N. Centre on Transnat'l Corps., U.N. Doc. E/C.10/1985/S/2 (1985); OECD Declaration on International Investment and Multinational Enterprises, June 21, 1976, 15 I.L.M. 967

${ }^{113}$ See Berne Convention, supra note 76; Patent Cooperation Treaty, supra note 76; ANNE WELLS BRANSCOMB, WHO OWNS INFORMATION?: FROM PRIVACY TO PUBliC ACCESS (1994); PAUL GOLDSTEIN, COPYRIGHT'S HIGHWAY: FROM GUTENBERG TO THE CELESTIAL JUKEBOX (1994); INTELLECTUAL PROPERTY AND THE NATIONAL INFORMATION INFRASTRUCTURE: THE REPORT OF THE WORKING GROUP ON INTELLECTUAL PROPERTY RIGHTS (1995); Keith Aokı, Considering Multiple and Overlapping Sovereignties: Liberalism, Libertarianism, National Sovereignty, "Global" Intellectual Property, and the Internet, 5 IND. J. GLOBAL LEGAL STUD. 443 (1998); Keith Aok, (Intellectual) Property and Sovereignty: Notes Toward a Cultural Geography of Authorshlp, 48 STAN.L.REV 1293 (1996); Harold J. Bordwin, The Legal and Political Implications of the International Undertakng on Plant Genetic Resources, 12 ECOLOGY L.Q. 1053 (1985); Michael Bothe, Transborder Data Flows: Do We Mean Freedom or Business?, $10 \mathrm{MICH}$. J. INT'L L. 333 (1989); Jack E. Brown, The Protection of High Technology Intellectual Property: An International Perspective, 7 COMPUTER LAW. 17 (1990); Dan L. Burk, Muddy Rules for Cyberspace, 21 CARDOZo L. REV 121 (1999); Dan L. Burk, Patents in Cyberspace: Territoriality and Infringement on Global Computer Networks, 68 TUL.L. REV 1 (1993); Steve P Calandrillo, An Economic Analysis of Property Rights in Information: Justifications and Problems of Exclustve Rights, Incentives to Generate Information, and the Alternative of a Government-Run Reward System, 9 FORDHAM INTELL. PROP. MEDIA \& ENT. L.J. 301 (1998); Frank Emmert, Intellectual Property in the Uruguay Round-Negotiating Strategzes of the Western Industralized Countries, $11 \mathrm{MrCH}$. 
J. INT'L L. 1317 (1990); Jay A. Erstling, The Semiconductor Chip Protection Act and Its Impact on the International Protection of Chip Designs, 15 RUTGERS COMPUTER \& TECH. L.J. 303 (1989); Jane C. Ginsburg, Global Use/Territorial Rights: Prvate International Law Questions of the Global Information Infrastructure, 42 J. COPYRIGHT SOC'Y U.S.A. 318 (1995); I. Trotter Hardy, Computer RAM "Coptes" Hit or a Myth? Historical Perspectives on Caching as a Microcosm of Current Copynght Concerns, 22 U. DAYTON L. REV 423 (1997); Dennıs S. Karjala, United States Adherence to the Berne Convention and Copyright Protection of Information-Based Technologies, 28 JURIMETRICS 147 (1988); William J. Keating, The European Community-1992 and Beyond: The Implications of a Single Europe on Intellectual Property, 9 DICK. J. INT'L L. 53 (1991); Clark W.Lackert, International Efforts Against Trademark Counterfeiting, 1988 COLUM. BUS. L. REV 161, Marshall A. Leaffer, Protecting United States Intellectual Property Abroad: Toward a New Multilateralism, 76 IOWAL.REV. 273 (1991); Mark A. Lemley, Dealing with Overlapping Copyrights on the Internet, 22 U. DAYTON L. REV 547 (1997); André Lucas, Copynght in the European Community: The Green Paper and the Proposal for a Directive Concerning Legal Protection of Computer Programs, 29 COLUM. J. TRANSNAT'L L. 145 (1991); Charles R. McManis, Taking TRIPS on the Information Superhighway: Intemational Intellectual Property Protection and Emerging Computer Technology, 41 VILL. L. REV 207 (1996); Michael S. Mensik, Software Localization: Hidden Issues that Aruse when Software Is Translated Abroad, 8 COMPUTER LAW. 1 (1991); Andreas P Reindl, Choosing Law in Cyberspace: Copyright Conflicts on Global Networks, 19 MiCH. J. INT'L L. 799 (1998); Pamela Samuelson, The U.S. Digital Agenda at WIPO, 37 VA. J. INT'L L. 369 (1997); Raimund Steiner \& Robert P Sabath, Intellectual Property and Trade Law Approaches to Gray Market Importation, and the Restructurng of Transnational Entities to Permit Blockage of Gray Goods in the United States, 15 WM. MITCHELL L. REV 433 (1989); Symposium, The Berne Convention, 3 J.L. \& TECH. 1 (1988); Symposium, Trade-Related Aspects of Intellectual Property, 22 VAND. J. TRANSNAT'L L. 223 (1989); Deborah Tussey, Owning the Law: Intellectual Property Rights in Primary Law, 9 FORDHAM INTELL. PROP MEDIA \& ENT. L.J. 173 (1998); Victor Vandebeek, Realizing the European Community Common Market by Unifying Intellectual Property Law: Deadline 1992, 1990 BYU L. REV 1605; James R. Warnot, Jr., Software Copynght Protection in the European Community: Existing Law and an Analysis of the Proposed Council Directive, 6 SANTA ClaRA COMPUTERS \& HIGH TECH. L.J. 355 (1991); Jo Dale Carothers, Note, Protection of Intellectual Property on the World Wide Web: Is the Digital Millennum Copynght Act Sufficient?, 41 ARIZ. L. REV 937 (1999); Benjamin R. Kuhn, Comment, A Dilemma in Cyberspace and Beyond: Copyright Law for Intellectual Property Distributed over the Information Superhighway of Today and Tomorrow, 10 TEMPLE INT'L \& COMP. L.J. 171 (1996); Matthew J. McDonough, Note, Moral Rights and Movtes: The Threat and Challenge of the Digital Domain, 
As the prior summary of problems relating to resource management suggests, almost any problem of envronmental management today has an international dimension. ${ }^{114}$ The international community has recently recognized that international dimension of even such apparently localized activities as the preservation of biodiversity ${ }^{115}$ The all-encompassing

31 SuFF U. L. REV 455 (1997); Brandon K. Mura1, Comment, Online Service Providers and the Digital Millennium Copyright Act: Are Copyright Owners Adequately Protected, 40 SANTA CLARA L. REV 285 (1999).

${ }^{114}$ See HaRALD HOHMANN, PRECAUTIONARY LEGAL DUTIES AND PRINCIPLES OF MODERN INTERNATIONAL ENVIRONMENTAL LAW (1994); Sanford E. Gaines, Taking Responsibility for Transboundary Environmental Effects, 14 HASTINGS INT'L \& COMP. L. REV 781 (1991); Lawrence A. Herzog, International Boundary Cities: The Debate on Transfrontier Planning in Two Border Regions, 31 NAT. RESOURCES J. 587 (1991); Alexander Kiss, The Protection of the Rhine against Pollution, 25 NAT. RESOURCES J. 613 (1985); Harold Craig Manson, The Impact of International Outer Space Commerce on the Environment, 26 TEX. INT'L L.J. 541 (1991); Nancy Maynard, Sclence: The Basts for Action on Global Change, 9 ARIZ. J. INT'L \& COMP. L. 35 (1992); Thayer Scudder, The Need and Justification for Maintaining Transboundary Flood Regimes: The Africa Case, 31 NAT. RESOURCES J. 75 (1991); Linda M. Sheehan, The EEC's Proposed Directive on Civil Liability for Damage Caused by Waste: Taking over When Prevention Fails, 18 ECOLOGY L.Q. 405 (1991); Symposium, The Politics of the Global Environment, 44 J. INT'L AFF 287 (1991); Ludwik A. Teclaff, Treaty Practice Relating to Transboundary Flooding, 31 NAT. RESOURCES J. 109 (1991); Ludwik A. Teclaff \& Eileen Teclaff, Transboundary Toxtc Pollution and the Drainage Basin Concept, 25 NAT. REsourCES J. 589 (1985); Patrick E. Thieffry \& Peter E. Nahmias, The European Community's Regulation and Control of Waste and the Adoption of Civil Liability, 14 HASTINGS INT'L \& COMP L. REV 949 (1991); Alexandre S. Timoshenko, The Problem of Preventing Damage to the Envtronment in National and International Law: Impact Assessment and International Consultations, 5 PACE ENVTL. L. REV 475 (1988); Alexandre S. Timoshenko, Protection of Wetlands by International Law, 5 PACE ENVTL. L. REV 463 (1988); Kathleen Howard, Note, The Basel Convention: Control of Transboundary Movement of Hazardous Wastes and Their Disposal, 14 HASTINGS INT'L \& COMP L. REV 223 (1991).

${ }^{115}$ See Convention on Biological Diversity, June 5, 1992, reprinted in 31 I.L.M.

818; JEFFREY A. MCNEELY ET AL., CONSERVING THE WORLD's BIOLOGICAL DIVERSITY (1990); David J. Bederman, International Control of Marine "Pollution" by Exotic Species, 18 ECOLOGY L.Q. 677 (1991); M.J. Bowman, The Protection of Antmals Under International Law, 4 CONN. J. INT'L L. 487 (1989); Gary D. Meyers, Surveying the Lay of the Land, Air, and Water. Features of Current International Environmental and Natural Resources Law, and Future Prospects for the Protection of Species Habitat to Preserve Global Biological 
problem of global warming is the most pervasive problem and is irrefutable proof of the inherently international nature of such issues. Global warming will affect the well-being of the entire planet, altering the climate with unpredictable and potentially catastrophic consequences, ${ }^{116}$ as well as raising sea levels and distorting nipanan patterns with disastrous results for both rural and urban dwellers. ${ }^{117}$ Because of the potentially senous consequences, the threat of global warming has led nations to adopt measures to regulate or suppress some of the most salient causes of global warming, particularly chlorofluorocarbons. ${ }^{118}$

Diversity, 3 COLO. J. INT'L ENVTL. L. \& POL'Y 479 (1992); William M. Flevares, Note, Ecosystems, Economics, and Ethics: Protecting Biological Diversityat Home and Abroad, 65 S. CAL. L. REV 2039 (1992).

${ }^{116}$ See INTERNATIONAL LAW AND GLOBAL ClIMATE CHANGE (Robin Churchill \& David Freestone eds., 1991); Joseph W. Dellapenna, Adapting the Law of Water Management to Global Climate Change and Other Hydropolitical Stresses, $35 \mathrm{~J}$. AM. WATER RESOURCES ASS'N 1301 (1999); Goldenman, supra note 106; Lakshman Guruswamy, Global Warming: Integrating United States and International Law, 32 ARIZ. L. REV 221 (1990); Smerdon, supra note 106; Chnstopher D. Stone, Beyond Rio: "Insurng" against Global Warming, 86 AM. J.INT'L L. 445 (1992); Symposium, Energy and Environment: Intersecting Global Issues, 9 ARIZ. J. INT'L \& COMP L. 1 (1992); Symposium, Global Climatic Change, 10 DEN.J.INT'LL.\&POL'Y 463 (1981); Teclaff, Global Climate Change, supra note 106.

${ }^{117}$ See David D. Caron, When Law Makes Climate Change Worse: Rethınkng the Law of Baselines in Light of a Rising Sea Level, 17 ECOLOGY L.Q. 621 (1990); Samuel Pyeatt Menefee, "Half Seas Over" The Impact of Sea Level Rise on International Law and Policy, 9 UCLA J. ENVTL. L. \& POL'Y 175 (1991); Joseph L. Sax, The Fate of Wetlands in the Face of Rising Sea Levels: A Strategic Proposal, 9 UCLA J. ENVTL. L. \& POL'Y 143 (1991).

${ }^{118}$ See United Nations Conference on Environmental and Development: Framework Convention on Climate Change, Intergovernment Negotiating Comm., 5th Sess., pt. 2 (1992), 31 I.L.M. 849; Montreal Protocol on Substances that Deplete the Ozone, Sept. 16, 1987, 26 I.L.M. 1541, Vienna Convention for the Protection of the Ozone Layer, Mar. 22, 1985, S. TREATY Doc. No. 99-9 (1985); see also David D. Caron, Protection of the Stratosphenc Ozone Layer and the Structure of International Environmental Lawmaking, 14 HASTINGSINT'L \& COMP.L.REV 755 (1991); Susan E. Holley, Global Warming: Construction and Enforcement of an International Accord, 10 STAN. ENVTL. L.J. 44 (1991); Joel A. Mintz, Keeping Pandora's Box Shut: A Critical Assessment of the Montreal Protocol on Substances that Deplete the Ozone Layer, 20 U. MIAMI INTER-AM. L. REV 565 (1989); Ved P Nanda, Stratospheric Ozone Depletion: A Challenge for International Environmental Law and Policy, 10 MICH. J. INT'L L. 482 (1989); Steven J. 
For few other areas of environmental management, however, has international response progressed beyond high-sounding declarations ${ }^{119}$ to practical and enforceable measures of international cooperation. ${ }^{120} \mathrm{All}$ too

Shimberg, Stratospheric Ozone and Climate Protection: Domestic Legislation and the International Process, 21 ENVTL. L. 2175 (1991); Pamela Wexler, Protecting the Global Atmosphere: Beyond the Montreal Protocol, 14 MD. J. INT'L L. \& TRADE 1 (1990); Jason M. Patlis, Note, The Multilateral Fund of the Montreal Protocol: A Prototype for Financial Mechanisms in Protecting the Global Environment, 25 CORNELL INT'L L.J. 181 (1992).

${ }^{119}$ See Report of the United Nations Conference on the Human Environment, U.N. Doc. A/Conf.48/14 (1972), reprinted in 11 I.L.M. 1416; see also VEIR KOESTER, THE RAMSAR CONVENTION ON THE CONSERVATION OF WETLANDS: A LEGAL ANALYSIS OF THE ADOPTION AND IMPLEMENTATION OF THE CONVENTION IN DENMARK (1989); INTERNATIONAL ENVIRONMENTAL LAW- PRIMARY MATERIALS 1-111 (Michael R. Molitor ed., 1991) [hereinafter PRIMARY MATERIALS]; Dominique Alheritiere, Settlement of Public International Disputes on Shared Resources: Elements of a Comparative Study of International Instruments, 25 NAT. RESOURCES J. 701 (1985); Caldwell, supra note 15; James Cameron \& Juli Abouchar, The Precautionary Princtple: A Fundamental Prnnciple of Law and Policy for the Protection of the Global Environment, 14 B.C. INT'L \& COMP.L.REV 1 (1991); David D. Caron, The Law of the Environment: A Symbolic Step of Modest Value, 14 YALE J. INT'L L. 528 (1989); Pierre-Mare Dupuy, Soft Law and the International Law of the Environment, 12 MiCH. J. INT'L L. 420 (1991); Richard A. Falk, Toward a World Order Respectful of the Global Ecosystem, 19 B.C.ENVTL.AFF.L.REV 711 (1992); Mark Allan Gray, The United Nations Environment Programme: An Assessment, 20 ENVTL. L. 291 (1990); Ellen Hey, The Precautionary Concept in Environmental Policy and Law: Institutionalizing Caution, 4 GEORGETOWN INT'L ENVTL. L. REV 303 (1992); David B. Hunter, Toward Global Citizenship in International Environmental Law, 28 WILlameTtE L. REV 547 (1992); Alexandre S. Timoshenko, International Environmental Law: Fundamental Aspects, 59 REVISTA JURIDICA U.P.R. 653 (1990).

${ }^{120}$ See PRIMARYMATERIALS, supra note 119, at 113-571; STANLEY P.JOHNSON \& GUY CORCELLE, THE ENVIRONMENTAL POLICY OFTHEEUROPEANCOMMUNITIES (1989); Sanford E. Gaines, The Polluter-Pays Principle: From Economic Equity to Environmental Ethos, 26 TEX. INT'L L.J. 463 (1991); R.J.A. Goodland, The World Bank's Environmental Assessment Policy, 14 HASTINGS INT'L \& COMP L. REV 811 (1991); Ursula Kettlewell, The Answer to Global Pollution? A Critical Examination of the Problems and Potential of the Polluter-Pays Princzple, 3 CoLo. J. INT'L ENVTL. L. \& POL'Y 429 (1992); A.V. Leont'eva, Cooperation of Socialist Countries in Environmental Protection, 4 CONN. J. INT'L L. 479 (1989); Franço1s A. Mathys, International Environmental Law: A Canadian Perspective, 3 PACE Y.B. INT'L L. 91 (1991); Bernard H. Oxman, The Duty to Respect Generally 
often, the available "hard law" 1s not enforced or effective even when it exists. ${ }^{121}$

One can look to the Mediterranean, a shallow enclosed sea particularly vulnerable to environmental abuse, as a particularly clear example of the mounting international problems. In this century, the Mediterranean has been despoiled by nearly every coastal state and, despite high-sounding agreements to protect the sea, continues to deteriorate with little being done to correct the situation. ${ }^{122}$ Even less has been done regarding pollution of less vulnerable seas. ${ }^{123}$

The same high-sounding declarations coupled with largely inadequate implementation also pertain to the emerging international law of human

Accepted International Standards, 24 N.Y.U. J. INT'L L. \& POL. 109 (1991); Amedeo Postiglione, A More Efficient International Law on the Environment and Setting Up an International Court for the Environment within the United Nations, 20 ENVTL. L. 321 (1990); Report of the Working Group of Experts from the Member States on the Use of Economic and Fiscal Instruments in EC Environmental Policy, 14 B.C. INT'L \& COMP. L. REV 447 (1991); Peter M. Sand, Lessons Learned in Global Environmental Governance, 18 B.C. ENVTL. AFF L. REV 213 (1991); Ibrahım F.I. Shihata, The World Bank and the Environment: $A$ Legal Perspective, 16 MD. J. INT'L L. \& TRADE 1 (1992); Stone, supra note 116; Jeff Trask, Note, Montreal Protocol Noncompliance Procedure: The Best Approach to Resolving International Environmental Disputes?, 80 GEO. L.J. 1973 (1992).

${ }^{121}$ See Thomas K. Plofchan, Jr., Recognizing and Countervailing Environmental Subsidies, 26 INT'L LAW 763 (1992) (arguing that a nation that fails to compel its industries to internalize the costs of their pollution is thereby subsidizing the offending industry which should make the industry subject to countervailing duties under the General Agreement on Tariffs and Trade and U.S. law).

${ }^{122}$ See PETER HAAS, SAVING THE MEDITERRANEAN: THE POLITICS OF INTERNATIONAL ENVIRONMENTAL CoOperation (1990); Aldo E. Chircop, The Mediterranean Sea and the Quest for Sustainable Development, 23 OCEAN DEV \& INT'L L. 17 (1992).

${ }^{123}$ See Matthew R. Auer, Prospects for Environmental Cooperation in the Yellow Sea, 5 EMORY INT'L L. REV 163 (1991); Alan E. Boyle, Marne Pollution under the Law of the Sea Convention, 79 AM. J. INT'L L. 347 (1985); William L. Schachte, Jr., The Value of the 1982 UN Convention on the Law of the Sea: Preserving our Freedoms and Protecting the Environment, 23 OCEAN DEV \& INT'LL. 55 (1992); LudwikA. Teclaff \& Eileen Teclaff, Transfers of Pollution and the Marne Environment Conventions, 31 NAT. RESOURCES J. 187 (1991); Yvonne Tharpes, International Envtronmental Law: Turning the Tide on Marme Pollution, 20 U. MIAMI INTER-AM. L. REV 579 (1989). 
rights. ${ }^{124}$ In fact, one certain indication that the appeal for international action to protect the environment involves little more than dramatic declarations is the couching of it in terms of a supposed "human right to an appropriate environment."125 Both protecting the environment and promoting respect for human nights have, thus far, simply foundered on the continuing failure of the proponents of those norms to resolve the related problems of respecting cultural diversity and promoting a more uniform economic development among the nations of the world, as much as on selfish nationalism. ${ }^{126}$

${ }^{124}$ See International Covenant on Civil and Political Rughts, Dec. 16, 1966, 6 I.L.M. 368 (entered into force Mar. 23, 1976); International Covenant on Economic, Social, and Cultural Rights, Dec. 16, 1966, 6 I.L.M. 360 (entered into force Jan. 3, 1976); Convention on the Prevention of Genocide, Dec. 9, 1948, 78 U.N.T.S. 277; Unıversal Declaration of Human Rights, G.A. Res. 217 (1948), reprinted in INTERNATIONAL HUMAN RIGHTS OF THE UNITED STATES, at 5 (1983); see also BROWNLIE, supra note 28, at 553-602; JACK DONNELLY, UNIVERSAL HUMAN RIGHTS IN THEORY AND PRACTICE (1989); JANIS, supra note 28, at 249-80; HERSCH LAUTERPACHT, INTERNATIONALLAW ANDHUMANRIGHTS (1950); MYRES S. MCDOUGAL ET AL., HUMAN RIGHTS AND WORLD PUBLIC ORDER: THE BASIC POLICIES OF ANINTERNATIONAL LAW OF HUMANDIGNITY (1980);FRANK NEWMAN \& DAVID WEISSBRODT, INTERNATIONAL HUMAN RIGHTS: LAW, POLICY, AND PROCESS (1990); Lea Brilmayer, International Remedies, 14 YALE J. INT'LL. 579 (1989); A. Belden Fields \& Wolf-Dieter Narr, Human Rights as a Holistic Concept, 14 HUM. RTs. Q. 1 (1992); Lous Henkın, International Human Rights as "Rights," 1 CARDOZOL.REV 425 (1980); Douglas Sanders, Collective Rights, 13 HUM.RTs. Q. 368 (1991); Theo Van Boven, The Role of the United Nations Secretariat in the Area of Human Rights, 24 N.Y.U. J. INT'L L. \& POL. 69 (1991).

${ }^{125}$ Iveta Hodkova, Is There a Right to a Healthy Environment in the International Legal Order?, 7 CONN.J.INT'LL. 65, 123 (1991); see also Dinah Shelton, Human Rights, Environmental Rights, and the Right to Environment, 28 STAN. J. INT'L L. 103 (1991); Janusz Symonides, The Human Right to a Clean, Balanced and Protected Environment, 20 INT'L J. LEGAL INFO. 24, 34 (1992); Vid Vukasovic, Protection of Environment: One of the Key Issues in the Field of Human Rights, 59 REVISTA JURIDICA U.P.R. 889 (1990).

${ }^{126} \mathrm{~S} e e$ J. RONALD ENGEL \& JOAN GIBB ENGEL, ETHICS OF ENVIRONMENT AND DEVELOPMENT: GLOBAL CHALLENGE, INTERNATIONALRESPONSE(1990); MiCHAEL RADCLIFF, SUSTAINABLE DEVELOPMENT: EXPLORING THE CONTRADICTIONS (1991); Derek Asiedu-Akrofi, Debt-for-Nature Swaps: Extending the Frontiers of Innovative Financing in Support of the Global Environment, 25 INT'L LAW 557 (1991); Beijing Declaration on Environment, Development, BEIJING REV., July 8, 1991, at 10; Chen, supra note 29; Douglas Lee Donoho, Relativism Versus Universalism in Human Rights: The Search for Meaningful Standards, 27 STAN. 
Finally, one can never overlook the impact of the changes in our ability to exert control over procreation, disease, and death. ${ }^{127}$ While such developments have been dealt with mostly on the national level, it has already been noted that such activities, if they are to be regulated at all, must be regulated internationally ${ }^{128}$ If even one nation breaks ranks with a generally accepted approach to regulating bromedical research and application, then those who wish to pursue such research or applications will gravitate to that nation. We will see a sort of "Gresham's law" in which "bad" regulatory regimes will drive out "good" regulatory regimes. ${ }^{129}$

J. INT'L L. 345 (1991); Jennifer Drogula, Developed and Developing Countres: Sharng the Burden of Protecting the Atmosphere, 4 GEO. INT'L ENVTL. L. REV 257 (1992); Karen A. Goldberg, Efforts to Prevent Misuse of Pesticıdes Exported to Developing Countries: Progressing Beyond Regulation and Notification, 12 ECOLOGY L.Q. 1025 (1985); Raymond Hill, Problems and Policy for Pestictde Exports to Less Developed Countries, 28 NAT. RESOURCES J. 699 (1988); John Horberry, The Accountability of Development Assistance Agencies: The Case of Environmental Policy, 12 ECOLOGY L.Q. 817 (1985); Robert Houseman, The Muted Voice: The Role of Women in Sustainable Development, 4 GEO. INT'L ENVTL. L. REV 361 (1992); Ronne D. Lipshutz, Wasn't the Future Wonderful? Resources, Environment, and the Emerging Myth of Global Sustainable Development, 2 COLO. J. INT'L ENVTL. L. \& POL'Y 35 (1991); Daniel Barstow Magraw, Legal Treatment of Developing Countrnes: Differential, Contextual, and Absolute Norms, 1 COLO. J. INT'L ENVTL. L. \& POL'Y 69 (1990); Ved P Nanda, International Environmental Protection and Developing Countrzes' Interests: The Role of International Law, 26 TEX.INT'LL.J.497 (1991); John O'Manqque, Human Rights and Development, 14 HUM. RTS. Q. 78 (1992); Bruce M. Ruch, The Multilateral Development Banks, Environmental Policy, and the United States, 12 ECOLOGY L.Q. 681 (1985); Roland Y. Rich, The Right to Development as an Emerging Human Right, 23 VA. J. INT'L L. 287 (1983); Robert Saunders, Is It Economically Viable for Developing Countries to Cut Down Carbon Dioxtde Emissions?, 9 ARIZ. J. INT'L \& COMP L. 205 (1992); William Wilson, Environmental Law as Development Assistance, 22 ENVTL. L. 953 (1992); Harold Wood, Jr., The United Nations World Charterfor Nature: The Developing Nations' Initiative to Establish Protections for the Environment, 12 ECOLOGY L.Q. 977 (1985).

${ }^{127}$ See supra notes 7-9 and accompanying text.

${ }^{128}$ See, e.g., Melissa Cantrell, International Response to Dolly: Will Scientific Freedom Get Sheared?, 13 J. L. \& HEALTH 68 (1998).

129 "Gresham's law," formulated by Thomas Gresham in the sixteenth century, holds that if more than one specie of currency is circulating in a society, people will hoard the more valuable specie and spend the less valuable specie; in short, "bad money" will drive out "good money." JOHN KENNETH GALBRAITH, MONEY. 


\section{B. Means Alteration}

As the foregoing summary suggests, the influence of science and technology on the ends pursued by international law has been pervasive, posing new problems or exacerbating old problems that transcend national boundaries. In principle, science and technology should provide the means for solving problems confronting international lawyers. This sometimes happens by making steps practical that were previously impractical. I have already described how the dramatic changes in the law of the sea reflected as much the new technologies enabling effective surveillance and enforcement of enlarged coastal state authority as they did new interests in coastal margins - if two hundred or more miles from the coast can be considered a margin. ${ }^{130}$ Broad assertions of coastal-state authority over large expanses of water have occurred for centures, ${ }^{131}$ but without any means for making such claims effective. ${ }^{132}$ Only within the past twenty-five years have the necessary means existed. ${ }^{133}$

Another long-standing problem has been the possibility of a representative of a nation exceeding the authority delegated to that representative. ${ }^{134}$ While technology has not entirely eliminated this problem, the abilities of the sending state to keep abreast of negotiations and of the receiving state to verify the diplomat or other agent's authority should a question regarding that authority arise have greatly ameliorated the problem. These changes are entirely a function of modern communications technology A similar transformation might be impending regarding patents and copynghts as we develop the technology to store data holograph1cally-including models of what is protected by the legal nght. ${ }^{135}$

WHENCE IT CAME, WHERE IT WENT 10 (1975). By extension, it stands for the proposition that an inferior product, in a particular setting, will displace a superior product. See D.A.F., Gresham's Law of Legal Commentary, 3 CONST. COMMENTARY 307 (1986).

${ }^{130}$ See supra notes 93-101 and accompanying text.

${ }^{131}$ See JOHN SELDEN, OF THE DOMINION: OR OWNERSHIP OF THE SEA (reprint ed. 1979) (1635); WILLIAM WELWOOD, AN ABRIDGEMENT OF ALL SEA-LAWES (1613).

${ }^{132}$ See HUGO DE GROOT (GROTIUS), MARE LIBERUM (1633); see also CORNELIUS VAN BYNKERSHOEK, DE DOMINIO MARIS DISSERTATIO (reprint ed. 1923) (1702). See generally Daniel Wilkes, The Use of World Resources Without Conflict: Myths about the Territorial Sea, 14 WAYNE L. REV 441 (1968).

${ }^{133}$ See supra notes 99-100 and accompanying text.

${ }^{134}$ See Legal Status of Eastern Greenland (Den. v. Nor.), 1933 P.C.I.J. (ser. A/B) No. 53 (Apr. 5).

${ }^{135}$ See Patti Burshtyn, Note, Illuminating the Law of Copyright: Holographic Data Storage Takes Intellectual Property to a New Dimension, 9 FORDHAM 
Unfortunately, alterations of the means whereby international law functions are far less pervasive than the creation of new problems or the exacerbation of old ones. Often, the only solution is to ban the technology in question, ${ }^{136}$ yet prohibition of a product or process must await the development of effective means to detect violations of the prohibition. Again, nuclear devices provide the most dramatic examples. It is no accident that three nuclear powers agreed nearly thirty years ago not to conduct nuclear tests in the atmosphere, ${ }^{137}$ where the tests are easily detectable, while neither they nor other interested nations have effectively banned underground nuclear tests. Similarly, the United States and the Soviet Union agreed early on to limit the development and deployment of anti-ballistic missile systems because such systems could not be tested without detection. ${ }^{138}$ Agreements to control the proliferation of nuclear weapons are still bedeviled by the inability to detect violations. ${ }^{139}$ Indeed, Soviet-Amencan agreements to reduce nuclear arsenals only became possible when satellite and other surveillance techniques made the risk of cheating small enough to justify the agreement. . $^{140}$

Enforceability also presents a senous challenge to the effectiveness of many environmental management treaties. Consider, for example, how one will trace violations of the ban on chlorofluorocarbons by the Montreal

INTELL.PROP.MEDIA\&ENT.L.J.361 (1998); MarkHalper, Putting Mount Everest into an Anthill, FORBES, July 7, 1997, at 208.

${ }^{136}$ See supra note 118 (sources discussing the banning of chlorofluorocarbon technologies).

${ }^{137}$ See supra note 78.

${ }^{138}$ See ABM Treaty, supra note 79. Subsequent technical developments have unstabilized this treaty as the United States has changed its interpretation of the meaning of the test-ban aspects of the treaty while the Soviet Union insisted on the earlier interpretation. See also FRANCIS ANTHONY BOYLE, THE FUTURE OF INTERNATIONAL LAW AND AMERICAN FOREIGN POLICY 383-91 (1989); David Koplow, Constitutional Bait and Switch: Executive Reinterpretation of Arms Control Treaties, 137 U. PA. L. REV 1353 (1989); Detlev F Vagts, Senate Maternals and Treaty Interpretation: Some Research Hints for the Supreme Court, 83 AM. J. INT'L L. 546 (1989).

${ }^{139}$ See supra note 79.

${ }^{140}$ See Agreement on Prnciples of Implementing Tral Verification and Stab1lity Measures That Would Be Carned Out Pending the Conclusion of the U.S.Soviet Treaty on the Reduction and Limitation of Strategic Offensive Arms, United States-USSR, Sept. 23, 1989, 28 I.L.M. 1434; Treaty on the Elimination of Intermediate-Range and Shorter-Range Missiles, United States-USSR, Dec. 8, 1987, 27 I.L.M. 90. 
Protocol. ${ }^{141}$ The problem of detection is so pervasive in the environmental field that entire books have been written on the problem. ${ }^{142}$

The nuclear weapons examples illustrate a different problem in relying on technology to solve international (or other) legal problems. Solutions depend not only on the existence of approprate technology, but also on the political willingness of the necessary actors to employ that technology effectively Thus, the nuclear proliferation and disarmament treaties have never included certain major nuclear powers who, for reasons sufficient to themselves, have never joined (or have never been asked to join) the treaty even though the surveillance technology would be equally effective applied to, or by, the absent states. Similarly, treaties addressing the highjacking or sabotage of civilian aurcraft have always suffered from the refusal of certain key states to adhere to the agreements. ${ }^{143}$

Arguably, the most far-reaching consequence of many modern technologies working in tandem has been the obsolescence of national sovereignty, at least for states with less than several hundred million people. ${ }^{144}$ Even in such relatively localized questions as steps to protect children from exposure to pornography or molestation, we find that the problem is global and cannot be dealt with adequately at the national or local level. ${ }^{145}$ In fact, crime of all types is becoming globalized, seriously

${ }^{141}$ See supra note 118.

142 See LYNNE M. JURGIELEWICZ, GLOBAL ENVIRONMENTAL CHANGE AND INTERNATIONAL LAW: PROSPECTS FOR PROGRESS IN THE LEGAL ORDER (1996); THE EFFECTIVENESS OF INTERNATIONAL ENVIRONMENTAL AGREEMENTS: A SURVEY OF EXISTING LEGALINSTRUMENTS 437 (Peter H. Sand ed., 1992); see also Daniel Bodansky, The Legitimacy of International Governance: A Coming Challenge for International Environmental Law?, 93 AM. J. INT'L L. 596 (1999); Holley, supra note 118.

${ }^{143}$ See supra note 84.

${ }^{144}$ See supra note 15.

${ }^{145}$ See Child Online Protection Act, 47 U.S.C. $§ 231$ (1998); Reno v ACLU, 521 U.S. 844 (1997) (holding parts of the Communications Decency Act as unconstitutional); see also Jeff Magenau, Setting Rules in Cyberspace: Congress's Lost Opportunities to Avord the Vagueness and Overbreadth of the Communications Decency Act, 34 SANDIEGOL.REV 1111 (1997); Robert O'Neill, Free Speech on the Internet: Beyond "Indecency, " 38 JURIMETRICS 617 (1998); Junichı P Semitsu, Burning Cyberbooks in Public Librarles: Internet Filternng Software vs. The First Amendment, 52 STAN. L. REv 509 (2000); Symposium, Emerging Media Technology and the First Amendment, 104 YALE L.J. 1019 (1995); Vikas Arora, Note, The Communications Decency Act: Congressional Repudiation of the "Right Stuff," 34 HARV J. ON LEGIS. 473 (1997); Robert F 
undermining the idea of police work as a local or even as a national activity ${ }^{146}$ Similar problems are encountered with attempts to regulate the behavior of lawyers acting at a distance through the Internet. ${ }^{147}$ The increasing inability of nation-states to cope with the problems facing a globalizing society probably accounts for the emergence of regional groupings, such as the European Union, that appear to be gradually coalescing into entities capable of exercising sovereign powers to resolve regional problems. ${ }^{148}$ Yet the disintegration of formerly unified states, often

Goldman, Note, Put Another Log on the Fire, There's a Chill on the Internet: The Effect of Applying Current Anti-Obscenity Laws to Online Communications, $29 \mathrm{GA}$. L. REV 1075 (1995); Jill Jacobson, Comment, The Child Online Protection Act: Congress's Latest Attempt to Regulate Speech on the Internet, 40 SANTA CLARA L. REV 221 (1999); Phillip E. Lewis, Comment, A Brief Comment on the Application of the "Contemporary Community Standard" to the Internet, 22 CAMPBELL L. REV 143 (1999).

${ }^{146}$ See Raymond Bonner, F.B.I. Going to Budapest to Hunt the Mob, N.Y TIMES, Feb. 21, 2000, at A6 (reporting the opening of an FBI office in Budapest after the Hungarian government agreed that the officers would have authority to carry weapons and to make arrests). See generally Roger S. Clark, Crime: The UN Agenda on International Cooperation in the Criminal Process, 15 NoVA L. REV 475 (1991); William N. Gianarns, The New World Order and the Need for an International Crminal Court, 16 FORDHAM INT'L L.J. 88 (1992); Sandra L. Jamison, A Permanent International Criminal Court: A Proposal that Overcomes Past Objections, 23 DEN. J.INT'LL. \& POL'Y 419 (1995); Paul D. Marquardt, Law Without Borders: The Constitutionality of an International Crminal Court, 33 COLUM. J. TRANSNAT'L L. 73 (1995); Fazıa Patel, Crime Without Frontiers: A Proposal for an International Narcotics Court, 22 N.Y.U. J. INT'L L. \& POL. 709 (1990).

${ }^{147}$ See Brian G. Gilpın, Comment, Attorney Advertising and Solicitation on the Internet: Complying with Ethics Regulations and Netiquette, $13 \mathrm{~J}$. MARSHALL J. COMPUTER \& INFO. L. 697 (1995); Natacha O. Steimer, Note, Cyberlaw: Legal Malpractice in the Age of Online Lawyers, 63 GEO. WASH. L. REV 332 (1995); Daniel B. Kennedy, PCPractitioners Proliferate, A.B.A.J., June 1993, at 36; Ohio Lawyer May Render Legal Advice Through Law Firm's World Wide Web Site, 68 U.S.L.W.2388 (Jan. 11, 2000); Rosalind Resnick, A Shingle in Cyberspace, NAT’L L.J., Sept. 27, 1993, at 1.

${ }^{148}$ See FREDERICK M. ABBOTT, LAW AND POLICY OF REGIONAL INTEGRATION: THE NAFTA AND WESTERN HEMISPHERIC INTEGRATION IN THE WORLD TRADE ORGANIZATION SYSTEM (1995); DANIEL JUDAH ELAZAR, CONSTITUTIONALIZING GLOBALIZATION: THE POSTMODERN REVIVAL OF CONFEDERAL ARRANGEMENTS (1998); T.C. HARTLEY, THE FOUNDATIONS OF EUROPEAN COMMUNITY LAW: AN INTRODUCTION TO THE CONSTITUTIONAL AND ADMINISTRATIVE LAW OF THE EUROPEAN COMMUNTTY (4th ed. 1998); TOWARDS A EUROPEAN FOREIGN POLICY• 
with considerable bloodshed, demonstrates that political will can and does prevail over the apparent dictates of technology, even in quite small areas, as the problems in Lebanon, Northern Ireland, Yugoslavia, and the former Soviet Union have demonstrated. ${ }^{149}$

LEGAL, ECONOMIC, \& POLITICALDIMENSIONS (Johan K. De Vree et al. eds., 1987); Richard Bellamy \& Darno Castiglione, Building the Union: The Nature of Soveretgnty in the Political Architecture of Europe?, 16 LAW \& PHIL. 421 (1997); Marta Haines-Ferrarı, MERCOSUR: A New Model of Latin Amencan Economic Integration?, 25 CASE W RES. J. INT'L L. 413 (1993); Colin L. McCarthy, Regional Integration of Developing Countries at Different Levels of Economic Development-Problems and Prospects, 4 TRANSNAT'L L. \& CONTEMP PROBS. 1 (1994); Daniel T. Murphy, European Political Cooperation after the Single European Act: The Future of Foretgn Affatrs in the European Communities, 12 B.C. INT'L \& COMP L. REV 335 (1989); Horacio Grigera Naon, Soveretgnty and Regionalism, 27 LAW \& PoL'Y INT'L BUS. 1073 (1996); Catherıne Ruchmond, Preserving the Identity Criss: Autonomy, System and Soveretgnty in European Law, 16 LAW \& PHIL. 377 (1997); Martin Rudner, Institutional Approaches to Regional Trade and Cooperation in the Asta Pacific Area, 4 TRANSNAT'L L. \& CONTEMP PROBS. 159 (1994); Roger Cohen, A European Identity: Nation-State Losing Ground, N.Y TIMES, Jan. 14, 2000, at A3.

${ }^{149}$ See RICHARD HOLBROOKE, TO END A WAR (1998); U.N. PEACEKEEPING IN TROUBLE: LESSONS LEARNED FROM THE FORMER YUGOSLAVIA (Wolfgang Biermann \& Martin Vadset eds., 1998); Zaure Ayupova, The Republic of Kazakhstan: Six Years of Independent Development, 6 TULSA J. COMP \&INT'LL. 65 (1998); Stephen Dycus, Quebec Independence and United States Security: A Question of Continuing Rights and Duties, 15 ARIZ. J. INT'L \& COMP L. 187 (1998); Thomas D. Grant, A Panel of Expert for Chechnya: Purposes and Prospects in Light of International Law, 40 VA. J. INT'LL. 115 (1999); Thomas D. Grant, Comment, Territorial Status, Recognition, and Statehood: Some Aspects of the Genocide Case (Bosnia and Herzegovina v. Yugoslavia), 33 STAN. J. INT'LL. 305 (1997); Michael C. Hudson, The Breakdown of Democracy in Lebanon, $38 \mathrm{~J}$. INT'L AFF 277 (1985); Serge1 Khabarov, Introductory Note, 34 I.L.M. 1298 (1995); Martti Koskenniem1, The Future of Statehood, 32 HARV J. INT'L L. 397 (1991); Peter Margulies, Democratic Transitions and the Future of Asylum Law, 71 U. COLO. L. REV 3 (2000); Roger Myers, A New Remedy for Northern Ireland: The Case for United Nations Peacekeeping Intervention in an Internal Conflict, 11 N.Y.L. SCH. J. INT'L \& COMP L. 1 (1990); Babak Nikravesh, Quebec and Tatarstan in International Law, 23 FLETCHER F WORLD AFF 227 (Winter-Spring 1999); Sandra M. Saseen, The Taif Accord and Lebanon's Struggle to Regain Its Sovereignty, 6 AM. U.J. INT'L L. \& PoL'Y 57 (1990); Michael P Scharf, Musical Charrs: The Dissolution of States and Membership in the United Nations, 28 CORNELL INT'L L.J. 29 (1995); Aaron Schwabach, Environmental Damage Resulting from the NATO Military Action against Yugoslavia, 25 COLUM.J.ENTVL. 


\section{THE STRUCTURAL ALTERATION \\ OF INTERNATIONAL LEGAL PROCESSES}

International law long seemed relatively immune to the "deconstruction" that has become fashionable in certain circles of academic lawyering. ${ }^{150}$ International law and international legal processes largely escaped the "postmodernist" scrutiny because they were always less wedded to positivist notions of law that characterzzed the "modernist" vision of society ${ }^{151}$ This exemption from the postmodernist critique has now ended; postmodernusm has begun to appear in analyses of international law ${ }^{152}$ It is as true for international law as for other forms of law that "[i]n

L. 117 (2000); Symposium, Rethınking Nationalism and Sovereıgnty, supra note 15; Gregg R. Vetter, Command Responsibility of Non-Military Supenors in the International Criminal Court, 25 YALE J. INT'L L. 89 (2000); Sergel Vinogradov, Transboundary Water Resources in the Former Soviet Union: Between Conflict and Cooperation, 36 NAT. RESOURCES J. 393 (1996).

${ }^{150}$ See supra notes 39-70 and accompanying text.

${ }^{15 t}$ See CARTY, supra note 28, at 95-101, see also THOMAS M. FRANCK, THE POWER OF LEGITIMACY AMONG NATIONS (1990); Kenneth W Abbott, Modern International Relations Theory: A Prospectus for International Lawyers, 14 YALE J. INT'L L. 335 (1989); Philip Allott, Language, Method and the Nature of International Law, 45 BRIT. Y.B. INT'L L. 79 (1971); Douglas M. Johnston, Functionalism in the Theory of International Law, 26 CAN. Y.B.INT'LL. 3 (1988); Robert MacLean, Does Anyone Still Ask the Question "Is International Law Really Law? ", 1991 JURIDICAL REV., Pt. 2, at 230; James Brown Scott, The Legal Nature of International Law, 1 AM.J.INT'LL. 831 (1907); Alfred Verdross, Le Fondement du droit International, 16 RECUEIL DES COURS 251 (1927).

152 See CARTY, supra note 28; DE LUPIS, supra note 29; DAVID KENNEDY, INTERNATIONAL LEGAL STRUCTURE (1987); MARTTI KOSKENNIEMI, FROM APOLOGY TO UTOPIA. THE STRUCTURE OF INTERNATIONAL LEGAL ARGUMENT (1989); FRIEDRICH V KRATOCHWIL, RULES, NORMS, AND DECISIONS: ON THE CONDITIONS OF PRACTICAL ANDLEGALREASONINGININTERNATIONALRELATIONS AND DOMESTIC AFFAIRS (1989); NICHOLAS GREENWOOD ONUF, WORLD OF OUR MAKING: RULES AND RULE IN SOCIAL THEORY AND INTERNATIONAL RELATIONS (1989); James Boyle, Ideals and Things: International Legal Scholarship and the Prison-house of Language, 26 HARV.INT'LL.J.327 (1985); Ian Johnstone, Treaty Interpretation: The Authority of Interpretive Communities, 12 MICH.J.INT'LL. 371 (1991); Joel R. Paul, The New Movements in International Economic Law, 10 AM. U. J. INT'L L. \& POL'Y 607 (1995); Nigel Purvis, Critical Legal Studies in Public International Law, 32 HARV. INT'L L.J. 81 (1991); Daniel K. Tarullo, Logic, Myth, and the International Economic Order, 26 HARV.INT'LL.J. 533 (1985); Phillip R. Trumble, International Law, World Order, and Critical Legal Studies, 42 STAN. L. 
a period of rapid change, the older theories of legal legitimacy [sic], the meta-human theories, cannot sustain themselves."153 As a result, international law and international legal processes, as intellectual structures, are now open to question in a way that they were not open before. How scientific theory and technological applications affect an intellectual structure like law remains far from clear, except perhaps after the fact. The simplistic Marxian notion of "law as superstructure," with no reciprocal effect on the social structures reflected in the law, can no longer be maintained. ${ }^{154}$ Nor can one simply accept the Weberian notion that law (and other ideological constructs) creates the material society within which the law functions. ${ }^{155}$ Law both affects and reflects changes in the society which it governs, by legitimating changes in certain (not always foreseen) directions and by recognizing as legitimate changes that have already occurred.

The most fundamental changes in society can be expected to bring about the most fundamental changes in law, even acknowledging the effects of law in channeling or otherwise controlling such changes. For example, the invention of clear glass in thirteenth-century Italy led to glass

REV 811 (1990); G. Webb, Symbols and Ideas-Rules, Gutdelines and International Law, 14 VICTORIA UNIV WELLINGTONL. REV. 389 (1984); Kenneth L. Wise, Social Science and Global Law, 14 CREIGHTON L. REV 1355 (1981); Jason Mark Anderman, Note, Swrmming the New Stream: The Disjunctions Between and Within Popular and Academic International Law, 6 DUKE J. COMP. \& INT'L L. 293 (1996); see also Günter Frankenberg, Critical Comparisons: Rethinking Comparative Law, 26 HARV INT'L L.J. 411 (1985).

${ }^{153}$ LAWRENCE M. FRIEDMAN, THE REPUBLIC OF CHOICE: LAW, AUTHORITY, AND CULTURE 53 (1990).

${ }^{154}$ See Karl MarX, Critique of tHe Gotha PROGRaM (reprinted 1987) (1875). Compare P.I. STUCKA, THE OVERTHROW OF LAW (1919), with KARL RENNER, THE INSTITUTIONS OF PRIVATE LAW aNd THEIR SOCIAL FunCtions (1929). See also L1 Buyun, Certain Questions Concerning the Relationship between Party Polictes and State Laws, 3 FAXUE JIKAN 3 (July 1984) (in Chinese); Wu Jianfan, Building New China's Legal System, 22 COLUM. J. TRANSNAT'L L. 1 (1983); see generally MAUREEN CAIN \& ALANHUNT, MARXAND ENGELS ONLAW (1979); Alice Erh-Soon Tay \& Eugene Kamenka, Marxism, Socialism and the Theory of Law, 23 CoLUM. J. TRANSNAT'L L. 217 (1985).

155 See MAX WEBER ON LAW IN ECONOMY AND SOCIETY (Max Rheinstem ed. \& Edward Shils trans., 2d ed. 1954); MAX WEBER, THE SOCIOLOGY OF RELIGION (Ephraim Fischoff trans., 4th ed. 1963) (1922); see also J.M. BALKIN, CULTURAL SOFTWARE: A THEORY OF IDEOLOGY (1998); REINHARD BENDIX, MAXWEBER:AN INTELLECTUAL PORTRAIT (1960); PETER STEIN \& JOHN SHAND, LEGAL VALUES IN WESTERN SOCIETY (1974). 
windows which not only radically altered Western painting (frames and perspectives) but also distanced the viewer from the view This transformed the way Europeans (and eventually all people) related to the world. ${ }^{156}$ Similarly, the perfection of mechanical clocks in medieval monastenes (as a means of assurning timely prayers) revolutionized the way we structure time, eventually leading to the assembly line and modern science. ${ }^{157}$ For law, such changes were profound; even more immediately profound were the transitions in the medium whereby lawyers function, from oral law to scribal law to printed law ${ }^{158}$ Today, we face the transition to electronic media, producing what some have termed "paratexts," which again could revolutionize the very intellectual structure of law ${ }^{159}$

International law is, in some ways, a problematic discipline. International law and its processes are a decentralized and highly informal system, one that can farrly be described as primitive. ${ }^{160}$ By the word "primitive,"I (and presumably others who use this word to describe international law and legal processes) do not mean to suggest that international law is always ineffective or unsophisticated. Rather, the international legal system is highly decentralized and institutionally undeveloped. In such a system, law can easily become a "language of moralistic reproach," or a means of

${ }^{156}$ See MUMFORD, supra note 34 , at $124-31$.

${ }^{157}$ See id. at $12-17$

${ }^{158}$ See infra notes 164-193 and accompanying text; see also Collins \& Skover, supra note 1. See generally Robert K. Logan, The Alphabet Effect: The Impact of the Phonetic Alphabet on the Development of Western Civilization (1986); Marshall McLuhan, The Gutenberg Galaxy• The Makung of Typographic Man (1962); ONG, INTERFACES OFTHE WORD, supra note 40; WALTERJ. ONG, ORALITY AND LITERACY: THE TECHNOLOGIZING OF THE WORD (1982) [heremafter ONG, ORALITY AND LITERACY]; WALTER J. ONG, RHETORIC, ROMANCE, AND TECHNOLOGY: STUDIES IN THE INTERACTIONOF EXPRESSION AND CULTURE (1971); BERTHOLD L. ULLMAN, ANCIENT WRITING AND ITS INFLUENCE (1932).

${ }^{159}$ See Collins \& Skover, supra note 1, at 535-52. See generally MARSHALL MCLUHAN, UNDERSTANDING MEDIA. THE EXTENSIONS OF MAN (1964).

${ }^{160}$ See J.L. BRIERLY, THE LAW OF NATIONS: AN INTRODUCTION TO THEINTERNATIONAL LAW OF PEACE 71-78 (5th ed. 1963); H.L.A. HART, THE CONCEPT OF LAW 89-91 (1961); HANS KELSEN, ANINTRODUCTIONTOTHEPROBLEMS OFLEGAL THEORY 108-09 (Bonnie Litschewskı Paulson \& Stanley Paulson trans., 1992); HANS J. MORgENTHAU, POLITICS AMONG NATIONS: THE STRUGgLE FOR POWER AND PEACE 265 (4th ed. 1967) (1948); Yoram Dinstein, International Law as a Primitive Legal System, 19 N.Y.U. J. INT'L L. \& POL. 1 (1986). But see B.S. CHIMNI, INTERNATIONAL LAW AND WORLD ORDER: A CRITIQUE OF CONTEMPORARY APPROACHES 47-55 (1993); A.I.L. Campbell, International Law and Primitive Law, 8 OXFORD J. LEG. STUD. 169 (1988). 
cloaking national interest in apparently neutral normative terms, or even "the concealment of factual changes with legal fictions."161 Worst of all, international law can appear to vacillate between pure "scholasticism in the face of urgent practical problems, and of the facile application of general rules without a deep understanding of situations that are unique."162 International law is so primitive that many. still question whether it deserves to be called law ${ }^{163}$ One cannot overlook these limitations of international law and its processes when considering how it might change and is changing in response to the impacts of science and technology

To examine the changes in international law and its processes as intellectual structures, I begin with a discussion of how technology has affected law in general. Then I will focus on the specific interaction between the intellectual structure of international law and its processes and contemporary changes in science and technology Hopefully, in this way we can arrive at some conclusions about where international law and its processes are headed. We may even get some idea about where law in general is headed.

\section{A. How Law is Bound by Its Form}

Law has taken different forms in different times and places, and it has played different roles in different cultures. ${ }^{164}$ Here, I want us to consider the

${ }^{161}$ Adam Roberts, Prolonged Military Occupation: The Israeli-Occupled Termtornes Since 1967, 84 AM. J. INT'L L. 44, 45 (1990).

${ }^{162}$ Id.

163 The question has been asked increasingly emphatically at least since John Austin in the nineteenth century. $C f$. JOHN AUSTIN, THE PROVINCE OF JURISPRUDENCE DETERMINED AND THE USES OF THE STUDY OF JURISPRUDENCE 122-25 (1954) (1863). See generally HANS KELSEN, PRINCIPLES OF INTERNATIONAL LAW 18-89 (1952); MALCOLM N. SHAW, INTERNATIONAL LAW 2-12 (1977); MacLean, supra note 151, Scott, supra note 151, Glanville L. Williams, International Law and the Controversy Concerning the Word "Law," 22 BRT. Y.B. INT'L L. 146 (1945); Robert O. Keohane, Comment, International Relations and International Law: Two Optics, 38 HARV INT'L L.J. 487 (1997); Thomas K. Plofchan, Jr., Note, A Concept of International Law: Protecting Systemic Values, 33 VA. J. INT'L L. 197 (1992).

${ }^{164}$ See generally MARTIN CHANOCK, LAW, CUSTOM, AND SOCIAL ORDER: THE COLONIAL EXPERIENCE IN MALAWI AND ZAMBIA (1985); JOHN M. CONLEY \& WILLIAM M. O'BARR, RULES VERSUS RELATIONSHIPS: THE ETHNOGRAPHY OF LEGALDISCOURSE (1990); NOELJ. COULSON, CONFLICTS AND TENSIONIN ISLAMIC JURISPRUDENCE (1969); EUGEN EHRLICH, GRUNDLEGUNG DER SOZIOLOGIE DES 
ways in which law was recorded and recalled. Initially, law arises in oral cultures without written records ("oral law"). Later, with the invention of writing but with writing remaining a scarce and expensive craft, some aspects of law are written down by those possessing the secret of writing for reference on special occasions ("scribal law"). With the invention of printing and the spread of literacy, more law is written down, and it is accessible to anyone willing to devote humself or herself to mastering the researching and the reading of the materials ("printed law"). Finally, in recent decades we have begun to store and retrieve legal materials through electronic means, making the materials available to anyone with a computer ("digital law").

I do not suggest that there is a precise timetable for transitions from one stage to another. Different societies have entered upon these distinct techniques for storing and retrieving law at different times and at different rates. Nor do I mean to suggest that any of these techniques is "better" than another technique. They are simply different, and they succeed each other in time. Furthermore, in significant respects each of the earlier stages has persisted even after the later stage has become dominant in a particular society The functioning and effects of each technique deserves a brief analysis.

\section{Oral Law}

Oral law depends on ritual and ceremony to manage society, with collective memory (often physically embodied in a "lawspeaker") of customary practices providing the link of past to present. ${ }^{165}$ This customary law was highly flexible, particularly as the claim that a practice existed from "before living memory" might mvolve a period as short as twenty years in a society wholly dependent on oral tradition, and given the

RECHTS (1929); ROBERT C. ELLICKSON, ORDER WTTHOUT LAW: HOW NEIGHBORS SETTLE DisPUTES (1991); HistoRY AND POWER IN THE STUDY OF LAW· NEW DIRECTIONS IN LEGAL ANTHROPOLOGY 252, 267 (June Starr \& Jane Collier eds., 1989); VICTOR H.LI, LAW WITHOUT LAWYERS: A COMPARATIVE VIEW OF LAW IN CHINA AND THE UNITED STATES (1978); SALLY ENGLE MERRY, GETTING JUSTICE AND GETTING EVEN:LEGALCONSCIOUSNESS AMONG WORKING-CLASS AMERICANS (1990); SALLY FALKMOORE,LAW AS PROCESS: ANANTHROPOLOGICALAPPROACH (1978); EVERETT M.ROGERS, DIFFUSIONOFINNOVATIONS (1962); Alan Hyde, The Concept of Legitimuzation in the Sociology of Law, 1983 WIS. L. REV 379; Elihu Katz, Theorizing Diffusion: Tarde and Soroknn Revisited, 566 ANNALS AM. ACAD. PoL. \& SoC. SCI. 144 (1999).

${ }^{165}$ See Collins \& Skover, supra note 1, at 516-21. 
tendency to describe all innovations as if they were merely the established custom. ${ }^{166}$ Being without a written text, oral law was living law, localized and contextualized, without a hierarchical bureaucracy ${ }^{167}$ Law was considered to be a product of society's "common conscience rather than primarily as a deliberate expression of conscious reason or of will."168 In sum, oral jurisprudence "was the expression of needs rather than of knowledge."169

\section{Scribal Law}

The reduction of law to written forms began at about the same time that the leading religions began to take written form. Indeed, the earliest written statements of law-as with the Code of Hammurabl - were contained in what were essentially religious documents. ${ }^{170}$ The development of written records of religious and legal duties initially was a very limited process, affecting few societies and even fewer people within those societies. Then, quite suddenly, within a space of the few decades between 550 and 450 B.C.E., all the religious and philosophical traditions that in coming centuries would have global significance were codified in writing. ${ }^{171}$

The introduction of writing, for those exposed to it, transformed their perception of the world every bit as much as the development of glass windowpanes. ${ }^{172}$ Knowledge became fixed in the written word, to be

${ }^{166}$ See MARC BLOCH, FEUdAL SOCIETY 114 (L.A. Manyon trans., 1961); ERIC A. HAVELOCK, PREFACE TO PLATO 121 (1963); FRITZ KERN, KINGSHIP AND LAW IN THE MIDDLE AGES 179 (S.B. Chrimes trans., 1939).

${ }^{167}$ See Collins \& Skover, supra note 1, at 520 .

${ }^{168}$ Harold J. Berman, The Background of Western Legal Tradition in the Folklaw of the Peoples of Europe, 45 U. CHI. L. REV 553, 577 (1978).

${ }^{169}$ BLOCH, supra note 166, at 114; see also HAVELOCK, supra note 166, at 122. ${ }^{170} \mathrm{See}$ C.H.W JOHNS, BABYLONIAN AND ASSYRIAN LAWS, CONTRACTS AND LETTERS (1999).

${ }^{171}$ See A.C. BHAKTIVENDANTA SWAMIPRABHUPADA, THEBHAGAVID-GITÄAS IT Is (1972) (Hindusm); A SOURCE BOOK IN CHINESE PHILOSOPHY (Wing-Tsit Chan ed. \& trans., 1963) (Confucianısm; Dao1sm); ENTERING THE STREAM: AN INTRODUCTION TO THE BUDDHA AND HIS TEACHINGS (Samuel Bercholz \& Sherab Chödzın Kohn eds., 1993) (Buddhism); Great Dialogues of Plato (Enic Warmington \& Philip Rouse eds., W.H.D. Rouse trans., 1956) (Platonism); Ezekel, Isazah, \& Jeremiah (Judaism); A.V WILLAMS JACKSON, ZOROASTER: THE PROPHET OF ANCIENT IRAN (1898) (Zoroastranism).

172 See ONG, INTERFACES OF THE WORD, supra note 40; ONG, ORALITY AND LITERACY, supra note 158; WALTER J. ONG, THE PRESENCE OF THE WORD (1967) 
analyzed, articulated, defined, and explained. ${ }^{173}$ The etymology of these words suggests clearly how the advent of writing, even in its most incipient form, transformed the human relation to the world. "Analyze" comes from the Greek ana-liein, to break into parts. "Articulate" comes from the Latin articulare, to join, here through proper grammar and syntax. "Define" comes from the Latin definire, to draw a line around. "Explain" comes from the Latin, explanare, to lay out on the surface.

A text became a monument of one's thought, but a monument that was abstracted from context. ${ }^{174}$ The text became its own world, with the writing or reading subject sharply differentiated from the object of knowledge. ${ }^{175}$ As the eye can only look upon what is other than itself, reality became objectified. ${ }^{176}$ With the writer seeing but unseen, the objective form of discourse became possible in which the subject of the knowledge appears to disappear. ${ }^{177}$

In other words, a text becomes authoritative when it appears to speak in universal and abstract terms. As one observer summanized the resulting transformation, for a text to speak, the author must be silent. ${ }^{178}$ The desire to achreve universal validity perhaps explains why so many religious or philosophical traditions began to formulate definitive texts within such a brief span of time once it became possible to do so. It also probably explains why laws also began to be codified-including the " 12 Tables" of the decemvir in Rome, codified between 451 and 449 B.C.E. which became the fount of the most influential legal tradition in human history ${ }^{179}$

The reduction of law to written form, even before printing, so fundamentally transformed it that, in the view of some, "the history of law begins with the written word." 180 Law professors Ronald Collins and

[heremafter ONG, PRESENCE].

${ }^{173}$ I take these examples from Matthew A. Ritter, The Penile Code: The Gendered Nature of the Language of Law, 2 N.Y CITY L. REV 1, 5-6 (1998).

${ }^{174}$ See ONG, PRESENCE, supra note 172, at 116.

${ }^{175}$ See id. at 135-36.

176 See id. at 228.

${ }^{177}$ See ONG, INTERFACES OF THE WORD, supra note 40, at 121-22.

${ }^{178}$ See Ritter, supra note 173, at 7

179 See BARRY NICHOLAS, AN INTRODUCTION TO ROMAN LAW 3-14 (1969).

${ }^{180}$ WILLIAM SEAGLE, MEN OF LAW: FROM HAMMURABI TOHOLMES 12 (1947). Note also that Shakespeare follows his famous line about killing all the lawyers with the rebel Cade's discourse on the evils of allowing parchment "to undo a man." Later, Cade commands his followers to burn all the records of the realm. WILLIAM SHAKESPEARE, THE SECOND PART OF KING HENRY THE SIXTH act 4, scs. 2,7 
David Skover summanzed this transformation only slightly differently when they wrote, "the story of law is one of distancing text from context." "181 Writing law down fixed it, makng future change both more difficult and more conscious. ${ }^{182}$ Writing also made law a "one-way conversation" between the law-giver and those subject to the law, extending the spatial and temporal reach of law by transforming law into a thing to be studied and decoded. ${ }^{183}$ Written law is abstract law, with the individual stripped away to focus on general and even universal relations. ${ }^{184}$ Scribal law did not take complete hold of legal procedure, however, if only because most people could neither read nor write and retanned an abıding distrust of the authenticity and reliability of writing. ${ }^{185}$

\section{Printed Law}

Only with the advent of the ability to make exact reproductions of innumerable copies of a text and the emergence of mass literacy, both possible only following the development of movable type, could the attributes of written law truly take hold. ${ }^{186}$ The transition to printed law was not without controversy ${ }^{187}$ Those who opposed the printing of English legal materials did so on the ground that it would vulgarize the law by opening it to influence and pressure from the popular culture once law books became available to the general public. ${ }^{188}$ In the end, the desire for administrative efficiency and popular legitimacy won out.

${ }^{181}$ Collins \& Skover, supra note 1 , at 521.

${ }^{182}$ As Chief Justice Camden expressed it: "[I]f this is law, it would be found in our books. If it is not to be found there, it is not law." Entick v. Carrington, 19 Howell's St. Tr. 1029, 1066 (K.B. 1765) (quoted in Collins \& Skover, supra note 1 , at 529).

${ }^{183}$ See Collins \& Skover, supra note 1, at 521-29; BRIAN STOCK, THE IMPLICATIONS OF LITERACY: WRITTENLANGUAGE AND MODELS OF INTERPRETATION IN THE ELEVENTH AND TWELFTH CENTURIES (1983); see also MCLUHAN, supra note 159.

${ }^{184}$ See JACK GOODY, THE INTERFACE BETWEEN THE WRITTEN AND THE ORAL 75 (1987).

${ }^{185}$ See M.T.CLANCHY,FROMMEMORYTO WRTTENRECORD: ENGLAND, 10661307, at 208-11 (1979).

${ }^{186}$ See Collins \& Skover, supra note 1, at 529-35.

${ }^{187}$ See Richard J. Ross, The Commoning of the Common Law: The Renaissance Debate over Printing English Law, 1520-1640, 146 U. PA. L. REV 323 (1998).

${ }^{188}$ See id. at 380-86. 
A printed page's borders frame reality much like a window, pushing the individual and her full life expenence right off the page. Ethan Katsh has summarized the impact of the printed word in these words:

[T] expression "in print" is more than a factual statement of where a prece of information is located. In addition, the expression indicates to us that the work is no longer readily changeable, that it has been bound and cannot be unbound, that every available copy is the same as every other copy, and that each copy will have those familiar identifying characteristics such as a title page, copynght notice, justified margins, and index, characteristics that communicate in a visual way that the information is in final form. ${ }^{189}$

Having confined its subjects, the printed text permits one to categorize and organize them through glossanes, indices, tables of contents, and headings. ${ }^{190}$ In short, "[p]nnt maximized the manuscrupt's power by minimizing its weaknesses." ${ }^{.191}$ Just as the advent of the printed Bible permitted a reformation of the manner in which the individual related to the "word of God,"192 printing also remade the relationship between individuals and the law Law became a monopoly of the state as it sought to centralize all authority and, through law, to compel all persons within the state to conform to a single standard of governmentally prescribed conduct. ${ }^{193}$

\section{Digital Law}

If these ideas about the impact of the dominant forms of communication in society on law and legal systems are correct, then the introduction of computerization should bring about another grand transformation in society and in law Perhaps a clue about what is happening in this regard is a comment made by comedian Jay Leno: "We've reached a point where

${ }^{189}$ M. Ethan Katsh, Law Reviews and the Migration to Cyberspace, 29 AKRON L. REV 115, 119 (1996) [hereinafter Katsh, Law Reviews].

${ }^{190}$ See Collins \& Skover, supra note 1 , at 530.

${ }^{191}$ Id. , see also FLORIAN COULMAS, THE WRITING SYSTEMS OF THE WORLD $11-$ 14 (1989); ELIZABETHEISENSTEIN, THEPRINTING REVOLUTIONINEARLYMODERN EUROPE 63, 72-74, 79-80, 83 (1983); KATSH, THE ELECTRONIC MEDIA, supra note 16, at 33-35, 85-86, 215-18; MCLUHAN, supra note 159, at 125, 156.

192 EISENSTEIN, supra note 191, at 147; LOGAN, supra note 158, at 217-23.

${ }^{193}$ See generally EISENSTEIN, supra note 191, HAROLD A. INNIS, EMPIRE AND COMMUNICATIONS (1972). 
Congress does not affect anyone's life, so we look at it as entertainment."194 Indeed, the 1990s have seen a remarkable wave of constitutional transformations across the globe. ${ }^{195}$ Nothing comparable has been seen in the world since the "Age of Democratic Revolution" some two centuries earlier and the rise of totalitananism in the early twentieth century ${ }^{196}$ The era that ushered in the Amencan and French Revolutions correlated with the transformation of cultures and legal systems from scribal to printed forms. The revolutionary transformations signaled by the Mexican, the Russian, and the Naz1 Revolutions could be seen as the final gasp of the attempt to create a centralized, idealized system characteristic of printed law Today, most of the planet seems to be moving in a different direction.

Lookng more specifically at the law and legal systems of today, we find a fundamental transformation in the way law is recorded and enacted. ${ }^{197}$ Even with the considerable debate surrounding the merits of

${ }^{194}$ Howard Kurtz, Americans Wait for the Punch Line on Impeachment, WASH. PosT, Jan. 26, 1999, at A1.

${ }^{195}$ See Bruce Ackerman, The Rise of World Constitutionalism, 83 VA. L. REV 771 (1997); Mark Tushnet, Foreword: The New Constitutional Order and the Chastening of Constitutional Aspiration, 113 HARV L. REV 29 (1999); see also Lawrence Lessig, Reading the Constitution in Cyberspace, 45 EMORY L.J. 869 (1996).

196 See generally CRANE BRINTON, THE ANATOMY OF REVOLUTION (1938); HECTOR AGUILAR CAMIN \& LORENZO MEYER, IN THE SHADOW OF THE MEXICAN REVOLUTION: CONTEMPORARYMEXICANHISTORY, 1910-1989 (Lu1s Alberto Fierto trans., 1993); ORLANDOFIGES, APEOPLE'S TRAGEDY; THERUSSIANREVOLUTION, 1891-1924(1997);E.J.HOBSBAWM, THE AGE OF REVOLUTION:EUROPE 1789-1848 (1962); R.R. PALMER, THE AGE OF DEMOCRATIC REVOLUTION: A POLITICAL HISTORY OF EUROPE AND AMERICA, $1760-1800$ (1959); WILLIAM L. SHIRER, THE RISE AND FALL OF THE THIRD REICH: A HISTORY OF NAZI GERMANY (1960).

${ }^{197}$ See G. BURGESS ALLISON, THE LAWYER'S GUIDE TO THE INTERNET (1995); CAVAZOS \& MORIN, supra note 89; KATSH, THE ELECTRONIC MEDIA, supra note 16; EDKROL, THE WHOLE INTERNET USER'S GUIDE ANDCATALOG(1995); DANIEL E. ROSE, A SYMBOLIC AND CONNECTIONIST APPROACH TO LEGAL INFORMATION RETRIEVAL (1994); Brickner, supra note 6; Collins \& Skover, supra note 1, at 53552; John King Gamble, Broadening Access to International Law Resources through New Technology, 82 AM. SOC'Y INT'L L. 1 (1995); John King Gamble, International Law and the Information Age, 17 MICH. J. INT'L L. 747 (1996); Francis A. Gilligan \& Edward J. Imwinkelried, Cyberspace: The Newest Challenge for Traditional Legal Doctrine, 24 RUTGERS COMPUTER \& TECH. L.J. 305 (1998); Graham Greenleaf et al., Representing and Using Legal Knowledge in Integrated Decision Support Systems: DataLex Work Stations, 3 ARTIFICIALINTELLIGENCE \& L. 97 (1995); Marc Lauritsen, Technology Report: WorkProduct Retrieval Systems 
televising actual legal proceedings, ${ }^{198}$ several courts have begun to cablecast therr proceedings over the Internet, creating virtual courtrooms. ${ }^{199}$

in Today's Law Offices, 3 ARTIFICIAL INTELLIGENCE \&L. 287 (1996); Philip Leith, The Judge and the Computer How Best "Decision Support"?, 6 ARTIFICIAL INTELLIGENCE \& L. 289 (1998); Douglas E. Litowitz, Has Technology Improved the Practice of Law?, 21 J. LEGAL PROF 51 (1997); Henry Prakken \& Giovannu Sartor, Modelling Reasoning with Precedents in a Formal Dialogue Game, 6 ARTIFICIAL INTELLIGENCE \& L. 231 (1998); G. Sartor \& L. Karl Branting, Introduction: Judictal Applications of Artifictal Intelligence, 6 ARTIFICIAL INTELLIGENCE \& L. 105 (1998); Uri Schild, Criminal Sentencing and Intelligent Decision Support, 6 ARTIFICIAL INTELLIGENCE \& L. 151 (1998); J.C. Smith et al., Artifictal Intelligence and Legal Discourse: The Flexlaw Legal Text Management System, 3 ARTIFICIAL INTELLIGENCE \& L. 55 (1995); Symposium, Courtroom 2000: Technology and the Legal System, 25 OHIO N.U.L. REV 523 (1999); Cyrus Tata, The Application of Judicial Intelligence and "Rules" to Systems Supporting Discretionary Judicial Decision-Makng, 6 ARTIFICIAL INTELLIGENCE \& L. 203 (1998); Howard Turtle Text Retreval in the Legal World, 3 ARTIFICIAL INTELLIGENCE \& L. 5 (1995); Eugene Volokh, Computer Media for the Legal Profession, 94 Mich. L. REV 2058 (1996); Wassom, supra note 6; Timothy Q. Delaney, Coming Clean on E-Mail Discovery: Soap Giant Proctor \& Gamble, Amway Battle Shows Need for Clear Rules, A.B.A. J., Dec. 1999, at 74; William C. Glessner, III, Laptop Litigation: Electronic Advocacy Utilizing Summation ${ }^{\circledast}$, Tral Director ${ }^{\circledR}$ and Microsoft Office $97^{\circledR}, 43$ TRIAL LAW. GUIDE 1 (1999); Mark Grossman, Cyberlaw: Lawyers Look for the Cutting Edge, LEGAL TIMES, May 24, 1999, at 25; Hope Viner Samborn, Colleagues in Space: Online Discussion Groups Prove Unıquely Informative - and Addictive, A.B.A. J., Dec. 1999, at 80; Taylor, supra note 6 . Law, of course, is not the only profession facing dramatic transformations as a result of the digitalization of information. See Gina Kolata Web Research Transforms Visit to the Doctor, N.Y. TIMES, Mar. 6, 2000, at A1 (describing how the Internet has changed the relationship between doctor and patient).

${ }^{198}$ See RONALD L. GOLDFARB, TV OR NOT TV · TELEVISION, JUSTICE, AND THE CoURTS (1998); Jay C. Carlisle, An Open Courtroom: Should Cameras Be Permitted in New York State Courts, 18 PACE L. REV 297 (1998); Rebecca Leigh Cassal, Cameras in the Courtroom, FED. LAW., Sept. 1999, at 22.

${ }^{199}$ See Hope Viner Samborn, Plenty of Seats in Virtual Courtrooms: 'Webcasts' of Judicial Proceedings Gaining-and Educating - a Wide Audience, A.B.A. J., Feb. 2000, at 68, listing these websites: $<$ www.flcourts.org/courts/supct $>$ [Fla. Sup. Ct.]; <www.law.emory.edu/LAW/SupremeCourt.html> [Ga. Sup. Ct.]; <www. municipalcourt.org $>$ [Del. (Ohio) Mun. Ct.]; <www.ninja9.org/courtadmın/mis/ courtroom_23.htm> $>$ Fla. Ct. App.9th Cir.]; <www.state.m.us> [Ind. Sup.Ct.]; see also Frank Conley, -) Service with a Smiley: The Effect of E-Mail and Other Electronic Communications on Service of Process, 11 TEMPLE INT'L \& COMP.L.J. 
Even without broadcasting (or narrowcasting), video processes are transforming the trial process. A videotaped record of a trial, of "a day in the life" of an accident victim, of a will, or of a legislative session, or even computer-animated modeling, ${ }^{200}$ all serve to recontextualize law and the persons involved with legal proceedings. ${ }^{201}$ The United States Supreme

407 (1997); Jessica R. Herrera, Litigators Benefit as More Courts Open Websites: Internet Provides Quick Information; Permits Electronıc Filing, LITIG. NEWS, May 1999 , at 5.

${ }^{200}$ See Constantino v. Herzog, 203 F.3d 164 (2d Cir. 2000) (holding a videotape used to train physicians on a particular medical procedure admissible under the "learned treatise" exception to the hearsay rule); James E. Carbine \& Lynn McLain, Proposed Model Rules Governing the Admussibility of ComputerGenerated Evidence, 15 SANTA CLARA COMPUTER \& HIGH TECH. L.J. 1 (1999); James I. Keane, Prestidigitalization: Magıc, Evidence and Ethics in Forensic Digital Photography, 25 OHIO N.U. L. REV 585 (1999); Frednc I. Lederer, Some Thoughts on the Evidentiary Aspects of Technologically Presented or Produced Evidence, 28 Sw. U. L. REV 389 (1999); L. Matthew Springer, Comment, A Far Cry from Katz: Deciding the Constitutionality of Prewarrant Thermal Imaging, 25 OHIO N.U. L. REV 593 (1999); Michael V Ciresı \& Jan M. Conlin, A High-Tech Case: Lessons from Honeywell v. Minolta, TRIAL, Sept. 1992, at 22; Fred I. Heller, The Televised Witness: Preparing Videotapted Depositions, TRIAL, Sept. 1992, at 50; Ralph A. Taylor, Jr., Visual Persuaston in the Courtroom: Tips for More Effective Tral Presentation, 25 LITIG. NEWS, Jan. 2, 2000, at 12.

${ }^{201}$ See GREGORY P JOSEPH, MODERN VISUAL EVIDENCE (1984); ASHLEY S. LIPSON, ART OF ADVOCACY:DEMONSTRATIVEEVIDENCE (1999); Karen D.Butera, Seeing Is Believing: A Practitioner's Gulde to the Admissibility of Demonstrative Computer Evidence, 46 CLEV ST. L. REV 511 (1998); Timothy W Cerniglia, Computer-Generated Exhibits-Demonstrative, Substantive or Pedagogical -Their Place in Evidence, 18 AM. J. TRIAL ADVOC. 1 (1994); I. Neel Chatterjee, Admitting Computer Antmations: More Caution and New Approach Are Needed, 62 DEF COUNS. J. 36 (1995); Richard M. Dunn \& Christopher D. Brown, Some Suggestions on Admitting Computer Graphics into Evidence at Tral, 65 DEF CouNS. J. 526 (1998); Kathlynn G. Fadely, Use of Computer-Generated Visual Evidence in Aviation Litigation: Interactive Video Comes to Court, 55 J. AIR L. \& COM. 839 (1990); Samuel A. Guiberson, Technology and Advocacy in the New Technology Courtroom, 28 Sw. U. L. REV 405 (1999); Stanley A. Kurzban, Authentication of Computer-Generated Evidence in the United States Federal Courts, 35 IDEA 437 (1995); Linda C. Morell, New Technology: Experimental Research on the Influence of Computer-Animated Display on Jurors, 28 SW U.L. REV 411 (1999); Craig Murphy, Computer Simulations and Video Re-enactments: Fact, Fantasy and Admission Standards, 17 OHION.U.L.REV 145 (1990); Adam T. Berkoff, Comment, Computer Simulations in Litigation: Are Television Generation Jurors Being Misled?, 77 MARQ. L. REV 829 (1994); Elame M. 
Court has already begun to refashion the constitutional commands regarding evidence to reflect the availability of electronic media. ${ }^{202}$ On the other hand, computerized indexing and the possibility of rules restricting

Chaney, Note, Computer Simulations: How They Can Be Used at Trial and the Arguments for Admussibility, 19 IND. L. REV 735 (1986); Patnck R. Grady, Comment, Discovery of Computer Stored Documents and Computer Based Litigation Support Systems: Why Give up More than Necessary, 14 J. MARSHALL J. COMPUTER \& INFO. L. 523 (1996); Paul F Eckstein \& Samuel A. Thumma, Getting Sclentific Evidence Admitted: The Daubert Hearng, LITIG., Winter 1998, at 21. See generally EDWARDR. TUFTE, ENVISIONING INFORMATION (1990); Frank Andrews, Computer-Integrated Courtrooms: Enhancing Advocacy, TRIAL, Sept. 1992, at 37; George P Field, Using a Computer at Counsel Table, TRIAL, Sept. 1992, at 30; Ruchard Ryan Lamb, When Courts Videotape Proceedings, TRIAL, Sept. 1992, at 44; Willis H. Ricc1o, Securities Litigation and Computer-Generated Evddence, R.I. B.J., Feb. 1998, at 17; Heywood Waga, New Court Reporting Systems, TRIAL, Sept. 1992, at 40.

${ }^{202}$ See Maryland v. Cra1g, 497 U.S. 836 (1990) (permitting the use of one-way closed-circuit television for the presentation of a child's testimony in a child abuse prosecution); see also People v. McHugh, 476 N.Y.S.2d 721 (Sup. Ct. 1984) (approving the use of computer animation as evidence in a prosecution for vehıcular homıcide). See generally Josephine A. Bulkey, Recent Supreme Court Decisions Ease Child Abuse Prosecutions: Use of Closed-Circuit Televiston and Children's Statements of Abuse Under the Confrontation Clause, 16 NOVAL. REV 687 (1992); Richard L. Marcus, Completing Equity's Conquest? Reflections on the Future of Tral under the Federal Rules of Civil Procedure, 50 U. PITT. L. REV 725, 745-49 (1989); John B. Mitchell, What Would Happen if Videotaped Depositions of Sexually Abused Children Were Routinely Admitted in Civil Suits? A Journey Through the Legal Process and Beyond, 15 U. PUGET SOUND L. REV 261 (1992); Nancy Schleifer, Might versus Fright: The Confrontation Clause and the Search for "Truth" in the Child Abuse Family Court Case, 16 NOVA L. REV 783 (1992); Clive Walker, Fundamental Rights, Fair Trals and the New AudioVisual Sector, 59 MOD. L. REV 517 (1996); Peter T. Wendel, A Law and Economics Analysis of the Right to Face-to-Face Confrontation Post-Maryland v. Cra1g: Distinguishing the Forest from the Trees, 22 HoFSTRA L. REV 405 (1993); Bryan H. Wildenthal, The Right of Confrontation, Justice Scalia, and the Power and Limits of Textualism, 48 WASH. \& LEE L. REV 1323 (1991).

The new technologies also give nise to disturbing problems about the ability of the government to search or sezze digital data. See 18 U.S.C. $\$ \S 2510-2522$ (1998); Gilligan \& Imwinkelried, supra note 197; Raphael Winıck, Searches and Selzures of Computers and Computer Data, 8 HARV J.L. \& TECH. 75 (1994); Michael Adler, Note, Cyberspace, General Searches, and Digital Contraband: The Fourth Amendment and the Net-Wide Search, 105 YALE L.J. 1093 (1996). 
the extent that electronic records are received into evidence permit the kind of systemized closure characteristic of printed law

At the end of the day digital law challenges nearly all of our established notions regarding boundares ${ }^{203}$ It not only erodes political boundaries, but it erodes economic and intellectual ones as well.$^{204}$ Placing information on the Internet, unlike printing, puts it in a form that is not only readily accessible for very little cost, but a form that can easily be changed by the author or a reader. While one can more easily add highly effective graphics to digital documents compared to printing, ${ }^{205}$ one might find that these

${ }^{203}$ See FranCES CAIRNCROSS, THE DEATH OF DISTANCE: How THE COMMUNICATIONS REVOLUTION WILl CHANGE OUR LIVES (1997); KATSH, LAW IN A DIGITAL WORLD, supra note 10, at 218-19; MARGARET E. KECK \& KATHRYN SIKKINK, ACTIVISTSBEYOND BORDERS: ADVOCACY NETWORKS ININTERNATIONAL POLITICS (1998); TRANSNATIONAL SOCIAL MOVEMENTS AND GLOBAL POLITICS: SOLIDARITY BEYOND THE STATE (Jackıe Smith etal. eds., 1997); Jeffrey M. Ayres, From National to Popular Sovereignty? The Evolving Globalization of Protest Activity in Canada, 16 INT'LJ. CAN. STUD. 107 (1997); David R. Johnson \& David Post, Law and Borders-The Rise of Law in Cyberspace, 48 STAN. L. REV 1367 (1996); Lawrence Lessig, The Zones of Cyberspace, 48 STAN.L.REV 1403 (1996); Symposium, Law without Borders in the Information Age, 43 WAYNE L. REV 95 (1996).

${ }^{204}$ See generallyDAVIDBRIN, THE TRANSPARENT SOCIETY: WILL TECHNOLOGY FORCE US TO CHOOSE BETWEEN PRIVACY AND FREEDOM? (1998); BORDERS IN CYBERSPACE: INFORMATION POLICY AND THE GLOBAL INFORMATION INFRASTRUCTURE (Brian Kahin \& Charles Nesson eds., 1997); THOMAS L. FRIEDMAN, THE LEXUS AND THE OLIVE TREE: UNDERSTANDING GLOBALIZATION (1999); NiCHOLAS NEGROPONTE, BEING DigiTal (1995); Rosemary J. Coombe, Authortal Cartographtes: Mapping Propretary Borders in a Less-than-BraveNew World, 48 STAN. L. REV 1357 (1996); Walter A. Effross, Withdrawal of the Reference: Rights, Rules, and Remedies for Unwelcomed Web-Linking, 49 S.C.L. REV 651 (1998); Andy Johnson-Laird, The Anatomy of the Internet Meets the Body of the Law, 22 U. DAYTON L. REV 465 (1997); Johnson \& Post, supra note 203; Maureen A. O'Rourke, Fencing Cyberspace: Drawing Borders in a Virtual World, 82 MINN. L. REV 609 (1998); Joseph I. Rosenbaum, Prvacy on the Internet: Whose Information Is It Anyway?, 38 JURIMETRICS 565 (1998); Frederick Schauer, Internet Prvacy and the Public-Private Distinction, 38 JURIMETRICS 555 (1998).

${ }^{205}$ See KATSH, LAW IN A DIGITAL WORLD, supra note 10, at 133-71; Thomas R. Bruce, Swift, Modest Proposals, Bables, and Bathwater Are Hibbits's Writes Right?, 30 AKRON L. REV 243 (1996); Bernard J. Hibbits, Last Writes? ReAssessing the Law Review in the Age of Cyberspace, 71 N.Y.U. L. REV 615, 67071 (1996); Katsh, Rights, Camera, Action, supra note 86; Gregory E. Maggs, SelfPublication on the Internet and the Future of Law Revlews, 30 AKRON L. REV. 237 (1996); Henry H. Perritt, Jr., Reassessing Professor Hibbitts's Requiem for Law 
virtues are outweighed by the loss of control over the documents. The interactivity and hyperlinking possible on the Internet mean that a document is no longer fixed, uniform, and easily authenticated, as it would be in printed form. ${ }^{206}$ The transition from typewriter to word processor seemed so simple, the newer technology apparently emulating the older, that many schooled in the old technologies have overlooked the fundamental changes inherent in this transition. ${ }^{207}$ George Landow has summarized how this transforms our thinking as well as our reading:

Reviews, 30 AKRON L. REV 255 (1996); David A. Rier, The Future of Legal Scholarship and Scholarly Communication: Publication in the Age of Cyberspace, 30 AKRON L. REV 183 (1996).

${ }^{200}$ See JAY DAVID BOLTER, WRITING SPACE: THECOMPUTER, HYPERTEXT, AND THE HISTORY OF WRITING (1991); HYPER/TEXT/THEORY (George P Landow ed., 1994); KATSH, LAW IN A DIGITAL WORLD, supra note 10, at 92-113; ROSE, supra note 197; SCHOLARLY JOURNALS AT THE CROSSROADS: A SUBVERSIVE PROPOSAL FORELECTRONIC PUBLISHING (Ann Shumelda Okerson \& James J. O'Donnell eds., 1995); SCHOLARLY PUBLISHING: THE EleCtRONIC FRONTIER (Robin P Peek \& Gregory B. Newby eds., 1996); TEXT, CONTEXT, AND HYPERTEXT: WRITING WITH AND FOR THE COMPUTER (Edward Barrett ed., 1988); Jane C. Ginsburg, Putting Cars on the "Information Superhighway" Authors, Exploiters, and Copynght in Cyberspace, 95 CoLUM. L. REV 1466 (1995); Greenleaf et al., supra note 197; I. Trotter Hardy, Project CLEAR's Paper Choice: A Hypertext System for Giving Advice about Legal Research, 82 LAW LIBR. J. 209 (1990); Hibbitts, supra note 205; Katsh, Law Reviews, supra note 189, at 119; Lauritsen, supra note 197; Pamela Samuelson \& Robert J. Glusko, Electronic Communications and Legal Change: Intellectual Property Rights for Digital Library and Hypertext Publishing Systems, 6 HARV J. L. \& TECH. 237 (1993); Lauren H. Seiler, The Future of the Scholarly Journal, 74 MOD. LANGUAGE J. 1 (1990); Smith et al., supra note 197; Ronald W. Staudt, Legal Mindstorms: Lawyers, Computers and Powerful Ideas, 31 JURIMETRICS 171 (1991); McDonough, supra note 113; Shawn G. Pearson, Comment, Hype or Hypertext? A Plan for the Law Review to Move into the TwentyFirst Century, 1997 UTAH L. REV 765; Katie Hafner, Physics on the Web is Putting Science Journals on the Line, N.Y. TIMES, Apr. 21, 1998, at F3; David R. Johnson, Building and Using Hypertext Systems, LAW PRAC. MGMT., May-June 1991, at 28; Robert Pear, N.I.H. Plan for Journal on the Web Draws Fire, N.Y. TrMES, June 8, 1999, at F1.

${ }^{207}$ See Espen Aarseth, Nonlinearity and Literary Theory, in HYPER/TEXT/ THEORY, supra note 206, at 51, 52; see also GEORGEP. LANDOW, HYPERTEXT: THE CONVERGENCE OF CONTEMPORARY CRITICAL THEORY AND TECHNOLOGY 18-19 (1992); Collins \& Skover, supra note 1, at 510; Gamble, supra note 71, at 773-80; Ethan Katsh, Law in a Digital World: Computer Networks and Cyberspace, 38 VILL. L. REV 403, 443 (1993) [hereinafter Katsh, Computer Networks and Cyberspace]. 
Hypertext fragments, disperses, or atomizes text in two related ways. First, by removing the linearity of print, it frees the individual passages from one ordering priciple-sequence-and threatens to transform the text into chaos. Second, hypertext destroys the notion of a fixed unitary text. Considering the "entire" text in relation to its component parts produces the first form of fragmentation; considering it in relation to its variant readings and versions produces the second. ${ }^{208}$

Even such a hallowed system as how lawyers are educated is now under challenge as law schools and their regulatory institutions begin to consider the possibilities of "distance education" and other transformations. ${ }^{209}$ The nonlinearity of digital texts plays a central role here as well, promising dramatic changes to "the role of student, teacher, assignment, evaluation, reading list, as well as relations among individual instructors, courses, departments, and disciplines."210 How such changes will play out in the intellectual structure of the law, which tendencies will prevail, $^{211}$ and how these changes will affect what we have come to describe as the "rule of law,"

${ }^{208}$ LANDOW, supra note 207, at 54.

${ }^{209}$ See Katsh, Law Reviews, supra note 189; Beverly Tarpley, Keepıng Up with Technology, SYLlABUS, Winter 1998, at 8; see also John N. Hickman, Cybercheats: Term-Paper Shopping Online, NEW REP., Mar. 23, 1998, at 14.

${ }^{210}$ LANDOW, supra note 207, at 163.

${ }^{211}$ See Gordon Bermant, Courting the Virtual: Federal Courts in an Age of Complete Inter-Connectedness, 25 OHIO N.U. L. REV 527 (1999); Paul J. Johns, Changing Traditional Education; and Creating New Judicial Responsibilities, 25 OHIO N.U. L. REV 569 (1999); Joseph F Weiss, Jr. \& Gordon Bermant, Automation in the Federal Courts: Progress, Prospects, and Problems, JUDGES J., Fall 1987, at 14.

${ }^{212}$ See ROBERT M. COVER, JUSTICE ACCUSED: ANTISLAVERY ANDTHEJUDICIAL PROCESS (1975); JOSEPH RAZ, THE AUTHORITY OF LAW· ESSAYS ON LAW AND MORALITY 211-26 (1979); WHITE, JUSTICE AS TRANSLATION, supra note 68; Bobby R. Baldock, Justice and the Rule of Law: A Contradiction in Terms?, $15 \mathrm{~S}$. ILL. U. L.J. 57 (1990); Blum, supra note 68; Hilary Charlesworth et al., Feminust Approaches to International Law, 85 AM.J.INT'LL. 613 (1991); Cover, supra note 68; Lynne Henderson, Authoritarzanzsm and the Rule of Law, 66 IND. L.J. 379 (1990); Martin Krygier, Marxism and the Rule of Law, 15 LAW \& SOC. INQUIRY 633 (1990); Ton1 M. Massaro, Empathy, Legal Storytelling, and the Rule of Law: New Words, Old Wounds?, 87 Mich. L. REV 2099 (1989); Carne MenkelMeadow, Excluded Voices: New Voices in the Legal Profession Makng New Vouces in the Law, 42 U. MIAMIL.REV.29 (1987); Frank I. Michelman, Foreword: Traces of Self-Government, 100 HARV L. REV 4 (1986); Martha Minow, 
from the earliest responses, law and society seem once again to be decentralizıng power and dispute resolution. ${ }^{213}$ Another way of describıng this change is to note a trend toward relying on private solutions to social issues in the "virtual world." 214

Foreword: Justice Engendered, 101 HARV L. REV 10 (1987); Margaret Jane Radin, Reconsidering the Rule of Law, 69 B.U. L. REV 781 (1989); Smith, supra note 68; Symposium, Transitions to Democracy and the Rule of Law, 5 AM. U. J. INT'L L. \& POL'Y 965 (1990); Laurence H. Tribe, Revtsiting the Rule of Law, 64 N.Y.U.L. REV 726(1989); West, Jurzprudence and Gender, supra note 68; Klaus A. Ziegert, Courts and the Self-concept of Law: The Mapping of the Environment by Courts of First Instance, 14 SYDNEY L. REV 196 (1992).

${ }^{213}$ See COMPARATIVE PERSPECTIVES ON SOCIAL MOVEMENTS: POLITICAL OPPORTUNITIES, MOBILZING STRUCTURES, AND CULTURAL FRAMINGS (Doug McAdam et al. eds., 1996); COUNCIL OF EUROPE, DISILlUSIONMENT WITH DEMOCRACY: POLITICAL PARTIES, PARTICIPATION AND NON-PARTICIPATION IN DEMOCRATIC INSTTUUTIONS IN EUROPE (1994); LAWRENCE K. GROSSMAN, THE ELECTRONIC REPUBLIC: RESHAPING DEMOCRACY IN THE INFORMATION AGE (1995); JÜRGEN HABERMAS, THE STRUCTURAL TRANSFORMATION OF THE PUBLIC SPHERE: AN INQUIRY INTO A CATEGORY OF BOURGEOIS SOCIETY (1989); THE STATE OF THE PARTIES: THE CHANGING ROLE OF CONTEMPORARY AMERICAN PARTIES (John C. Green \& Daniel M. Shea eds., 3d ed. 1999); MARTIN P WatTEnBerg, The RISE of CANDIDATE-CENTEREd Politics: Presidential ElECTIONS OF THE 1980S (1991); John H. Aldrich, Political Parties in a Critical Era, 27 AM. POL. Q. 9 (1999); Jeffrey M. Ayres, From the Streets to the Internet: The Cyber-Diffusion of Contention, 566 ANNALS AM. ACAD. POL. \& SoC. SCI. 132 (1999); Bruce Bimber, The Internet and Political Transformation: Populism, Community, and Accelerated Pluralism, 31 PoLITY 133 (1998); Robert L. Dunne, Deterring Unauthorized Access to Computers: Controlling Behavior in Cyberspace Through a Contract Law Paradigm, 35 JURIMETRICS 1 (1994); I. Trotter Hardy, The Proper Legal Regime for "Cyberspace," 55 U. PITT. L. REV 993 (1994); David R. Johnson \& Kevin A. Marks, Mappıng Electronic Data Communications onto Existing Legal Metaphors: Should We Let Our Consclence (and Our Contracts) Be Our Gulde?, 38 VILL. L. REV 487 (1993); Hank Johnston \& Shoon Lio, Looknng Backward to Look Forward, 41 SOC. PERSP 453 (1998); Henry H. Perritt, Jr., Dispute Resolution in Electronic Network Communities, 38 VILL. L. REV 349 (1993); Joel R. Reidenberg, Governing Networks and Rule-Making in Cyberspace, 45 EMORYL.J.911 (1996); R.A.W. Rhodes, The Hollowing Out of the State: The Changing Nature of the Public Service in Britain, 65 POL. Q. 138 (1994); Sidney .Tarrow, Social Movements in Contentious Politics: A Review Article, 90 AM. POL. SCI. REV 874 (1996); Matthew J. Feeley, Note, EU Internet Regulation Policy: The Rise of Self-Regulation, 22 B.C. INT'L \& COMP L. REV 159 (1999).

${ }^{214}$ See Carole M. Rose, The Several Features of Property: Of Cyberspace and Folk Tales, Emission Trades and Ecosystems, 83 MINN. L. REV 129, 130 (1998); 
The resulting social and legal decentralization in some ways is reminiscent of the village culture characteristic of oral and even scribal law, which has given rise to the inherently contradictory expression "global village" to describe the emerging culture and, at least by implication, its law ${ }^{215}$ Whether we shall ever truly get to the situation of "legal pluralism" once so charactenstic of oral and scribal law remains to be seen. ${ }^{216}$ The one

see also Julian Dibbell, $A$ Rape in Cyberspace or How an Evil Clown, a Haitian Trickster Spirit, Two Wizards, and a Cast of Dozens Turned a Database into a Society, 2 ANN. SURV AM. L. 471 (1994); Mark L. Gordon \& Diana J.P McKenzie, A Lawyer's Roadmap of the Information Superhighway, $13 \mathrm{~J}$. MARSHALL J. COMPUTER \& INFO. L. 177 (1995); Lessig, supra note 16; Oedel, supra note 88; Peter P Swire, Of Elephants, Mice, and Privacy: International Choice of Law and the Internet, 32 INT'L LAW. 991 (1998). But see Frank H. Easterbrook, Cyberspace and the Law of the Horse, 1996 U. CHI. LEGALF 207; Jack L. Goldsmith, Against Cyberanarchy, 65 U. CHI. L. REV 1199 (1998).

${ }^{215}$ See RICHARD A. FALK, LAW IN AN EMERGING GLOBAL VILLAGE: A POSTWESTPHALIAN PERSPECTIVE (1998); Lucian Arye Bebchuck \& Mark J. Roe, $A$ Theory of Path Dependence in Corporate Ownership and Governance, 52 STAN. L. REV 127, 134 (1999); Seth F Berkley, AIDS in the Global Village: Why U.S. Physicians Should Care about HIV outside the United States, 268 JAMA 3368 (1992); Barry Fnedman, Federalism's Future in a Global Village, 47 VAND. L. REV 1441 (1994); Justine Levine, A History and Analysis of the Federal Communtcations Commussion's Response to Radio Broadcast Hoaxes, 52 FED. COMM. L.J. 273 (2000); David A. Martin, New Rules on Dual Nationality for a Democratizing Globe: Between Rejection and Embrace, 14 GEO. IMM. L.J. 1, 5 (1999); G. Edward White, Observations on the Turning of Foreign Affairs Jurnsprudence, 70 U. COLO. L. REV 1109, 1122 (1999); Jitka Smith, Comment, Budweiser or Budweiser?, 32 J.MARSHALLL.REV 1251, 1258, 1278 (1999); Irvin Molotsky, Chernobyl and the "Global Village,"N.Y. TIMES, May 8, 1986, at B22.

${ }^{216}$ See HAROLD J. BERMAN, LAW AND REVOLUTION: THE FORMATION OF THE WESTERN LEGAL TRADITION (1983); PAUL VINOGRADOFF, ROMAN LAW IN MEDIEVAL EUROPE (1929); see also THOMAS B. STEVENS, ORDERANDDISCIPLINE IN CHINA.THESHANGHAIMIXEDCOURT 1911-1927(1992); P.E.B. Coy, Justice for the Indian in Eighteenth Century Mexico, 12 AM. J. LEGAL HIST. 41 (1968).

For contemporary appeals for legal pluralism, see ANNE HELLUM, WOMEN'S HUMANRIGHTS AND LEGAL PLURALISM IN AFRICA. MIXEDNORMS AND FERTILITY MANAGEMENT IN ZIMBABWE (1997); M.B. HOOKER, LEGAL PLURALISM: AN INTRODUCTION TO COLONIALAND NEO-COLONIAL LAWS (1975); Marc Galanter \& David Luban, Poetic Justice: Punitive Damages and Legal Pluralism, 42 AM. U. L. REV 1393 (1993); Richard D. Garcia \& Todd Howland, Determining the Legitimacy of Spanish Land Grants in Colorado: Conflicting Values, Legal Pluralism, and Demystification of the Sangre de Cristo/Rael Cases, 16 CHICANOLATINO L. REV. 39 (1995); John Griffiths, What Is Legal Pluralism?, 24 J. LEGAL 
thing we can be certain of is that the forms of law with which we are familiar are already passing from the scene.

Thus far, only a few countries have attempted to exert control over the emerging "electronic village." The most notable example is China, where the government has attempted to impose tight restrictions on who can use the Internet and for what purposes. ${ }^{217}$ The Chinese government has even charged entrepreneur Lin Ha1 with "inciting subversion of state power" for the unauthorized provision of e-mail addresses to "hostile foreign publications." ${ }^{218}$ Actually controlling the movement of information through the Internet might prove to be a hopeless effort, as even China could find that it lacks the resources to police the near infinite volume of messages and information easily transmitted around the barners it is attempting to impose upon Internet traffic. ${ }^{219}$ China, after all, has only recently undertaken to enter into the age of printed law ${ }^{220}$ Proposed technological

PLURALISM \& UNOFFICIAL L. 1 (1986); Benjamin A. Kahn, The Legal Framework Surrounding Maon Claims to Water Resources in New Zealand: In Contrast to the American Indian Expertence, 35 STAN. J. INT'L L. 49 (1999); Sally Engle Merry, Legal Pluralism, 22 LAW SOC'Y REV 869 (1988); Andrea M. Seielstad, Unwritten Laws and Customs, Local Legal Cultures, and Clinical Legal Education, 6 CLINICAL L. REV 127 (1999); Brian Tamanaha, The Folly of the "Social Sclentific" Concept of Legal Pluralism, 20 J. LAW \& SoC'Y 192 (1993); Gunther Teubner, The Two Faces of Janus: Rethinkang Legal Pluralism, 13 CARDOZO L. REV 1443 (1992).

${ }^{217}$ See David Bachman, Succession Politics and China's Future, 49 J. INT'L AFF. 370,379-80, 382-83 (1996); Peter Ferdinand, Social Change and the Chinese Communist Party: Domestic Problems of Rule, 49 J. INT'L AFF 478 (1996); Dali L. Yang \& Houkai We1, Rising Sectionalism in China, 49 J.INT'LAFF.456(1996); Elisabeth Rosenthal, China Lusts Controls to Restruct the Use of E-Mail and Web, N.Y. TIMES, Jan. 27, 2000, at Al; see also STEWART BAKER \& PAUL HURST, THE LIMITS OF TRUST 130 (1998); A. Michael Froomkın, The Metaphor Is the Key: Cryptography, the Clipper Chip, and the Constitution, 143 U. PA. L. REV 709 (1995); Amy Knoll, Comment, Any Which Way but Loose: Nations Regulate the Internet, 4 TUL. J. INT'L \& COMP L. 275 (1996).

${ }^{218}$ Erik Eckholm, $A$ Trial Will Test China's Grip on the Internet, N.Y. TIMES, Nov. 16, 1998, at A8. The addresses were used by democracy advocates based in the United States to e-mail articles into China; Mr. Lin claims that he was only exchanging addresses so he could build his e-mail business.

${ }^{219}$ See generally Froomkın, supra note 86; M. Ethan Katsh, Software Worlds and the First Amendment: Virtual Doorkeepers in Cyberspace, 1996U. CHI. LEGAL F 335 [hereinafter Katsh, Software Worlds]; Eugene Volokh, Cheap Speech and What It Will Do, 104 YALE L.J. 1805 (1995).

${ }^{220}$ See generally CONTRACT, GUANXI, AND DISPUTE RESOLUTION IN CHINA (Tahirih V.Lee ed., 1997); DOMESTICLAW REFORMS INPOST-MAOCHINA(Pitman 
controls over Web access might eventually succeed, but at a cost beyond the simple expense of introducing the necessary technology ${ }^{221}$ If China succeeds in controlling the flow of information over the Web, it can only do so by severely limiting the utility of Cyberspace for the Chinese economy, Chinese academics, and Chinese society-precisely theopposite of what the Chinese government itself hopes to achieve through access to the Web. 22

\section{B. How International Law is Affected by the Changing Forms of Law}

The foregoing analysis describes, admittedly in highly general terms, the successive transformations wrought in national legal systems by basic changes in communications technologies. One of the enduring problems in international law is that in many ways it remains a primitive legal system, still functioning largely in the scribal mode. ${ }^{223}$ While the legal sources were usually fixed in written form, the materials were often difficult even to locate, let alone to read and interpret correctly As a result, until very

B. Potter ed., 1994); RONALDC.KEITH, CHINA's STRUGGLE FOR THERULE OF LAW (1994); LAW, THE STATE, AND SOCIETY IN CHNA (Tahırih V Lee ed., 1997); CARLOS WING-HUNG LO, CHINA'S LEGAL AWAKENING: LEGAL THEORY AND CRIMINAL JUSTICE IN DENG's ERA (1995); Joseph W Dellapenna, The Role of Legal Rhetornc in the Failure of Democratic Change in China, 2 BUFF. J. INT'L L. 231 (1996); Jun Ge, Mediation, Arbitration and Litigation: Dispute Resolution in the People's Republic of Chma, 15 UCLA PAC. BASIN L.J. 122 (1996); Chin Kim, The Modern Chinese Legal System, 61 TUL. L. REV 1413 (1987); Stanley B. Lubman, Dispute Resolution in China after Deng Xiaoping: "Mao and Mediation" Revisited, 11 COLUM.J. AsIAN L. 229 (1997); Daniel C. Turack, The New Chinese Criminal Justice System, 7 CARDOzo J. INT'L \& COMP L. 49 (1999); Ding Xueliang, The Orzin and Conceptual Development of "Modernization" Theory, ZHONGGUO SHEHUI KEXUE, Jan. 1988, at 65 (in Chunese); Jiang Xun, The Modernization of China's Legal Culture, 7 FAXUE 12 (1987) (in Chınese).

${ }^{221}$ See LAWRENCE LESSIG, CODE AND OTHER LAWS OF CYBERSPACE (1999); Julie E. Cohen, Some Reflections on Copyright Management Systems and Laws Designed to Protect Them, 12 BERKELEY TECH. L.J. 161 (1997); Katsh, Software Worlds, supra note 219; Lawrence Lessig, What Things Regulate Speech: CDA 2.0 vs. Filtering, 38 JURIMETRICS 629 (1998); Joel R. Reidenberg, Lex Informatica: The Formulation of Information Policy Rules through Technology, 76 TEX.L. REV 553 (1998); Semitsu, supra note 145; Jonathan Weinberg, Rating the Net, 19 HASTINGS COMM. \& ENT. L.J. 453 (1997).

${ }^{222}$ See China's Biggest Website to Be Lusted Overseas, BEIJING REV., Nov. 13, 1999, at 26; Greeting an E-Business Era, supra note 11.

${ }^{223}$ See supra notes 170-185 and accompanying text. 
recently the international lawyers fixed their focus firmly on customary law. ${ }^{224}$ Like customary (oral) law generally, international law remained flurd and highly contextual, ${ }^{225}$ despite the glimmerings of pretension to universal norms. ${ }^{226}$

Only within this century has the international legal order begun to adopt fully the forms approprate to printed law, with multilateral treaties, ${ }^{227}$ formal judicial opinions, ${ }^{228}$ and devices for making "custom" consciously and concretely ${ }^{229}$ One commentator noted these changes and

${ }^{224}$ See ANTHONY A. D'AMATO, THE CONCEPT OF CUSTOM IN INTERNATIONAL LAW (1971); KELSEN, supra note 160, at 311-13; Michael Akehurst, Custom as a Source, of International Law, 47 BRIT. Y.B. INT'LL. 1 (1977).

${ }^{225}$ See Christine Chinkın \& Romana Sadurska, The Anatomy of International Dispute Resolution, 7 OHIO ST. J. DISP RESOL. 1 (1991); Dellapenna, Jordan Valley, supra note 108; I. William Zartman, Conflict and Resolution: Contest, Cost, and Change, 518 ANNALS OF AM. ASS'N POL. \& SoC. SCI. 11 (1991).

${ }^{226}$ See FRANCK, supra note 151, at 147-53; Boyle, supra note 152, at 349-52.

${ }^{227}$ See ANTHONY A. D'AMATO, INTERNATIONAL LAW:PROCESS AND PROSPECT 123-25 (1987); R.R. Baxter, Multilateral Treaties as Evidence of Customary International Law, 41 BRT. Y.B. INT'L L. 275 (1968).

${ }^{228}$ See Mohammed Bedjaoul, The "Manufacture" of Judgments at the International Court of Justice, 3 PACE Y.B. INT'L L. 29 (1991); Giorg1o Bosco, New Trends on Peaceful Settlement of Disputes between States, 16 N.C. J. INT'L L. \& COM. REG. 235 (1991); Jonathon I. Chamey, Customary International Law in the Nicaragua Case: Judgment on the Merits, 1988 HAGUE Y.B. INT'L L. 16; Keith Highet, The Peace Palace Heats Up: The World Court in Business Again?, 85 AM. J. INT'L L. 646 (1991); José Maria Ruda, Some of the Contributions of the International Court of Justice to the Development of International Law, 24 N.Y.U. J. INT'L L. \& POL. 35 (1991); David J. Scheffer, Non-Judiclal State Remedies and the Jurisdiction of the International Court of Justice, 27 STAN. J. INT'L L. 83 (1990).

The International Court of Justice bases its decisions on custom (including general principles of law) or treaty-based law, and not on its own decisions except as evidence of the primary sources. See Statute of the International Court of Justice [hereinafter ICJ Statute], art. 38, opened for signature June 26, 1945, 59 Stat. 1055 (entered into force Oct. 24, 1945).

${ }^{229}$ See R.P.DHOKALIA, CODIFICATIONOF PUBLICINTERNATIONALLAW (1970); H.W.A. THIRLWAY, INTERNATIONAL CUSTOMARY LAW AND CODIFICATION(1972); Danilenko, supra note 31, Hersch Lauterpacht, Codification and Development of International Law, 49 AM. J. INT'L L. 16 (1955); Oscar Schachter, International Law in Theory and Practice, 178 RECUEIL DES COURS 9 (1982); Paul C. Szasz, The Role of the U.N. Secretary-General: Some Legal Aspects, 24 N.Y.U. J. INT'L L. \& PoL. 161 (1991); Phillip R. Trumble, A Revisionist View of Customary International Law, 33 UCLA L. REV 665 (1986). 
described them as a trend toward the creation of a lex scrpta, ${ }^{230}$ including such mechanisms as UN General Assembly ${ }^{231}$ resolutions or International Law Commission studies ${ }^{232}$ as devices for making customary law more fixed and promptly retrievable. While the language of customary law continues, increasingly that language is more of a legal fiction than an accurate description of how international law functions. ${ }^{233}$ Before this process has been completed, we are confronted with a typical paratextual demand that international law be reconcerved as an open-ended conversation, an uncoerced discourse, that will bind disputants together in their commitment to resolve therr mutual problems through imagining new ways to cope with social conflict. ${ }^{234}$

Those of us who practice international law need to attend more to the implications of the interactive process between means, ends, and intellectual structures if we are to better control, or even merely better respond to, the processes transforming the world in which we live. ${ }^{235}$ To understand and to manage this intersection of law with science and technology, we need both to reconfigure our means for collecting and analyzing our knowledge of scientific concepts and the technologies reshaping the world even while we reconsider the institutions for decision-makung appropriate

${ }^{230}$ See THIRLWAY, supra note 229, at 1-16; see also ARTHUR NUSSBAUM, A CONCISE HISTORY OF THE LAW OF NATIONS 235 (1947).

${ }^{231}$ See R.S. Gupta, Resolutions of the United Nations General Assembly as a Source of International Law, 23 INT'L STUD. 143 (1986); Christopher C. Joyner, U.N. General Assembly Resolutions and International Law: Rethinking the Contemporary Dynamics of Norm-creation, 11 CAL. W INT'L L.J. 445 (1981).

${ }^{232}$ See B.G. RAMCHARAN, THE INTERNATIONAL LAW COMMISSION: ITS APPROACH TO THE CODIFICATION AND PROGRESSIVE DEVELOPMENT OF INTERNATIONAL LAW (1977); IAN SINCLAIR, THE INTERNATIONAL LAW COMMISSION (1987); B. Graefrath, The International Law Commission Tomorrow: Improving Its Organization and Methods of Work, 85 AM. J. INT'L L. 595 (1991).

${ }^{233}$ See KENNEDY, supra note 152, at 39; Allott, supra note 151, Baxter, supra note 227; Hiram E. Chodosh, Neither Treaty nor Custom: The Emergence of Declarative International Law, 26 TEX. INT'L L.J. 87 (1991); Gamble, supra note 71, at 781-86; Schachter, supra note 229.

${ }^{234}$ See, e.g., KOSKENNIEMI, supra note 152, at 486-501, see also CARTY, supra note 28, at 113-15; KENNEDY, supra note 152; Trask, supra note 120.

235 The problem of means-ends flurdity is a long-standing and farly commonplace topic of discussion in the philosophy of ethics. See, e.g., Morton A. Kaplan, Means/Ends Rationality, 87 ETHICs 61 (1976); see also Johnston, supra note 151. 
to our increasingly interdependent and technologized world. ${ }^{236}$ Only by attending to the intellectual structures as well as to the material conditions of the decision-maknng processes can we hope to make reasonably appropriate decisions in the face of the pervasive uncertainty generated by the rapid changes in science and technology 237

Revising our decision-making processes will include the creation of transnational facilities for gathering and assessing information, for coordinating policies and laws, and resolving disputes. Yet, by far the most interesting and important aspect of the overall process of interaction between law and technology is the structural alteration of the law itself, challengng our received conceptions of the international community that is the subject of that law Durng the penod of state-centered legal theory, international lawyers have had to contend with the question of whether international law really is law. ${ }^{238}$ Today, as the deconstruction project decenters the state in municipal law, ${ }^{239}$ modern technology has also radically reduced the importance of the traditional nation-state, ${ }^{240}$ although

${ }^{236}$ See Allott, supra note 151, Harold J. Berman, Toward an Integrative Jursprudence: Politics, Morality, History, 76 CAL. L. REV 779 (1988); Seyom Brown \& Larry L. Fabian, Toward Mutual Accountability in the Nonterrestrial Realms, 29 INT'L ORG. 877 (1975); Gamble, supra note 71, F V Garciá-Amador, Current Attempts to Revise International Law-A Comparative Analysis, 77 AM. J. INT'L L. 286 (1983); Ernst B. Haas, Is There a Hole in the Whole? Knowledge, Technology, Interdependence and the Construction of International Regrmes, 29 INT'LORG. 827 (1975); Edward McWhinney, The Need for a New General Theory of International Law, 23 CAN. Y.B. INT'L L. 311 (1985); see also WILLIAM J. KAUFMAN III \& LARRY L. SMARR, SUPERCOMPUTING AND THE TRANSFORMATION OF SCIENCE (1993).

${ }^{237}$ See PETER WILLIAM HUBER, GALILEO'S REVENGE: JUNK SCIENCE IN THE COURTROOM (1993); Allott, supra note 151, Victor Baker, Uncertainty and Tolerance in Science and Decisionmaking, 9 ARIZ.J.INT'L \& COMP.L. 253 (1992); Donald T. Hornstem, Reclaiming Environmental Law: A Normative Critique of Comparative Risk Analysus, 92 COLUM. L. REV 562 (1992); Zhou Dadi, Environmental Considerations in the Economic Development of China, 9 ARIZ. J. INT'L \& COMP L. 221 (1992).

${ }^{238}$ See supra note 163 and accompanyıng text.

${ }^{239}$ See supra note 42 and accompanying text.

${ }^{240}$ See RoBERT A. FALK, LAW IN AN EMERGING GLOBAL VILLAGE: A POSTWESTPHALIAN PERSPECTIVE (1998); ROBERT H. JACKSON, QUASI-STATES: SOVEREIGNTY,INTERNATIONALRELATIONS, AND THE THIRD WORLD(1990); L.ALI KHAN, THE EXTINCTIONOF NATION-STATES: A WORLD WTTHOUT BORDERS(1996); WALTER B. WRISTON, THE TWILIGHT OF SOVEREIGNTY: HOW THE INFORMATION REVOLUTIONIS TRANSFORMING OUR WORLD(1992); Mark W. Janıs, International 
the systems that will replace the nation-state remain far from clear. ${ }^{241}$ Some will see in the disintegration of recerved theory, flawed as it might have been, a decline of international law into disarray ${ }^{242}$ Given the problems international legal theory suffered in the face of the theory of the allsovereign state, however, international law actually seems more firmly fixed as law with the deconstruction of the state, ${ }^{243}$ although some better name might have to be agreed upon for the field. ${ }^{244}$

Like all law, international law is more than just a conversation. ${ }^{245} \mathrm{Law}$ involves coercion, however undeveloped its institutional structure might be. ${ }^{246}$ Yet, it is not coercion that makes a body of discourse into law but the

Law?, 32 HARV. INT'L L.J. 363 (1991); Kanıshka Jayasuriya, Globalization, Law, and the Transformation of Soveretgnty: The Emergence of Global Regulatory Governance, 6 IND. J. GLOBAL LEG. STUD. 425 (1999); Karsten Nowrot, Legal Consequences of Globalization: The Status of Non-Governmental Organizations under International Law, 6 IND. J. GLOBAL LEG. STUD. 579 (1999); Bryan L. Walser, Shared Technical Decisionmakng and the Disaggregation of Sovereignty: International Regulatory Policy, Expert Communities, and the Multinational Pharmaceutical Industry, 72 TUL. L. REV 1597 (1998).

${ }^{241}$ See CARTY, supra note 28; Allott, supra note 151; Alfred C. Aman, Jr., Proposals for Reforming the Administrative Procedure Act: Globalization, Democracy and the Furtherance of a Global Public Interest, 6 IND. J. GLOBAL LEG. STUD. 397 (1999); Benjamin R. Barber, Three Scenarnos for the Future of Technology and Strong Democracy, 113 POL. SCI. Q. 573 (1999); Dueling Globalizations: A Debate between Thomas L. Fredman and Ignacio Ramonet, 116 FOR. POL'Y 110 (1999); Jack L. Goldsmith, The Internet and the Abuding Significance of Territoral Sovereegnty, 5 IND. J. GLOBAL LEGAL STUD. 475 (1998); Stephen Haggard \& Beth A. Simmons, Theores of International Regimes, 41 INT'LORG. 491 (1987); Miguel de la Madrid Hurtado, Foreword: National Soveretgnty and Globalization, 19 HoUS. J. INT'L L. 553 (1997); Henry H. Perritt, Jr., The Internet as a Threat to Sovereignty' Thoughts on the Internet's Role in Strengthening National and Global Governance, 5 IND. J. GLOBAL LEGAL STUD. 423 (1998); Stephen D. Krasner, Structural Causes and Regime Consequences: Regimes as Intervening Vanables, 36 INT'L ORG. 185 (1982).

${ }^{242}$ See Johnston, supra note 151, at 3; Kenneth $\mathrm{L}$. Wise, Social Science and Global Law, 14 CREIGHTON L. REV 1355 (1981).

${ }^{243}$ See TERRY NARDIN, LAW, MORALITY, AND THERELATIONS OF STATES 12133 (1983); MacLean, supra note 151.

${ }^{244}$ On the displacement of the older term "law of nations" with the term "international law," see M.W Janıs, Jeremy Bentham and the Fashioning of "International Law," 78 AM.J.INT'LL.405 (1984); see also Janis, supra note 240. ${ }^{245}$ See WHITE, JUSTICE AS TRANSLATION, supra note 68, at 257-69.

${ }^{246}$ See CARTY, supra note 28, at 28-37; Nicholas Onuf, Do Rules Say What They Do? From Ordinary Language to International Law, 26 HARV.INT'LL.J.385 
adherence to that body as law by the community whose ideas the laws propose to regulate. ${ }^{247}$ Only because a norm is considered to be legitımately obligatory is the coercion attached to the norm both accepted in a society and effective beyond the reach of the initial lawgiver. ${ }^{248}$

Nowhere is the normative power of the idea of law more clear than in the workings of the International Court of Justice-a court before which litigants appear voluntarily or not at all. ${ }^{249}$ To make these arrangements more effective we must begin to redesign such institutions to make them more responsive to our emerging global needs. ${ }^{250}$ Only as we begin to make more accommodations to the realities created by science and technology can we begin to build a world of peaceful and effective environmental management that will begin to meet the needs of all peoples for dignity, security, and well-being.

\section{CONCLUSION}

The examples described in this Article suggest that science and technology have affected international law profoundly in several ways:

(1) Science, and more particularly technology, changes the problems that international law must address (ends alteration);

(2) Science, and more particularly technology, changes the range of responses available for problems confronted by international law (means alteration); and

(3) Science and technology change the intellectual structures that make up legal thinking in general and international law in particular, and thus, in the end, alter the nature and functions of international law even when the means and ends as such are not affected by scientific or technological changes (structural alteration).

(1985).

${ }^{247}$ See FRANCK, supra note 151, at 24, 184-90, 194.

${ }^{248}$ See A.L. GOODHART, ENGLISH LAW AND THE MORAL LAW 17 (1988).

${ }^{249}$ See ICJ Statute, supra note 228, at arts. 36, 37

${ }^{250}$ See THE INTERNATIONAL COURT OF JUSTICE AT A CROSSROADS (Lon Fisler Damrosch ed., 1987); THOMAS M. FRANCK, JUDGING THE WORLD COURT (1986); ELIHU LAUTERPACHT, ASPECTS OF THE ADMINISTRATION OF INTERNATIONAL JUSTICE (1991); SHABTAI ROSENNE, THE WORLD COURT: WHAT IT IS AND HOW IT WORKS (3d ed. 1973) (1962); Abraham D. Sofaer, Adjudication in the International Court of Justice: Progress through Realism, 44 REC. Ass'N B. CITY N.Y. 462 (1989); see also Lockerbie (Libya v. U.S.), reprinted in 86 AM. J. INT'L L. 638 (1992) (I.C.J. Apr. 14, 1992); Trask, supra note 120. 
I do not intend by this analysis to suggest that science and technology directly control the evolution of international law. After all, the persistence of scribal forms in international law long after printing revolutionized national legal systems disproves any simple deterministic view of how science and technology affects law Rather, technology forms one axis whose intersection with the other, political or normative axis, reshapes everything we as international lawyers do. ${ }^{251}$ These effects give concrete expression to the vague notion that increasingly we live in a global village, ${ }^{252}$ or, as John Ruggie aptly summanzed the point, "we are, for the first time, living in a single history $" 2253$

The challenges posed by the emerging new social forms are daunting, to say the least. Ethan Katsh, perhaps our most thoughtful commentator regarding where the new electronic information and communications technologies are takıng us, ${ }^{254}$ has expressed the problems we will face by recounting the story of anthropologist Edward Hall. ${ }^{255}$ It seems that Hall came back to his hotel in Japan one evening to find someone else occupying his room. Upon inquiring at the front desk, he found that his room had been moved without his knowledge or consent. Going to the new room, he found that all of his possessions had been lard out in the new room in a nearly identical pattern to the way he had left them in the morning, and that the room itself strongly resembled the room from which he had been moved. Needless to say, Hall found this very discomfiting. Later, Hall would learn that this moving was a sign of respect-that he was "being treated as a family member"-a relationship in which one can afford to be "relaxed and informal and not stand on ceremony ${ }^{3256}$ What is important, however, is that the expenence- quite different from anything that he had experienced in his own culture, was senously disonenting. Hall realized that he was now operating in a culture that he did not fully understand despite the apparent familiarity of virtually every physical detail of the environment in which that culture operated. His long-held assumptions about the relationship between a guest and a hotel did not hold, and he no

${ }^{251}$ See John Gerard Ruggie, International Responses to Technology: Concepts and Trends, 29 INT'L ORG. 557, 558 (1975).

${ }^{252}$ See supra note 215 and accompanying text.

${ }^{253}$ Ruggie, supra note 251 , at 557

${ }^{254}$ See KATSH, LAW IN A DIGITAL WORLD, supra note 10; KATSH, ELECTRONIC MEDIA, supra note 16.

${ }^{255}$ See Katsh, Computer Networks and Cyberspace, supra note 207, at 468-70 (referring to two similar stories that Hall recounts in EDWARDHALL, THE HIDDEN DIMENSION (1969)).

${ }^{256}$ HALL, supra note 255, at 65. 
longer knew what the rules were. As Katsh summanzed it, "[w] hat was his, what was shared, and what belonged to others were no longer as clear as they had been. .2257

The message Katsh would have us draw from this story is that as we enter into a world of digital law, we also enter a new cultural setting in which everything looks familiar but which none of us can take for granted. The boundaries between ourselves and others, between ours and theirs, no longer hold. We must reexamine our assumptions and learn anew how to behave appropnately and effectively If we neglect this lesson, we will simply be left behind, like the blacksmith who, a century ago, refused to learn auto mechanics.

${ }^{257}$ Katsh, Law Reviews, supra note 189, at 116. 
